\title{
Medusa: Um ambiente musical distribuído
}

\author{
Flávio Luiz Schiavoni
}

TESE APRESENTADA

AO

Instituto DE Matemática e Estatística

DA

Universidade De SÃo Paulo

PARA

OBTENÇÃO DO TÍTULO

$\mathrm{DE}$

Doutor EM CIÊNCIAS

Programa: Doutorado em Ciência da Computação

Orientador: Prof. Dr. Marcelo Gomes de Queiroz

Durante o desenvolvimento deste trabalho o autor recebeu auxílio financeiro da CAPES/CNPq

São Paulo, Dezembro de 2013 



\section{Medusa: Um ambiente musical distribuído}

Esta versão da tese contém as correções e alterações sugeridas pela Comissão Julgadora durante a defesa da versão original do trabalho, realizada em 17/12/2013. Uma cópia da versão original está disponível no Instituto de Matemática e Estatística da Universidade de São Paulo.

Comissão Julgadora:

- Prof. Dr. Marcelo Gomes de Queiroz (orientador) - IME-USP

- Prof. Dr. Marcelo Mortensen Wanderley - McGill University

- Prof. Dr. Fernando Henrique de Oliveira Iazzetta - ECA-USP

- Prof. Dr. Daniel Macêdo Batista - IME-USP

- Prof. Dr. Alfredo Goldman vel Lejbman - IME-USP 



\section{Agradecimentos}

Em 2010 fui aceito no doutorado na área de Computação Musical pelo professor Marcelo Queiroz do Instituto de Matemática e Estatística da Universidade de São Paulo. O Queiroz não só aceitou me orientar como concordou em me orientar em uma pesquisa sobre música em rede. Quase não pude acreditar na existência de um orientador assim. Aqui começa uma história.

Saí de Maringá para fazer meu doutorado deixando para trás minha família, amigos, meu emprego de professor na UEM, na FAFIMAN, meu estúdio e também minha banda de rock. Não é fácil para um caipira sair do interior. Meu pai Adélcio e minha mãe Vildair sofreram este doutoramento à distância. Nesta ocasião eu fui morar com um amigo de infância, Giuliano Obici, baterista da minha primeira banda de rock nos idos de 93, que estava se doutorando em música na ECA. O Giu já morava em Sampa e me arrumou um quarto na casa dele. Conosco foi morar outro músico e doutorando, um colombiano chamado Julian Jaramillo. Começava a chamar São Paulo de lar.

Aqui, conheci Cassi Ane Pinheiro e a vida passou a fazer mais sentido. Com ela veio a família dela que topou ser minha família também. Tania, Moacyr, Omara, Clari, Jean, Lali, Mel, Rael, Ana.

Mesmo com outra família, a saudades de casa nunca acabou. Culpa dos meus irmãos André e Marcos e de minhas cunhadas Lu e Pati que me deram quatro dos mais lindos sobrinhos do mundo: Bruno, Vitor Hugo, Lívia e Gabriel.

Na USP, com a orientação do Queiroz, veio todo um grupo de pesquisa em computação musical do IME e um grupo de pesquisa com o pessoal da ECA. O compmus nesta época era composto pelo André Jucovsky Bianchi, Leandro Ferrari Thomaz, Santiago Davila, Danilo J. S. Bellini, Anderson Fraiha Machado, Andre Salim Pires, Arthur Tofani, Marcio Tomiyoshi e Santiago Davila. Nosso grupo foi parar na Torre da Princesa, um laboratório na Poli cedido pelo professor Régis Rossi Alves Faria que batizamos com este nome. O Drebs, sempre presente, comprou uma cafeteira e a Torre da Princesa passou a ser uma segunda casa.

O Julian se mudou e em casa chegou o Danilo Leite. Com o Danilo chegou a Dri. A casa voltou a ficar cheia e isto é sempre bom. Até festa junina em casa a gente fez.

Além dos colegas e amigos do compmus, teve o pessoal do Móbile, grupo de pesquisa com o pessoal da ECA. Coordenado pelos professores Fernando Iazzetta, Fábio Kon e Marcelo Queiroz, este grupo acabou por me abrir as portas da ECA e me permitiu conhecer muita gente boa. Alê Fenerich, Victor Kisil, Lilian Campesato, Alexandre Porres, Henrique Iwao, Mario Del Nunzio, Marcelo Muniz, Magno Caliman, André Bandeira, Boris Duque, Missionário José, Alexandre Marino e eu hei de esquecer alguém. Estudei com alguns, tomei café com outros, fiz planos com alguns e Sampa ficou menor.

Enquanto isto, no IME também aconteceu muita coisa legal. Claro, eu vim para estudar e aprendi muito. Aprendi com os professores e também com outros colegas. O Beraldo Leal que 
entende tudo de rede, Linux e C. O casal Ogro (Fernando) e Liz, o Vinícius, o Nelson Lago.

Alguns dos colegas do compmus terminaram seus estudos mas logo chegou mais gente. Antonio Deusany de Carvalho Junior, Antonio Goulart, Thilo Koch, Gilmar Dias, Roberto Piassi Passos Bodo, Guilherme Feulo do Espírito Santo, Pedro Henrique Rocha Bruel. Se bem que alguns destes chegaram apenas mais pro fim desta história. Bem, não sei se isto importa. Com este povo todo há uma certeza de boa companhia para um café servido pela Dona Jovita, Lúcia e Sandra na copa do IME.

No meio disto tudo, em algum lugar nesta história o Giu foi pra Alemanha e eu fui morar com o André Bordinhon. Engraçado a capacidade de ir morar com músicos. Com o Bordi eu morei pouco tempo pois logo após a mudança eu fui morar no Canadá graças a um convite do professor Marcelo Wanderley.

Para desespero dos meus pais, meu doutorado me levou ainda mais longe. Fui morar no Canadá. Em Montreal, fui acolhido pelo laboratório do Marcelo Wanderley (IDMIL), pelo MusicTech da McGill e pelo centro de pesquisa CIRMMT. Por lá encontrei muita gente bacana. Marcello Giordano, Marlon Schumacher, Mark Zadel, Stephen Sinclair, Joseph Malloch, Alfonso Perez Carrillo, Pieter-Jan Maes, Bertrand Scherrer, Mathab Ghamsari-Esfahani, Julian Vogels, Mailis Rodrigues, R. Michael Winters, Hakon Knutzen e tantos outros. Teve gente bacana de outros laboratórios também. Sven-Amin, Vincent, Harry.

Deixei separado os brasileiros do laboratório. Estes que me ajudaram a não sentir tanta saudades do Brasil e a não esquecer meu português: Carolina B. Medeiros, Fernando Falci de Souza, Pedro Henrique de Faria, Clayton Mamedes, Euler Teixeira. Nesta lista também entra meu orientador "Canadense", que na verdade é brasileiro, Marcelo Wanderley.

Acolhido academicamente pelo IDMIL, fui morar com um cara fantástico, Wissam Saliba, com quem fiz muitas jams e aprendi muito sobre o oriente médio. Por meio do Falci eu conheci um dos grandes amigos que fiz por lá, Siddhartha Shankar Rana. Adotei o Marcello Giordano como primo e agora que somos parentes podemos brigar. Pude visitar um colega de Linux Audio Conference, o russo-canadense Egor Sanin.

Na minha volta muita coisa tinha acontecido. Abandonamos a Torre, ganhamos um laboratório e nos mudamos para o CCSL. Quero dizer, o compmus mudou para o CCSL, e eu mudei com a Cassi para a lage da Zilah Marcelino, canto compartilhado com o Gustavo e o Dorival.

De tempos em tempos, uma visita à Maringá, um rock com o Marcos Silveira, Lucas Trabuco e André Chacal. Boas conversas com o Maestro Rael, Flávio Apro e Marcus Bittencourt.

E esta foi minha história. Foi assim ou quase assim. Nesta seção eu deveria agradecer a todos os aqui citados e mesmo tendo certeza de que já o fiz pessoalmente, farei novamente. Obrigado a todos vocês que permitiram que este doutorado acontecesse. Vocês fazem parte da minha história. Sem vocês nada disto seria possível. 


\section{Resumo}

SCHIAVONI, F. L. Medusa: Um ambiente musical distribuído. 2013. 119p. Tese (Doutorado) - Instituto de Matemática e Estatística, Universidade de São Paulo, São Paulo, 2013.

A popularização das redes de computadores, o aumento da capacidade computacional e sua utilização para produção musical despertam o interesse na utilização de computadores para comunicação síncrona de conteúdo musical. Esta comunicação pode permitir um novo nível de interatividade entre máquinas e pessoas nos processos de produção musical, incluindo a distribuição de atividades, pessoas e recursos em um ambiente computacional em rede. Neste contexto, este trabalho apresenta uma solução para comunicação síncrona de fluxos de áudio e MIDI em redes de computadores.

Além de permitir a comunicação, a solução proposta simplifica a conexão de recursos musicais e permite a integração de sistemas heterogêneos, como diferentes sistemas operacionais, arquiteturas de áudio e formatos de codificação, de forma transparente em um ambiente distribuído.

Como meio para alcançar esta solução, mapeamos requisitos e características desejáveis para este domínio de aplicação, a partir da interação com músicos e da análise de ferramentas relacionadas. Com base nestes requisitos e características projetamos uma arquitetura de sistema para o domínio específico de comunicação síncrona de conteúdo musical. Utilizando esta arquitetura como referência, implementamos uma biblioteca que compreende as funcionalidades essenciais para este domínio específico.

A fim de integrar esta biblioteca com diferentes bibliotecas de áudio e MIDI, desenvolvemos um conjunto de ferramentas que correspondem aos requisitos propostos e que permite aos usuários a utilização de conexões de rede em diversas ferramentas musicais.

Palavras-chave: Música em rede, Áudio, MIDI, Ambiente musical em rede, Performance musical em rede, comunicação musical síncrona. 


\section{Abstract}

SCHIAVONI, F. L. Medusa: A distributed music environment. 2013. 119p. Thesis (PhD) Instituto de Matemática e Estatística, Universidade de São Paulo, São Paulo, 2013.

The popularization of computer networks, the growth in computational resources and their use in music production have raised the interest in using computers for synchronous communication of music content. This communication may allow a new level of interactivity between machines and people in music production processes, including the distribution of activities, resources and people within a networked music environment. In this context, this work presents a solution for synchronous communication of audio and MIDI streams in computer networks.

Besides allowing communication, the proposed solution simplifies connections of music resources and allows the integration of heterogeneous systems, such as different operating systems, audio architecture and codification formats, transparently in a distributed environment.

As a means for accomplishing this solution, we mapped requirements and desirable features for this application domain, from the interaction with musicians and the analysis of related software. Based on these requirements and features, we designed a system architecture for the specific domain of synchronous communication of music content. Using this architecture as reference, we implemented a library that comprises the essential functionalities for this specific domain.

In order to integrate this library with different Audio and MIDI libraries, we developed a tool set that matches the proposed requirements and allows users to use network connections in several music tools.

Keywords: Network Music, Audio, MIDI, Network Music Environment, Network Music Performance, Synchronous music communication. 


\section{Sumário}

$\begin{array}{ll}\text { Lista de Figuras } & \text { ix }\end{array}$

Lista de Códigos $\quad$ xiii

Lista de Tabelas $\quad$ xv

Lista de Siglas $\quad$ xviii

1 Introdução $\quad 1$

1.1 Motivação e Cenários de Aplicação . . . . . . . . . . . . . . . . . . . . . . . . . 2

1.2 Trabalhos Relacionados . . . . . . . . . . . . . . . . . . . . . 4

1.3 Objetivos e Estrutura do Trabalho . . . . . . . . . . . . . . . 11

2 Fundamentação teórica e metodologia $\quad 13$

2.1 Desenvolvimento de Aplicações Musicais . . . . . . . . . . . . . . . . . . . . . . . 13

2.1 .1 Representação de Áudio . . . . . . . . . . . . . . . . . . . . . . . . . . . . . . . . . . . . . . . . . . . . 15

2.1 .2 Protocolo MIDI . . . . . . . . . . . . . . . . . . . . 15

2.1.3 APIs para o Desenvolvimento de Aplicações Musicais . . . . . . . . . . . . 16

2.2 Desenvolvimento de Aplicações em Rede . . . . . . . . . . . . . . . . . . . . . 18

2.2.1 Pilha de Protocolos TCP/IP . . . . . . . . . . . . . . . . 19

2.2 .2 Modos de Endereçamento . . . . . . . . . . . . . . . . . 25

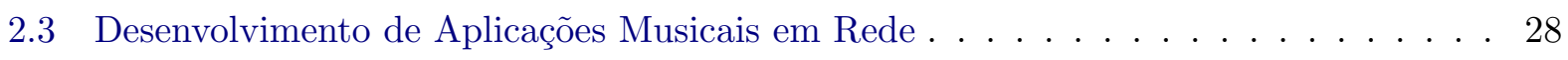

2.3 .1 Latência . . . . . . . . . . . . . . . . . . . . . . . . . . . 29

$2.3 .2 \quad$ Jitter . . . . . . . . . . . . . . . . . . . . 31

2.3 .3 Perda de Pacotes . . . . . . . . . . . . . . . . . . . . . . 31

2.4 Metodologia . . . . . . . . . . . . . . . . . . . . 32

2.4 .1 Levantamento de Requisitos . . . . . . . . . . . . . . . . . . . . . . 33

2.4 .2 Prototipação . . . . . . . . . . . . . . . . . . . 35

$\begin{array}{lll}3 & \text { Arquitetura proposta } & 37\end{array}$

3.1 Camada de Rede . . . . . . . . . . . . . . . . . . . . . . . . . . 38

3.2 Camada de Controle . . . . . . . . . . . . . . . . . . . 40

3.3 Camada de Aplicação . . . . . . . . . . . . . . . . . . . . . . . . . 45

3.4 Considerações . . . . . . . . . . . . . . . . . . . . . . 47 
4 Implementação $\quad 49$

4.1 Libmedusa . . . . . . . . . . . . . . . . . . . . . . . . 49

4.1 .1 Componentes de Apoio . . . . . . . . . . . . . . . . . . . . 49

4.1 .2 Camada de Rede . . . . . . . . . . . . . . . . . . . . . . 51 51

4.1 .3 Camada de Controle . . . . . . . . . . . . . . . . . . . . . . . 54

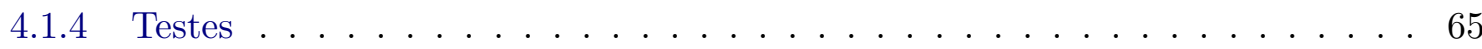

4.2 Camada de Aplicação . . . . . . . . . . . . . . . . . . . 66

4.2 .1 Interface de Usuário . . . . . . . . . . . . . . . . . . . 66

4.2 .2 Conectores de Som . . . . . . . . . . . . . . . . . . . 67

4.2 .3 Protótipos Desenvolvidos . . . . . . . . . . . . . . . . 69

5 Avaliação e Resultados $\quad \mathbf{7 3}$

5.1 Avaliação de Protocolos de Transporte . . . . . . . . . . . . . . . . . . . . . 73

5.1 .1 Ambiente de Medição . . . . . . . . . . . . . . . . . . . . . . . . 73

5.1 .2 Testes de Desempenho . . . . . . . . . . . . . . . . . . . . . . . 74

5.1 .3 Análise Preliminar dos Dados . . . . . . . . . . . . . . . 76

5.1 .4 Discussão . . . . . . . . . . . . . . . . . . . . . . 77

5.2 Avaliação dos Conectores MIDI . . . . . . . . . . . . . . . . . 78

5.2 .1 Comparação Teórica Entre APIs MIDI . . . . . . . . . . . . . . . . . . 78

5.2 .2 Ambiente de Medição . . . . . . . . . . . . . . . . . . . . . . . . . . . 79

5.2 .3 Testes de Desempenho . . . . . . . . . . . . . . . . . . . . 80

5.2 .4 Análise dos Dados . . . . . . . . . . . . . . . . . . . . 81

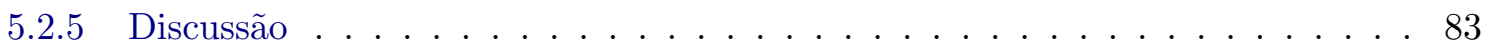

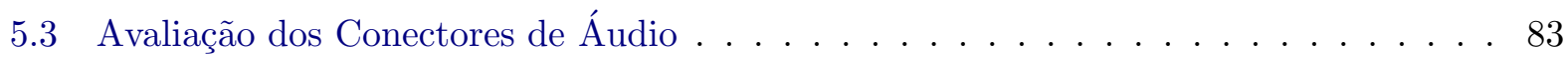

5.3 .1 Discussão . . . . . . . . . . . . . . . . . . . . 86

6 Conclusão $\quad 89$

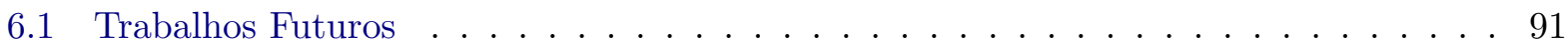

$\begin{array}{ll}\text { Referências Bibliográficas } & 93\end{array}$ 


\section{Lista de Figuras}

1.1 Arquitetura Básica de um Sistema de Transmissão de Áudio para Rede . . . . . . . 3

1.2 Interface Texto da Ferramenta Jacktrip . . . . . . . . . . . . . . . . 6

1.3 Interface Gráfica da Ferramenta Qjackctl Mostrando a Configuração do Jack Utilizando o NetJack como Driver de Som _ . . . . . . . . . . . . . . . . . 7

1.4 Interface Gráfica da Ferramenta Ninjam . . . . . . . . . . . . . . . . . 7

1.5 Interface Texto da Ferramenta Jack.udp . . . . . . . . . . . . . . . . . . 8

1.6 Interface Gráfica da Ferramenta llcon . . . . . . . . . . . . . . . . . . . 8

1.7 Interface Gráfica do Pure Data com os Objetos streamin e streamout . . . . . . . 9

1.8 Interface Gráfica de Configuração do Qmidinet . . . . . . . . . . . . . . . . . 9

1.9 Interface Gráfica do Soundjack . . . . . . . . . . . . . . . . . . . . 10

2.1 Exemplo de Buffer de Áudio Entrelaçado . . . . . . . . . . . . . . . . . . . . . 14

2.2 Exemplo de Buffer de Áudio não Entrelaçado . . . . . . . . . . . . . . . . . . . . . 14

2.3 Exemplo de Representação de Memória (Big Endian / Little Endian) . . . . . . . . . 14

2.4 Camadas de API de Áudio . . . . . . . . . . . . . . . . . . . . . . . . 17

2.5 Camadas da Pilha de Protocolos TCP/IP Baseada em Figura de [KR00] . . . . . . . 19

2.6 Formato de um Datagrama IP Baseada em Figura de $[$ Ste94 $]$. . . . . . . . . . . . . 19

2.7 Formato de um Datagrama UDP Baseada em Figura de [Ste94] . . . . . . . . . . . . 20

2.8 Formato do Segmento TCP Baseada em Figura de [Ste94] . . . . . . . . . . . . . . 21

2.9 Formato do Chunk SCTP Baseada em Figura de [HP08] . . . . . . . . . . . . . . 22

2.10 Formato do Datagrama DCCP Baseada em Figura de $[$ KHF03] . . . . . . . . . . . 23

2.11 Modos de Endereçamento de Rede . . . . . . . . . . . . . . . . . . . 25

2.12 Latência de Música em Rede . . . . . . . . . . . . . . . . . . . . . . . . . 30

2.13 Metodologia do Trabalho . . . . . . . . . . . . . . . . . . . . . 32

2.14 Primeiro Protótipo da Medusa . . . . . . . . . . . . . . . . . . . 35

2.15 Segundo Protótipo da Medusa . . . . . . . . . . . . . . . . 36

3.1 Visão da Arquitetura da Ferramenta. . . . . . . . . . . . . . . . . . . . 37

3.2 Diagrama de Componentes da Camada de Rede . . . . . . . . . . . . . . . . . . 38

3.3 Diagrama de Caso de Uso do Servidor Medusa . . . . . . . . . . . . . . . . 39

3.4 Diagrama de Caso de Uso do Cliente Medusa . . . . . . . . . . . . . . . . . . . . . 39

3.5 Relação entre os Componentes da Camada de Rede . . . . . . . . . . . . . . . . . . . 40

3.6 Diagrama de Componentes da Camada de Controle . . . . . . . . . . . . . . . . . . 41

3.7 Comunicação entre Remetente e Destinatário . . . . . . . . . . . . . . . . . . . . 41

3.8 Comunicação entre Controles Medusa . . . . . . . . . . . . . . . . . . . . 41 
3.9 Diagrama de Caso de Uso do Remetente Medusa . . . . . . . . . . . . . . . . . . . 41

3.10 Diagrama de Caso de Uso do Destinatário Medusa . . . . . . . . . . . . . . . . 42

3.11 Fluxo de Dados na Camada de Controle . . . . . . . . . . . . . . . . . . . . . 43

3.12 Diagrama de Caso de Uso do Controle Medusa . . . . . . . . . . . . . . . . . . . 44

3.13 Relação entre os Componentes da Camada de Controle . . . . . . . . . . . . . . . . . 45

3.14 Diagrama de Componentes da Camada de Aplicação . . . . . . . . . . . . . . . . . 46

3.15 Diagrama de Caso de Uso do Conector de Som . . . . . . . . . . . . . . . . 46

3.16 Diagrama de Caso de Uso do Medusa UI . . . . . . . . . . . . . . . . . . . 47

4.1 Separação entre a Libmedusa e as Implementações de Ferramentas . . . . . . . . . . 49

4.2 Lista Encadeada da Medusa . . . . . . . . . . . . . . . . . . . . . . . 50

4.3 Marcação de Tempo na Medusa . . . . . . . . . . . . . . . . . . . 50

4.4 Buffer Circular da Medusa . . . . . . . . . . . . . . . . . . . . . . . 50

4.5 Visão da Implementação da Camada de Rede . . . . . . . . . . . . . . . . . . . . 51

4.6 Configuração de Rede da Medusa . . . . . . . . . . . . . . . . . . . . . 52

4.7 Estrutura do medusa_server . . . . . . . . . . . . . . . . . . . 5 52

4.8 Diagrama de Atividades - Criar servidor . . . . . . . . . . . . . . . 54

4.9 Estrutura do medusa_client . . . . . . . . . . . . . . . . . . 5 54

4.10 Visão da Implementação da Camada de Controle . . . . . . . . . . . . . . . . . . . . 55

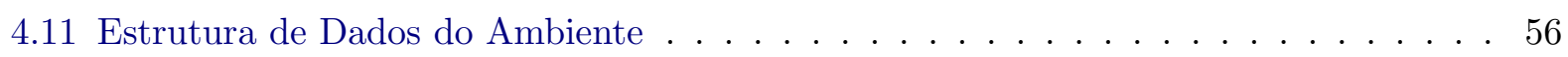

4.12 Estrutura de Dados do Medusa_control . . . . . . . . . . . . . . . . . . . . . 58

4.13 Estrutura de Dados de Recursos no Ambiente . . . . . . . . . . . . . . . . . . 59

4.14 Sequência de Processamentos para o Fluxo de Áudio . . . . . . . . . . . . . . . . . 59

4.15 Estrutura de Dados do medusa_sender . . . . . . . . . . . . . . . . 61

4.16 Estrutura de Dados do Medusa receiver . . . . . . . . . . . . . . . . 62

4.17 Diagrama de Atividades - Enviar / Receber Mensagens . . . . . . . . . . . . . . . 64

4.18 Mensagens Utilizadas pela Camada de Rede . . . . . . . . . . . . . . . . . . 64

4.19 Mensagens Utilizadas pelo medusa_control para Adicionar ou Remover um Nó do

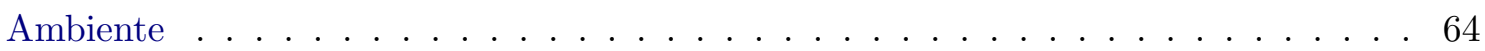

4.20 Mensagens Utilizadas pelo Medusa_control para Informar Recursos no Ambiente . 65

4.21 Mensagens Utilizadas pelo medusa_sender e medusa_receiver para Envio de Dados, Medições de Rede e Configuração de Áudio . . . . . . . . . . . . . . . . . . . . . . 65

4.22 Mensagens Utilizadas por Aplicações . . . . . . . . . . . . . . . . . . . . . 66

4.23 Representação das Entidades do Ambiente . . . . . . . . . . . . . . . . . . . . . . . . . . . 67

4.24 Ferramentas para Chat . . . . . . . . . . . . . . . . . . . 67

4.25 Adição de Sender ao Ambiente . . . . . . . . . . . . . . . . . . . . . . . . . . . . 67

4.26 APIs Utilizadas para a Implementações da Medusa . . . . . . . . . . . . . . . . . . . 68

4.27 Diagrama de Atividades - Criar Aplicação . . . . . . . . . . . . . . . . . 69

4.28 Implementação da Medusa em GTK . . . . . . . . . . . . . . . . . . . . 71

4.29 Integração da Medusa com o Pure Data e com o Ardour . . . . . . . . . . . . . . 71

4.30 Possibilidades de Conexão . . . . . . . . . . . . . . . . . . . . . . . 72

4.31 Ferramentas de $\log$ com Interface Texto e Gráfica . . . . . . . . . . . . . . . . 72

5.1 Resumo das Medições de Latência - 2 Canais. . . . . . . . . . . . . . . . . . . 77 
5.2 Resumo das Medições de Perda de Pacotes - 2 Canais. . . . . . . . . . . . . . . . 77

5.3 Latência de Entrada MIDI (Tempo 1) . . . . . . . . . . . . . . . . . . . . . . . . . . . . 82

5.4 Latência da Saída MIDI . . . . . . . . . . . . . . . . . . . . . 83

5.5 Implementação da Medusa em LADSPA. . . . . . . . . . . . . . . . . 84 


\section{Lista de Códigos}

1.1 Envio de Áudio por Rede: Solução Simples . . . . . . . . . . . . . . . . . . . . 2

1.2 Recebimento de Áudio por Rede: Solução Simples . . . . . . . . . . . . . . . . . . . . 2

4.1 Definição de Funções na Criação de um medusa_server . . . . . . . . . . . . . . . . 53

4.2 Utilização das Funções Definidas na Criação do medusa_server . . . . . . . . . . . . 53

4.3 Scripts de Testes com o Valgrind . . . . . . . . . . . . . . . . . . . . . . . . . . . . . . . . 66

4.4 Help da Ferramenta Medusa . . . . . . . . . . . . . . . . . . . . . . 69 


\section{Lista de Tabelas}

1.1 Resumo Tabular das Ferramentas Relacionadas . . . . . . . . . . . . . . . . . . . . 11

2.1 Tabela Comparativa de Protocolos de Transporte . . . . . . . . . . . . . . . . . . . 24

2.2 Relação entre Largura de Banda e Capacidade de Transmissão . . . . . . . . . . . . 29

3.1 Mensagens da Camada de Rede . . . . . . . . . . . . . . . . . . . . 39

3.2 Mensagens entre Remetente e Destinatário . . . . . . . . . . . . . . . . . . . . 43

3.3 Mensagens do Controle . . . . . . . . . . . . . . . . . . . . . . . . 45

3.4 Possibilidades de Mensagens da Camada de Aplicação . . . . . . . . . . . . . . . . . 47

5.1 Tempos (em ms) para a Conexão Localhost . . . . . . . . . . . . . . . . . . . . 75

5.2 Tempos (em ms) para a Conexão Crossover . . . . . . . . . . . . . . . 75

5.3 Tempos (em ms) para a Conexão Switch . . . . . . . . . . . . . . . . . . . 75

5.4 Tempos (em ms) e Perda de Pacotes para a Conexão Wireless Direta . . . . . . . . . 76

5.5 Tempos (em ms) e Perda de Pacotes para a Conexão Wireless com Access Point . . 76

5.6 Comparação Teórica das APIs MIDI . . . . . . . . . . . . . . . . 80

5.7 Medição de Latência (Tempos em ms) . . . . . . . . . . . . . . . . . . . . 81

5.8 Medições de Jitter (Tempos em ms) _ . . . . . . . . . . . . . . . . . . . . 81

5.9 Tempos de Note-off e Jitter (Tempos em ms) . . . . . . . . . . . . . . . . . . . . . 81

5.10 Comparação Teórica dos Conectores de Áudio . . . . . . . . . . . . . . . . . 86 


\section{Lista de Siglas}

\begin{tabular}{|c|c|}
\hline $\mathrm{AAC}$ & Advanced Audio Coding \\
\hline $\mathrm{ACK}$ & Acknowledgment \\
\hline $\mathrm{ADC}$ & Analog-to-digital Converter \\
\hline ALSA & Advanced Linux Sound Architecture \\
\hline API & Application programming interface \\
\hline ASIO & Audio Stream Input/Output \\
\hline CELT & Constrained Energy Lapped Transform \\
\hline DCCP & Datagram Congestion Control Protocol \\
\hline DSSI & Disposable Soft Synth Interface \\
\hline FFADO & Free FireWire Audio Drivers \\
\hline FFT & Fast Fourier Transform \\
\hline FLOSS & Free/Libre/Open Source Software \\
\hline GUI & Graphical user interface \\
\hline IP & Internal Protocol \\
\hline JACK & JACK Audio Connection Kit \\
\hline JUCE & Jules' Utility Class Extensions \\
\hline LADSPA & Linux Audio Developer's Simple Plugin API \\
\hline LAN & Local area network \\
\hline LV2 & LADSPA Version 2 \\
\hline MIDI & Musical Instrument Digital Interface \\
\hline MSS & Maximum Segment Size \\
\hline MTU & Maximum Transmission Unit \\
\hline NAT & Network Address Translation \\
\hline
\end{tabular}


OSS Open Sound System

PCM Pulse Code Modulation

PD Pure Data

RDF Resource Description Framework

RTCP Real-time Transport Control Protocol

RTP Real-time Transport Protocol

RTSP Real-time Streaming Protocol

SCTP Stream Control Transmission Protocol

SDK Software Development Kit

SDL Simple DirectMedia Layer

TCP Transmission Control Protocol

TTL Time to live

TUI Text-based user interface

UDP User Datagram Protocol

UI User Interface

ULD Ultra Low Delay

UML Unified Modeling Language

VST Virtual Studio Technology

WAN Wide area network 


\section{Capítulo 1}

\section{Introdução}

A capacidade de reproduzir músicas associada aos formatos de arquivos digitais e a possibilidade de cópias sem perda de qualidade, além da distribuição de áudio via Internet, fizeram com que os computadores se tornassem o aparelho de som e a discoteca de muitos lares e pessoas. Saindo do âmbito da música como entretenimento, a computação vem também conquistando músicos e artistas. No meio artístico musical é crescente a utilização do computador como uma ferramenta de apoio [Iaz10]. Há diversas ferramentas computacionais para apoiar o processo musical em suas várias etapas abrangendo a composição, gravação, masterização, performance e a distribuição de material musical. Exemplos destas ferramentas são aplicações para notação de partituras, gravação, simulação de instrumentos e a utilização das redes de computadores para a distribuição de conteúdo musical ${ }^{1}$.

A distribuição de conteúdo musical por meio de redes de computadores muitas vezes é feita apenas de maneira assíncrona. Isto significa que a transmissão pode ser feita a qualquer momento e não apenas no momento em que a música está sendo executada, e que o tempo de transmissão pode ser maior ou menor que a duração desta música. Tal utilização, apesar de ser de grande valia, não prevê a interação entre músicos e ferramentas durante o processo de criação, gravação ou performance musical. Para performances envolvendo redes de computadores, por exemplo, é necessária uma comunicação síncrona, em que o conteúdo musical é transmitido ao mesmo tempo em que é criado.

Ferramentas como o Skype, Google Talk ou MSN permitem a comunicação síncrona de áudio, porém estas ferramentas estão focadas na transmissão de voz. Por este foco, a preocupação destas ferramentas está em representar as frequências onde a voz humana atua; além disto, a preocupação com a integridade do conteúdo transmitido refere-se principalmente à inteligibilidade. Este tipo de codificação do sinal de áudio, que é satisfatório para a comunicação verbal, é insuficiente para aplicações musicais profissionais. Existem outras ferramentas que satisfazem os requisitos de transmissão de áudio com qualidade e em tempo real: Jacktrip [Cha11], NetJack [LAM09], Ninjam, Jack.udp, llcon, streamin $\sim$ / streamout e SoundJack [CRV06, CKS06]. Tais ferramentas resolvem uma parte do problema da transmissão de áudio em rede, mas introduzem novos problemas, tais como a dificuldade de configuração da rede e de aplicativos relacionados à transmissão, bem como a falta de ferramentas de diagnóstico e monitoramento das conexões criadas[ATIQ13]. Estas ferramentas são apresentadas na Seção 1.2 (página 4) deste texto.

Este trabalho traz a especificação de uma biblioteca que possibilite a integração de pessoas, ferramentas e conteúdos musicais em computadores e plataformas distintos, interligados por uma rede de computadores. Baseado nesta biblioteca, este trabalho traz ainda a implementação de algumas ferramentas que, além de permitir tal integração, devem simplificar a criação e gerenciamento de conexões de rede e também solucionar automaticamente possíveis problemas relacionados ao uso simultâneo de diferentes codificações de áudio ou de rede. Tal biblioteca pode ser utilizada para criar um ambiente musical distribuído, trazendo para cada participante do processo informações

\footnotetext{
${ }^{1}$ Utilizamos o termo conteúdo musical aqui para referenciar duas representações digitais de música em computador: áudio e MIDI
} 
em tempo real do que acontece em todo o ambiente.

A presente pesquisa foi feita junto ao Grupo de Pesquisas em Computação Musical da Universidade de São Paulo, associado ao projeto Temático MOBILE/FAPESP (processo 2008/08632-8). Este projeto temático reuniu pesquisadores de várias áreas, como músicos, engenheiros eletricistas, físicos e cientistas da computação, em torno do tema interação e música.

\subsection{Motivação e Cenários de Aplicação}

O envio de conteúdo musical por redes de computadores é constituído basicamente por uma arquitetura de áudio que permita capturar saídas de som para enviá-las por meio de um protocolo de rede. O recebimento deste conteúdo por outro nó depende de um cliente para receber os pacotes da rede, que é responsável por entregar localmente estes pacotes para um servidor de áudio ou outra aplicação. Isto poderia ser realizado sem a construção de ferramentas adicionais; por exemplo, em Linux podemos utilizar a seguinte sequência de comandos apresentados no Código1.1 e 1.2 para enviar e receber conteúdo musical pela rede:

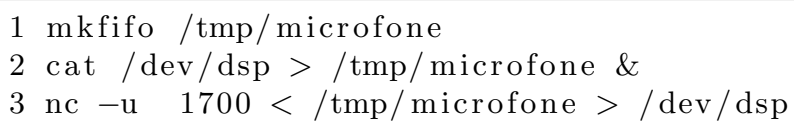

Código 1.1: Envio de Áudio por Rede: Solução Simples

$1 \mathrm{mkfifo} / \mathrm{tmp} /$ inputvoice

2 nc ip_do_servidor - u $1700</$ tmp/inputvoice $>/$ dev/dsp

Código 1.2: Recebimento de Áudio por Rede: Solução Simples

É possível que tal sequência de comandos pudesse atender satisfatoriamente a alguns cenários (e usuários) específicos. No entanto, apresentamos tal sequência para ilustrar algumas dificuldades existentes na implementação de uma ferramenta genérica. Algumas razões pelas quais este exemplo não pode ser considerado uma solução para o problema são:

- O exemplo possui um grau de complexidade que dificultaria muito o uso por parte de usuários leigos, exigindo o conhecimento de convenções do sistema operacional em relação aos dispositivos de áudio e de números de IP e porta das máquinas envolvidas.

- Esta solução possui pouca flexibilidade: ao tratar o fluxo de áudio como se fosse um texto que é enviado/recebido diretamente ao/do dispositivo de som, excluem-se todas as codificações de áudio que não são processadas nativamente pela interface de som.

- Não há informações quanto à codificação do áudio enviado pela rede: a menos que os pares combinem de antemão quais são os parâmetros e codecs utilizados, seria praticamente impossível decodificar o fluxo recebido.

- Esta solução restringe-se a enviar a entrada de microfone para a rede e receber dados nas saídas de som do computador não permitindo o envio de outra fonte sonora nem o recebimento de outro tipo de entrada.

- Esta solução não permite o envio simultâneo de vários canais de áudio: mesmo que o código fosse replicado para utilizar vários arquivos e portas diferentes, e os processos começassem simultaneamente, não haveria nenhuma garantia de sincronização dos fluxos enviados/recebidos correspondentes aos diversos canais.

- Dificilmente podemos integrar esta solução a uma ferramenta já existente, visto que apenas ferramentas que dependem do OSS (Open Sound System) utilizam diretamente o dispositivo / dev/dsp, e mesmo essas ferramentas não permitiriam normalmente o redirecionamento de suas entradas e saídas através de pipes UNIX. 
- Esta solução não é portável entre sistemas operacionais.

Cada uma destas razões aponta para um problema específico que deve ser resolvido por uma ferramenta de distribuição de áudio em rede. Entretanto, apesar destes problemas e limitações, esta solução simplista traz em si um modelo de como uma ferramenta, que atendesse ao mesmo propósito, poderia ser desenvolvida.

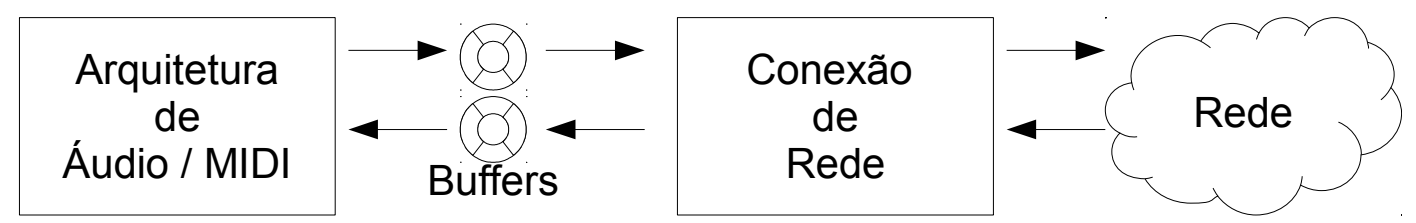

Figura 1.1: Arquitetura Básica de um Sistema de Transmissão de Áudio para Rede

A Figura 1.1 ilustra o fato de que um sistema de transmissão deve incluir alguns elementos como uma arquitetura de áudio / MIDI para captura e reprodução do conteúdo, um buffer para sincronizar o dispositivo de som com o dispositivo de rede e uma conexão de rede para enviar e receber os dados.

Uma análise mais detalhada pode nos levar a decisões específicas de projeto relativas a estes elementos, em particular a escolha de uma arquitetura de som que se adeque ao cenário de aplicação pretendido, de uma conexão de rede que seja também adequada a este cenário, e também de um mecanismo para sincronizar os dispositivos envolvidos.

Várias ferramentas relacionadas foram mapeadas neste trabalho e funcionam de maneira semelhante à da arquitetura básica aqui apresentada (Figura 1.1), estendendo-a de maneiras diferentes. Tais ferramentas resolvem o problema da comunicação de dados musicais para diversos cenários, porém características interessantes que encontram-se presentes em algumas delas não estão presentes em outras. Tais ferramentas serão apresentadas na Seção 1.2 deste documento.

A análise das ferramentas relacionadas e suas características, bem como a experiência compartilhada com músicos interessados neste tipo de comunicação e a observação de suas dificuldades e anseios, nos motivaram a construir outra ferramenta. Tal motivação encontra-se primeiramente na intenção de implementar as características consideradas importantes nos trabalhos anteriores em uma única ferramenta. Permitir o envio de áudio e MIDI seria um exemplo da união de características de ferramentas distintas em uma única ferramenta.

Uma segunda motivação é permitir que várias arquiteturas de áudio e MIDI possam ser utilizadas para a captura / reprodução de dados musicais. Incluir outras arquiteturas permitiria que músicos pudessem incorporar o mecanismo de transmissão em rede às ferramentas computacionais de suas preferências.

Outra motivação corresponde a ampliar as possibilidades de comunicação em rede e as possibilidades de conexões. Uma ferramenta flexível que trabalhe com vários protocolos de transporte, endereçamentos e tipos de conexões poderia expandir as possibilidades de utilização de redes de computadores no domínio musical, adaptando-se, através destas configurações, a cenários de aplicação distintos. Alguns exemplos destes cenários são:

Performance Distribuída O uso de dispositivos de áudio e dispositivos computacionais em apresentações musicais envolve uma grande quantidade de meios de conexão como mesas, patch bays e cabos de áudio. Isto poderia ser simplificado concentrando-se a distribuição do conteúdo musical em uma rede de computadores sem fio ou por cabo. Além de simplificar as conexões, a utilização de uma rede pode ampliar a capacidade de conexão além do que os dispositivos tradicionais permitiriam, como, por exemplo, permitindo o envio de mais canais de áudio do que a interface física (mesa de som) possui;

Sonorização A sonorização de apresentações musicais, teatrais ou cinematográficas envolve a espacialização do som em vários canais de áudio. Tal atividade requer 
equipamentos específicos que são dispendiosos e geralmente de difícil instalação. Esta dificuldade se dá tanto pela fragilidade do sinal de áudio convencional em relação à interferência eletromagnética quanto pela distância máxima que pode ser empregada para a conexão tradicional de cabos de áudio. A utilização de redes de computadores permite ao sinal de áudio trafegar por cabos de rede que possuem menos limitação de distância e sofrem menos interferência eletromagnética;

Gravação $\mathrm{O}$ trabalho de produção musical envolve várias pessoas em ambientes diferentes, tais como músicos, técnicos para a captação de som e técnicos de mixagem e masterização. A transmissão de conteúdo musical via rede permite, por um lado, a gravação remota, desobrigando técnicos de mixagem de estarem no mesmo local que os músicos e técnicos de captação; por outro lado, no caso de gravação presencial, o uso de rede Wi-Fi permitiria a total eliminação tanto dos cabos de áudio quanto de rede;

Processamento Distribuído de Sinais Algumas aplicações musicais podem exigir um alto desempenho computacional, seja pelo uso de técnicas dispendiosas de processamento de sinais ou pelo processamento simultâneo de muitos canais de áudio. A utilização de várias máquinas em rede pode garantir um aumento de desempenho escalonável, permitindo que novos recursos computacionais sejam adicionados quando necessário.

Cada um destes cenários possui diferentes níveis de exigência em relação à qualidade do sinal, e diferentes níveis de tolerância em relação à latência. Numa situação de concerto a tolerância a ruídos e a exigência de qualidade de sinal são mais baixas do que numa situação de gravação; em contrapartida, a tolerância à latência no concerto é muito mais baixa, sendo excepcionalmente alta no caso de uma gravação remota.

Para desenvolver uma ferramenta computacional que simplifique a utilização de redes de computadores para atividades musicais devemos não apenas contemplar todas estas possibilidades de configuração, como também mapear as reais expectativas dos possíveis usuários. Partindo do desenvolvimento desta ferramenta, novas performances, apresentações e mesmo novos processos de produção musical poderão surgir visando explorar esta tecnologia, potencialmente trazendo novos horizontes de pesquisa para as áreas da música e da computação musical.

\subsection{Trabalhos Relacionados}

As ferramentas relacionadas apresentadas nesta Seção trazem em si a arquitetura básica descrita anteriormente, e boa parte delas expande esta arquitetura básica de forma a eliminar algumas das limitações citadas na Seção 1.1. Com o intuito de comparar tais soluções, apresentaremos uma série de ferramentas de transmissão de sinais de áudio e controle em rede.

As ferramentas selecionadas para esta análise são: Jacktrip, Netjack, Ninjam, jack.udp, llcon e os externals ${ }^{2}$ do Pure Data streamin $\sim$ e streamout $\sim$. Esta lista representa uma seleção abrangente de ferramentas que estão publicadas sob licenças livres e permitem a transmissão de áudio em tempo real. Adicionamos a esta lista a ferramenta QmidiNet, que trabalha exclusivamente com MIDI, e o aplicativo SoundJack, que não possui código-fonte disponível, mas que conta com diversos artigos científicos sobre o seu desenvolvimento. Devido a diferente quantidade de informações disponíveis sobre cada ferramenta e também uma maior ou menor quantidade de características, a apresentação destas ferramentas tende a ser maior para as ferramentas mais complexas e com mais informações disponíveis e menor para as ferramentas mais simples ou com menos informações disponíveis. De qualquer forma, não é intenção deste trabalho valorizar mais uma ferramenta do que outras.

Tal lista não é de forma alguma exaustiva, pois há uma série de outras ferramentas para música em rede, algumas com código fechado e pouca informação disponível, outras com objetivos diferentes

\footnotetext{
${ }^{2}$ Objetos Pure Data escritos em C.
} 
dos considerados aqui. Apresentamos a seguir uma pequena lista de aplicativos que se relacionam com a distribuição de conteúdo musical em redes, mas que não se encaixam no critério de seleção adotado:

- O protocolo de comunicação OSC [Wri05] tem sido muito utilizado para a criação de novos instrumentos e distribuição de sinais de controle para aplicações musicais conectadas por rede [SFW10], sem contudo possuir como objetivo a distribuição de áudio ou MIDI [Wri05].

- O software OtherSide ${ }^{3}$ [Ana09] permite a síntese remota de sinais em um servidor web controlado por meio de mensagens OSC, enviadas através de uma interface CGI:IRC para navegadores web. Como no exemplo acima, apenas sinais de controle (e não de áudio) são transmitidos por rede.

- O software Quintet.net [Haj03] é uma ferramenta feita em MAX/MSP que permite utilizar som e vídeo distribuído pela Internet. Por ser dependente do ambiente fechado MAX/MSP, ela não pode ser estendida no contexto de FLOSS (Free/Libre/Open Source Software), pois suas dependências (neste caso, o próprio ambiente MAX/MSP) não podem ser distribuídas livremente junto com outras extensões.

- O LDAS (Low Delay Audio Streamer) [SS06] era uma ferramenta para Linux que usava o protocolo UDP para o transporte de áudio capturado via ALSA. Foi lançado em 2005 e apresentado na Linux Audio Conference de 2006, e possuía vários objetivos em comum com o presente trabalho. Lamentavelmente o código-fonte não está mais disponível, sendo que a página do projeto está atualmente fora do ar.

Além destas, há ainda outras ferramentas que se propõem a resolver o problema de transmissão de áudio em tempo real por rede, mas que não possuem código aberto ou documentação técnica para uma análise de seu funcionamento. Entre estas ferramentas, é possível citar o eJamming ${ }^{4}$ e o Rewire $^{5}$.

A seguir descreveremos com certo nível de detalhamento as ferramentas que se relacionam com o contexto deste trabalho.

\section{JackTrip}

O Jacktrip ${ }^{6}$ foi desenvolvido por Chris Chafe e por Juan-Pablo Cáceres no CCRMA da Universidade de Stanford, Califórnia, em 2008 [Cha11]. Esta ferramenta foi utilizada em diversas apresentações do grupo de pesquisa SoundWIRE (Sound Waves on the Internet from Real-time Echoes) e combina diversas técnicas computacionais para lidar com o problema de latência e perda de pacotes [CC09b]. O Jacktrip é integrado ao servidor de som JACK [CC09a].

Desenvolvido em C++ e utilizando a biblioteca Qt [CC09a], o Jacktrip possibilita a utilização de um sistema de redundância de pacotes para garantir a integridade no recebimento dos dados. Cada mensagem UDP possui um número sequencial e um buffer circular é utilizado para ordenar os pacotes recebidos. Como no protocolo UDP os segmentos de dados podem ser entregues mais de uma vez, o mecanismo de alimentação do buffer circular trata da triagem dos segmentos que ainda não foram recebidos e daqueles duplicados e que podem ser descartados. Além disso, o uso de um buffer permite amortizar as variações no atraso da rede (conhecidas como jitter), garantindo que a entrega dos dados mantenha uma taxa constante de atualização, às custas de um pequeno aumento na latência ${ }^{7}$.

\footnotetext{
${ }^{3}$ http://otherside.gnufunk.org/ Acessada em 01/12/2013.

${ }^{4}$ http://ejamming.com/ Acessada em 01/12/2013.

${ }^{5}$ http://www.propellerheads.se/products/reason/index.cfm Acessada em 01/12/2013.

${ }^{6}$ http://code.google.com/p/jacktrip/ Acessada em 01/12/2013.

${ }^{7} \mathrm{~A}$ transmissão de dados sem nenhum buffer é extremamente arriscada, pois neste caso todo pacote perdido se converteria em ruído
} 


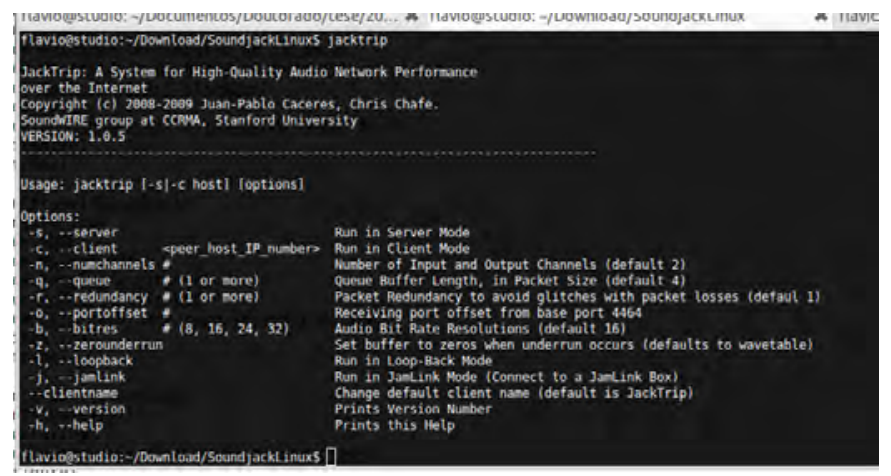

Figura 1.2: Interface Texto da Ferramenta Jacktrip

O Jacktrip utiliza como padrão uma taxa de amostragem do sinal de áudio igual a $44.100 \mathrm{~Hz}$ com amostras de 16 bits. Para realizar compactação (com perdas) e redução da largura de banda, necessárias para o tráfego de vários canais em rede, o codec CELT pode ser utilizado[Tom13].

O modelo conceitual de comunicação implementado no Jacktrip é uma arquitetura do tipo cliente-servidor, porém restrito a apenas um cliente por servidor, tornando-o na prática um sistema peer-to-peer. Quando o servidor é instanciado e o cliente se conecta, uma mesma quantidade de canais é criada para envio e recebimento de sinais.

\section{NetJack}

O NetJack ${ }^{8}$ foi desenvolvido por Torben Hohn, Dan Mills e Robert Jonsson. É atualmente a ferramenta de distribuição de sinais de áudio e controle que funciona integrada ao servidor de áudio JACK [LAM09]. A arquitetura desta ferramenta utiliza um modelo mestre/escravo no qual os nós mestres utilizam o backend de áudio do JACK e um cliente interno de rede para trocar conteúdo musical com os escravos, que utilizam o backend de rede do JACK [CHW09].

Neste modelo, para cada par de nós que queiram estabelecer uma conexão para trocar sinais de áudio, é necessário que um deles assuma o papel de mestre e o outro de escravo. Um nó que roda a aplicação como mestre pode se conectar a vários escravos, mas cada instância da aplicação configurada como nó escravo só se conecta a um único mestre. Os nós escravos são totalmente configurados (taxa de amostragem, tamanho de bloco, etc) pelo nó mestre.

O Netjack utiliza o protocolo UDP e adiciona uma identificação temporal aos pacotes para reordená-los no buffer circular do receptor. Esta identificação é utilizada para sincronizar as placas de som como um relógio mundial distribuído, onde as máquinas escravas devem converter sua taxa de amostragem (Sample Rate Conversion - SRC), para compensar o clock drift ${ }^{9}$ entre escravos diferentes.

O NetJack permite o uso do codec CELT para codificação de áudio. Além da transmissão de áudio, o NetJack também permite o envio de MIDI e o controle remoto da funcionalidade Transport do JACK, responsável pela sincronização de processos remotos (por exemplo, o início da reprodução em uma máquina concomitante com o início da gravação em outra máquina).

\section{Ninjam}

O Ninjam ${ }^{10}$ está sendo desenvolvido desde 2005 pela Cockos Incorporated em um projeto liderado por Justin Frankel, um dos criadores do programa de compartilhamento de arquivos Gnutella e do reprodutor de mídia Winamp. Ao contrário dos demais programas que tentam evitar latência,

\footnotetext{
${ }^{8}$ http://netjack.sourceforge.net/ Acessada em 01/12/2013.

${ }^{9}$ Duas interfaces de áudio podem apresentar desvios na medição do tempo devido ao fato de seus pulsos serem providos por cristais que vibram aproximadamente (mas não exatamente) na mesma frequência.

${ }^{10}$ http://www.ninjam.com Acessada em 01/12/2013.
} 


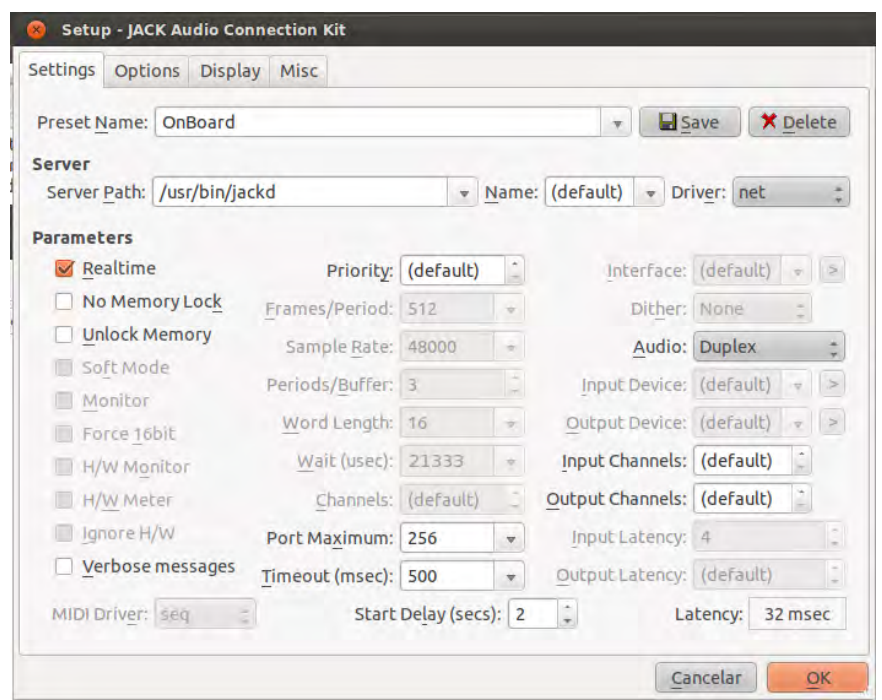

Figura 1.3: Interface Gráfica da Ferramenta Qjackctl Mostrando a Configuração do Jack Utilizando o NetJack como Driver de Som

o Ninjam adiciona propositalmente um compasso $^{11}$ de latência por meio de um buffer, de forma que os músicos sempre escutam o sinal um compasso atrás do que estão tocando - e portanto precisam tocar sempre um compasso à frente do que estão escutando. Com o uso de uma latência tão alta a ferramenta consegue evitar o jitter da rede, introduzindo no entanto um descompasso na relação natural entre escutar e reagir, exigindo dos participantes da performance algum tipo de adaptação na técnica e no repertório. Segundo os desenvolvedores, o Ninjam foi desenvolvido com ênfase em experimentações e expressões musicais onde este descompasso possa ser interpretado como parte da proposta estética e não como limitação técnica.

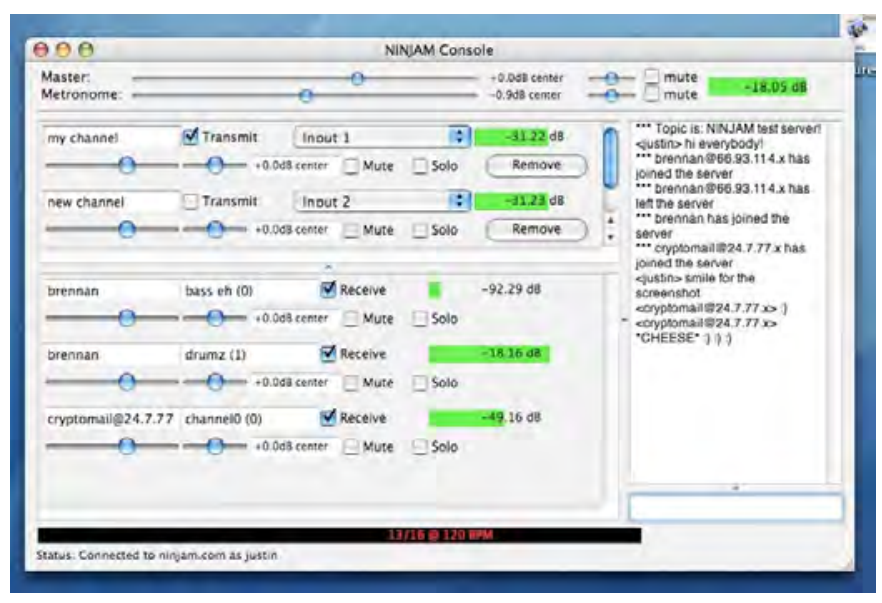

Figura 1.4: Interface Gráfica da Ferramenta Ninjam

O programa utiliza uma arquitetura cliente-servidor, na qual é necessário manter um servidor ativo para que os clientes possam se conectar. Para diminuir a largura de banda necessária para o tráfego de áudio na rede, o Ninjam utiliza o codec OGG Vorbis (de compressão com perdas). O tráfego de dados é feito por meio do protocolo TCP (https:/github.com/wahjam/wahjam/wiki/ Ninjam-Protocol), que garante ausência de perdas de pacotes através de um sistema de mensagens de confirmação de recebimento. Finalmente, o Ninjam possui distribuição para Windows (por meio da API de multimídia nativa), Linux (por meio do ALSA) e MacOSX (por meio do Core Audio).

\footnotetext{
${ }^{11}$ No Ninjam a configuração da latência do sistema usa a noção de compasso em um sistema métrico-musical, mas na prática essa configuração se refere a uma medida de tempo fixada previamente, que os músicos/usuários usarão como referência para a sincronização.
} 


\section{Jack.udp}

O Jack.udp ${ }^{12}$ foi desenvolvido por Rohan Drape em 2003 [SS06], e corresponde a um mecanismo de transporte UDP para o servidor de som JACK, sendo distribuído através de um pacote chamado "jack tools" nas distribuições Linux Debian e Ubuntu. Esta aplicação pode ser executada em dois modos: modo de envio e modo de recebimento. No modo de envio a aplicação lê pacotes de áudio de portas de entrada do JACK e envia pacotes UDP para uma determinada porta/IP na frequência dos ciclos DSP determinada pelo servidor JACK local. No modo de recebimento a aplicação lê pacotes recebidos pela rede na porta indicada e escreve os dados recebidos em um buffer associado a uma porta de saída do JACK. Além dos dados de conexão de rede como IP e porta, a ferramenta permite configurar o tamanho do buffer circular entre a rede e o JACK, sendo o padrão 4096 amostras.

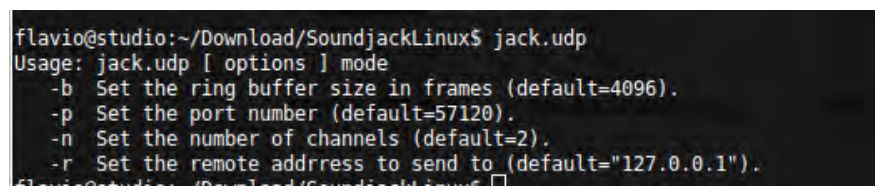

Figura 1.5: Interface Texto da Ferramenta Jack.udp

\section{llcon}

O llcon $^{13}$ (Low-Latency (internet) Connection tool), depois renomeado para Internet Jam Session software, está sendo desenvolvido por Volker Fischer desde 2004. Este software foi feito para utilizar conexões de redes com banda de transmissão bastante limitada, como por exemplo conexões ADSL com 256Kbps [Ana09], podendo ser utilizado para conectar vários usuários a um servidor central. A ferramenta trabalha com uma topologia em estrela, sendo sempre necessária a presença de um servidor central para garantir a conexão entre clientes. O servidor central irá mixar todos os sinais recebidos e devolverá aos clientes os sinais mixados. Caso um cliente queira enviar vários canais de áudio ou um canal estéreo, os canais serão mixados localmente de modo que apenas um canal de fato seja enviado ao servidor central.

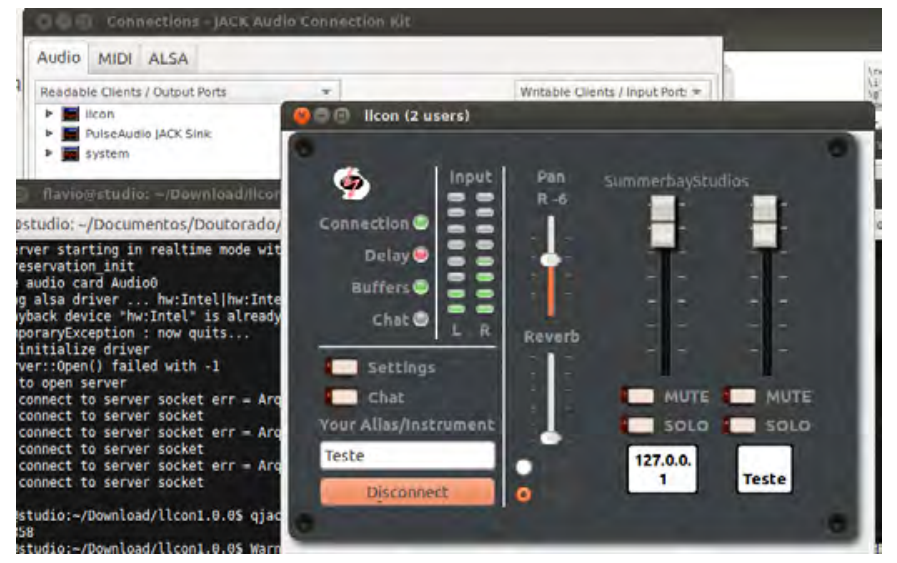

Figura 1.6: Interface Gráfica da Ferramenta llcon

O software trabalha com uma frequência de amostragem de $24 \mathrm{kHz}$ com o CODEC de áudio CELT (o codec anterior IMA-ADPCM foi abandonado a partir da versão 3 da ferramenta, pois acarretava um atraso maior por causa da codificação). Assim, independentemente da codificação utilizada nos clientes, os dados serão sempre codificados dessa maneira ao trafegar pela rede, e decodificados localmente para uso de outras aplicações.

\footnotetext{
${ }^{12}$ http://www.slavepianos.org/rd/sw/sw-23/ Acessada em 01/12/2013.

${ }^{13}$ https://sourceforge.net/apps/mediawiki/llcon/index.php Acessada em 01/12/2013.
} 
O llcon funciona em Windows por meio de um driver ASIO, em MacOSX com Core Audio e em Linux usando o servidor JACK.

\section{streamin $\sim /$ streamout $\sim$}

Desenvolvido em 1999 por Guenter Geiger, estes externals permitem enviar e receber fluxos (streams) de áudio dentro do Pure Data. Desenvolvidos para troca de áudio em redes locais, os mesmos não possuem nenhum tipo de compactação ou correções para perdas de pacotes ou para sincronização entre os pares. O único parâmetro configurável que permite diminuir a largura de banda necessária para o tráfego de dados é a resolução das amostras, que pode utilizar 8 bits, 16 bits ou 32 bits. Para resolver diferenças entre os pares, informações sobre o número de canais e resolução são enviadas juntamente com as amostras de áudio.

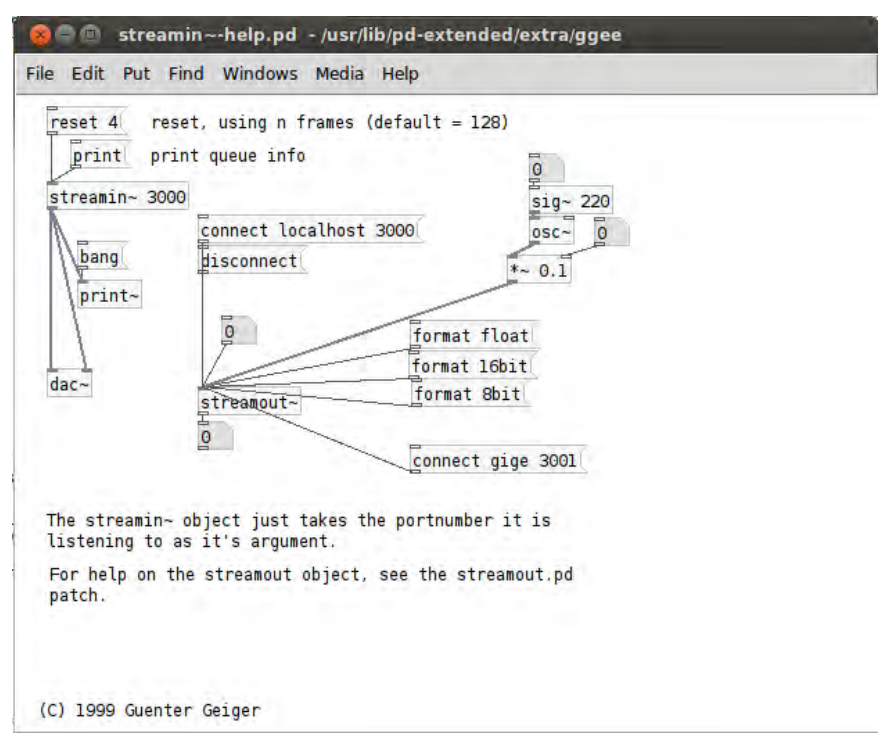

Figura 1.7: Interface Gráfica do Pure Data com os Objetos streamin e streamout

Distribuídos com a versão Extended do Pure Data, estes externals encontram-se disponíveis em versões do Pure Data para todos os sistemas operacionais.

\section{QMidinet}

O QMidinet ${ }^{14}$ foi desenvolvido por Rui Nuno Capela e é parte do conjunto de ferramentas $\mathrm{Q}^{15}$ para música em Linux, que inclui qjackctl, qtractor, qsynth, qsampler, entre outros.

Este aplicativo empacota mensagens MIDI em pacotes UDP e se conecta tanto com o JACK MIDI quanto com o ALSA MIDI, criando uma porta virtual nestas APIs. O envio é via UDP Multicast e foi desenvolvido utilizando o Qt. Sua configuração permite definir a quantidade de portas virtuais e a porta para o envio / recebimento. O número de portas utilizado será o mesmo tanto para o envio quanto para o recebimento.

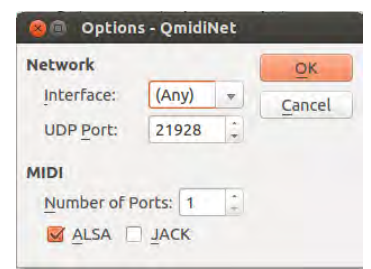

Figura 1.8: Interface Gráfica de Configuração do Qmidinet

\footnotetext{
${ }^{14}$ http://qmidinet.sourceforge.net/ Acessada em 01/12/2013.

${ }^{15}$ http://www.rncbc.org/drupal/node/13 Acessada em 01/12/2013.
} 


\section{SoundJack}

O SoundJack ${ }^{16}$ foi desenvolvido por Alexander Carôt no ISNM da Universidade de Lübeck/Alemanha e propõe transformar um computador em um servidor de streams UDP para trabalhar com performances em rede [CRV06, CKS06]. Apesar de não possuir código aberto, há vários artigos publicados e a tese de doutorado do autor que trazem informações sobre o funcionamento desta ferramenta.

O SoundJack funciona para os sistemas Windows, Linux e OSX e pode utilizar os codecs CELT ou ULD para diminuir a quantidade de dados transferidos [CW08]. Segundo o autor, estas opções foram incluídas pois a intenção desta ferramenta é funcionar sobre uma conexão ADSL comum. O desenvolvimento deste software foi feito utilizando a biblioteca Qt em $\mathrm{C}++$.

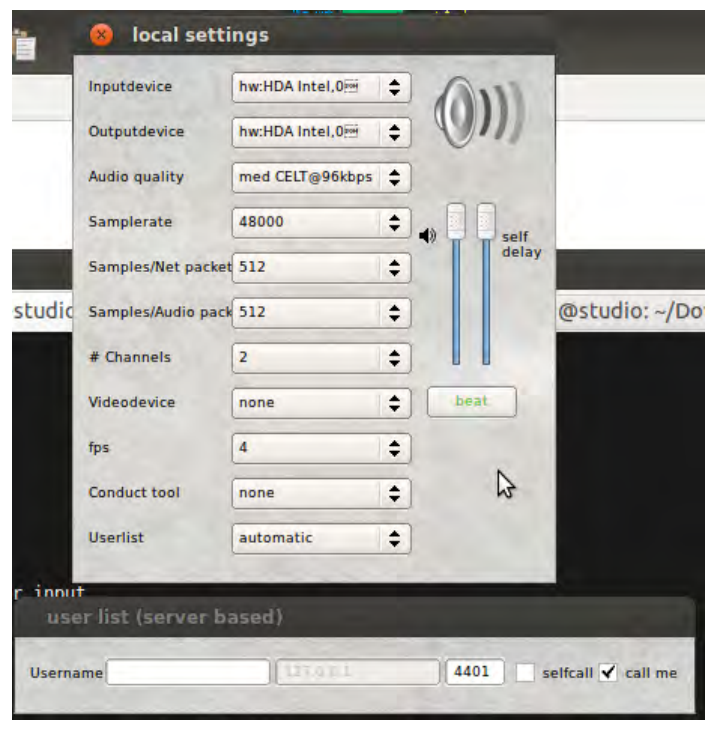

Figura 1.9: Interface Gráfica do Soundjack

Segundo a tese do autor, esta ferramenta utiliza um sistema de reamostragem para ajustar diferenças temporais entre máquinas diferentes (world-clock drift). Para isto, em todos os pacotes de áudio enviados é enviado também um timestamp; ao receber um pacote de áudio, a ferramenta verifica o instante local em que o mesmo foi enviado (em relação à taxa de amostragem e ao tamanho de bloco), calculando a diferença que o pacote tem em relação ao seu tempo lógico local, para então garantir a sincronização dos blocos [CW09].

O SoundJack também possui uma espécie de ping de áudio: um pacote ICMP que contém dados de áudio e que pode ser respondido por qualquer máquina que esteja habilitada a responder ao comando PING. Assim, é possível medir tempo de latência utilizando o protocolo ping tradicional, mas com dados reais de áudio, sem que nenhuma configuração adicional seja necessária em relação à máquina destino [CRW08].

\section{Resumo das Ferramentas Relacionadas}

Apesar das ferramentas relacionadas possuírem características distintas e serem feitas para atender metas diferentes, algumas características destas ferramentas são resumidas na Tabela1.1 abaixo para efeito de comparação.

Além deste resumo, podemos listar algumas características desejáveis para uma nova ferramenta de transmissão de áudio que foram percebidas no estudo das ferramentas relacionadas. Entre parênteses nos itens abaixo são listadas as ferramentas que implementam a funcionalidade do item:

- Utilizar CODECs para a compactação do fluxo de áudio a ser transmitido (Jacktrip, Netjack, Soundjack);

\footnotetext{
${ }^{16}$ http://www.soundjack.eu/ Acessada em 01/12/2013.
} 
Tabela 1.1: Resumo Tabular das Ferramentas Relacionadas

\begin{tabular}{lccccc}
\hline \hline Ferramentas & Dados & Protocolo & Interface & Rede & Conexão \\
\hline Jacktrip & Áudio & UDP & TUI & WAN & Ponto a ponto \\
Netjack & Áudio / MIDI & UDP & TUI & WAN & Estrela \\
Ninjam & Áudio & TCP & GUI/TUI & ADSL & Estrela \\
jack.udp & Áudio & UDP & UI & LAN & Ponto a ponto \\
llcon & Áudio & UDP & GUI & ADSL & Estrela \\
streamin / streamout $~$ & Áudio & UDP & PD & LAN & Ponto a ponto \\
Qmidinet & Midi & Multicast UDP & ALSA MIDI & LAN & Distribuída \\
SoundJack & Áudio / Vídeo & UDP & GUI & ADSL & Ponto a ponto \\
\hline \hline
\end{tabular}

- Utilizar buffers circulares para sincronização entre a captura de áudio e seu envio, ou entre o recebimento e a reprodução(JackTrip, SoundJack);

- Diminuir o formato das amostras (16 bits, 8 bits) para reduzir o volume de dados transmitidos (streamin / streamout , Jacktrip);

- Informar o formato de áudio durante a transmissão (streamin / streamout );

- Utilizar redundância na transmissão para garantir a entrega de dados (Jacktrip);

- Adicionar latência proposital para evitar jitter (Ninjam);

- Utilizar Multicast no envio para vários clientes (Qmidinet);

- Utilizar mixagem no envio para diminuir o consumo de rede (llcon);

- Enviar informações temporais para sincronizar relógios e medir latência e jitter (Netjack, Soundjack).

Estas características serão abordadas em mais detalhes no Capítulo 2.

\subsection{Objetivos e Estrutura do Trabalho}

As ferramentas relacionadas trazem soluções que resolvem algumas dificuldades encontradas no escopo desta pesquisa, porém, possuem algumas limitações. A primeira limitação é o fato de que estas ferramentas são implementadas de maneira monolítica, o que dificulta a sua extensão e a integração de novas funcionalidades. Uma segunda limitação é o fato destas ferramentas possuírem um cenário de aplicação associados de maneira indireta à implementação das mesmas. Isto pode ser notado devido ao tipo de protocolos utilizados (TCP e UDP), e em alguns casos o tipo de conexão específico, como conexões centradas em servidor ou conexões apenas entre dois nós. Tal decisão de implementação dificultaria a utilização de tais ferramentas em outros cenários de aplicação. Uma terceira limitação é o fato de terem sido desenvolvidas baseadas em uma única API de som, sendo que em algumas delas esta API é específica para o sistema operacional Linux, dificultando sua integração a outras ferramentas e sistemas operacionais. Além disto, grande parte destas ferramentas lida apenas com um tipo de dado específico, como áudio ou MIDI, e não podem ser facilmente modificadas para dar suporte a outros tipos de dados.

É objetivo deste trabalho transpor estas limitações e agregar as soluções encontradas em uma mesma ferramenta, na forma de um ambiente distribuído para música. Conscientes de que uma única ferramenta dificilmente conseguiria resolver todas estas limitações, nos propomos neste trabalho a desenvolver uma biblioteca para distribuição de conteúdo musical em redes, e sobre esta biblioteca desenvolver ferramentas específicas que possam ser integradas em um mesmo ambiente musical. Desta maneira, o desenvolvimento poderá ser continuado, não se limitando às ferramentas aqui desenvolvidas, o que garantirá uma maior flexibilidade para a integração de novas ferramentas. Nesta direção, os objetivos específicos do projeto são:

- Pesquisar e comparar o uso de diferentes protocolos de rede e arquiteturas de áudio que permitam a integração de aplicativos por redes de computadores. 
- Propor uma arquitetura de referência para o desenvolvimento de aplicações musicais.

- Construir uma biblioteca (denominada libmedusa) para o gerenciamento e distribuição de conteúdo musical em rede.

- Integrar a libmedusa a aplicações populares de produção musical, como Puredata e Ardour, através de plugins ou externals.

- Garantir facilidade de uso para o usuário leigo, através de controles que permitam ao usuário lidar com a heterogeneidade (da rede e das aplicações musicais) de maneira transparente.

- Disponibilizar a biblioteca e as ferramentas como FLOSS (Free/Libre/Open-Source Software).

Este trabalho está organizado da seguinte forma: O Capítulo 2 apresenta a fundamentação teórica, relativa ao desenvolvimento de aplicações musicais e em rede, e a metodologia do trabalho. O Capítulo 3 traz a arquitetura proposta, estruturada nas camadas de rede, controle e aplicação. O Capítulo 4 trata da implementação da Medusa, em particular das camadas de rede e controle na forma da biblioteca libmedusa e das aplicações, que compreendem interfaces com o usuário e com outras aplicações, bem como ferramentas de monitoramento do ambiente. O Capítulo 5 descreve as avaliações realizadas e os resultados obtidos, no que diz respeito aos protocolos de transporte e conectores de áudio e MIDI, bem como discussões relacionadas. O texto termina no Capítulo 6 com as conclusões e os trabalhos futuros. 


\section{Capítulo 2}

\section{Fundamentação teórica e metodologia}

Para propiciar ao leitor um melhor entendimento deste texto, apresentaremos nesta Seção conceitos relacionados ao desenvolvimento de aplicações musicais e ao desenvolvimento de aplicações em rede. Após apresentar estes conceitos apresentaremos a metodologia aplicada neste trabalho.

\subsection{Desenvolvimento de Aplicações Musicais}

O desenvolvimento de aplicações musicais inclui o conhecimento de alguns conceitos de representação simbólica de notações musicais em computadores e também o processamento de sinais de áudio e sinais musicais. Faremos nesta Seção uma breve apresentação dos principais conceitos que serão utilizados neste texto.

\subsubsection{Representação de Áudio}

Para que seja possível a manipulação do som pelo computador é necessário o uso de uma representação digital do sinal sonoro, que representa a variação de pressão sonora em função do tempo, em um certo ponto do espaço. Para isto, utilizamos circuitos conversores analógico-digitais $(\mathrm{ADC})$, que permitem a representação digital do som de várias formas. Uma destas formas ${ }^{1}$ é chamada Pulse Code Modulation (PCM) e substitui o sinal original por uma sequência de valores inteiros associados às amostras do sinal original [Moo90].

A conversão de um sinal analógico para o formato PCM ocorre por meio de uma amostragem do sinal. A cada intervalo de tempo fixado o valor instantâneo do sinal analógico é capturado e representado por um valor computacional. A precisão da representação de um sinal depende de dois fatores: A quantidade de amostras por intervalo de tempo (taxa de amostragem) e o tamanho (em bits) da representação de cada amostra (resolução das amostras ou bit depth). Outros fatores que também influenciam na representação digital do sinal sonoro são o número de canais e a arquitetura do sistema operacional.

\section{Número de Canais}

Devido à capacidade humana de perceber a espacialização do som e a localização de fontes sonoras a partir de seus dois ouvidos, várias estratégias de representação de áudio multi-canal foram exploradas, tanto em âmbito analógico quanto digital. Por exemplo, o áudio de um CD é representado em dois canais (estéreo), para reprodução em alto-falantes ou fones-de-ouvido. A tentativa de melhorar a localização espacial de fontes sonoras guiou as pesquisas e o desenvolvimento de tecnologia para o áudio quadrafônico (4 canais) e surround (5 ou mais canais), por exemplo. Na representação de áudio digital multicanal, o arquivo e/ou fluxo de áudio deve conter todos os canais de forma sequencial, o que implica em diferentes tipos de representação. Uma forma comum para representar o áudio com vários canais é chamada entrelaçada, apresentada na Figura 2.1, onde uma

\footnotetext{
${ }^{1}$ Outras formas de representação são DPCM, PAM, PWM. Recomendamos [Moo90] para maiores detalhes.
} 
amostra de cada canal é disposta sequencialmente; outra forma é a não entrelaçada, apresentada na Figura 2.2.

\begin{tabular}{|l|l|l|l|l|l|l|l|l|l|l|l|l|l|l|l|l|l|}
\hline L & R & L & R & L & R & L & R & L & R & L & R & L & R & L & R & L & $\ldots$ \\
\hline
\end{tabular}

Figura 2.1: Exemplo de Buffer de Áudio Entrelaçado

\begin{tabular}{|l|l|l|l|l|l|l|l|l|l|l|l|l|l|l|l|l|l|}
\hline L & L & L & L & L & L & L & L & L & L & L & L & L & L & L & L & L & $\ldots$ \\
\hline R & R & R & R & R & R & R & R & R & R & R & R & R & R & R & R & R & $\ldots$ \\
\hline
\end{tabular}

Figura 2.2: Exemplo de Buffer de Áudio não Entrelaçado

\section{Formato das Amostras}

Dois parâmetros são fundamentais na definição do formato das amostras de áudio: o número de bits por amostra (resolução ou bit depth) e o tipo de dado associado. Valores comuns para a resolução são 8, 16, 24 e 32 bits, e tipos comuns são códigos inteiros com e sem sinal e ponto flutuante, em distribuição linear ou logarítmica. O CD utiliza amostras inteiras de 16 bits.

A representação digital de uma amostra de áudio irá assumir valores proporcionais aos valores do sinal analógico original, dentro de uma limitação do sinal por valores mínimo e máximo que cada amostra pode assumir. Limites comuns são $\pm 2^{B-1}$ no caso de amostras inteiras com sinal em $B$ bits, e \pm 1.0 no caso de amostras em ponto flutuante.

O formato da amostra não interfere na faixa de frequências representável pelo sinal amostrado, mas interfere na relação sinal-ruído, dado que apenas $2^{B}$ valores estarão disponíveis para a representação de valores (contínuos) de amplitude do sinal analógico original. A resolução das amostras também influencia no tamanho do dado amostrado, e por consequência na quantidade de bits transmitidos por segundo (bitrate).

\section{Inversão de Bytes}

Arquiteturas de computadores distintas podem usar convenções distintas ao representar dados numéricos. Para dados com mais de 1 byte, há duas representações comuns: na representação Big Endian os bytes são sequenciados do mais significativo para o menos significativo, e na representação Little endian os bytes são sequenciados do menos significativo para o mais significativo.

\section{Valor $\quad$ OA OB OC OD

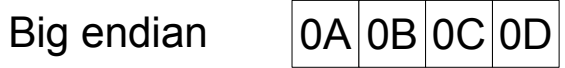 \\ Little endian $\quad$ OD OC OB OA}

Figura 2.3: Exemplo de Representação de Memória (Big Endian / Little Endian)

\section{Taxa de Amostragem}

A taxa ou frequência de amostragem é medida em $\mathrm{Hz}$ (amostras por segundo) e influencia na capacidade de representação de frequências no sinal amostrado, devido ao teorema de ShannonNyquist (que estabelece para as frequências representáveis o limite de metade da taxa de amostragem) e também no tamanho da representação digital do sinal. 
A taxa de amostragem de áudio em CDs é de $44.100 \mathrm{~Hz}$, o que garante a representabilidade de todo o espectro audível (com limites aproximados de $20 \mathrm{~Hz}$ a $20.000 \mathrm{~Hz}$ ). Há conversores que realizam uma amostragem muito superior a esta, permitindo que o sinal possa ser processado digitalmente de diversas maneiras com uma menor degradação de qualidade diminuindo por exemplo o impacto do rebatimento, ou aliasing, de frequências que não seriam representáveis numa taxa de amostragem menor.

\section{Sincronização de Amostras}

A conversão de áudio analógico para digital ocorre em intervalos de tempo regulares de acordo com a taxa de amostragem. Este intervalo de tempo é provido por um relógio presente no conversor, que é responsável por gerar pulsos a partir da vibração de um cristal. Dois circuitos ADC, ainda que idênticos, podem possuir diferenças em sua medição do tempo, devido ao fato de seus cristais vibrarem aproximadamente, mas não exatamente, na mesma frequência. A precisão da amostragem dependerá da precisão da vibração deste cristal e isto influi diretamente na qualidade do áudio amostrado. O desalinhamento das amostras em sinais de áudio causado pela diferença na sincronização de amostragem entre dois circuitos ADC é chamado de world clock drift.

\section{Compactação de Áudio}

O formato PCM, apesar de bastante utilizado, exige que um grande volume de informação seja armazenado ou transmitido para a sua correta decodificação. Para diminuir o tamanho gasto no armazenamento de um sinal, vários algoritmos de compactação foram desenvolvidos. Estes algoritmos dividem-se em dois grandes grupos: compactação sem perda e compactação com perda.

Algoritmos de compactação sem perda permitem a decodificação da informação original de forma exata, e normalmente atingem taxas de compactação modestas, como 50\% (aproximadamente) no caso do formato FLAC. Já os algoritmos de compactação com perda atingem taxas de compactação muito maiores, como $90 \%$ ou mais, eliminando informações que em princípio não afetam drasticamente a qualidade do sinal original, sendo que diversos conceitos de psicoacústica são utilizados para decidir quais informações seriam menos relevantes. Exemplos destes algoritmos são: AAC, OGG, MP3, CELT e ULD.

Independentemente do grupo, todos os algoritmos de compactação produzem sinais de áudio em uma forma diferente da representação PCM, e por isto dependem de poder computacional para a codificação e decodificação, antes que possam ser manipulados ou reproduzidos.

\section{Enjanelamento}

O sinal digital é raramente tratado amostra por amostra, sendo frequentemente processado em blocos ou conjuntos de amostras chamados janelas. Em particular, muitos algoritmos (como a FFT) dependem de um conjunto de amostras para iniciar seu processamento. O enjanelamento é feito tanto em aplicações (software) quanto em dispositivos físicos (hardware) de processamento de áudio digital.

Entretanto, a espera para o agrupamento de amostras em um fluxo em tempo real sempre irá adicionar latência no resultado do processamento. O atraso gerado pelo enjanelamento pode ser calculado em função do tamanho $N$ da janela de amostras e da taxa de amostragem $S R$ do sinal, como $N / S R$ segundos. Por exemplo, em um áudio de CD segmentado em janelas de 512 amostras essa latência de enjanelamento será de aproximadamente $11.61 \mathrm{~ms}$.

\subsubsection{Protocolo MIDI}

MIDI (Musical Instrument Digital Interface) é um dos protocolos mais utilizados para a interconexão de dispositivos musicais eletrônicos, tendo sido amplamente adotado pela indústria de 
software e hardware para música. Proposto como uma rede unidirecional, o MIDI foi provavelmente o primeiro protocolo musical padrão que criou a possibilidade de música em rede [Loy85], integrando diferentes aplicações e dispositivos musicais.

Este protocolo foi originalmente projetado para fornecer uma transmissão de mensagens com baixa latência entre dispositivos [NT04]. Há 5 tipos principais de mensagens MIDI: Channel Voice, Channel Mode, System Common, System Real-Time e System Exclusive (SysEx). Estas mensagens podem ser divididas em 2 grandes grupos: mensagens de canal e mensagens do sistema.

Mensagens de canal são utilizadas para enviar informações para dispositivos MIDI como notas, controles ou o comportamento de um sintetizador. Uma mensagem de sistema é uma mensagem MIDI mais geral que afeta o sistema MIDI como um todo como, por exemplo, reiniciar o sistema, a posição em uma música ou uma sincronização de tempo.

O canal MIDI corresponde a um conceito diferente do canal de áudio. Enquanto em áudio um canal refere-se a um sinal sonoro ou a uma conexão física de áudio, em MIDI um canal diz respeito ao endereçamento da mensagem MIDI. Utilizando este conceito, um sintetizador pode utilizar diferentes canais para endereçar diferentes instrumentos sendo que estas mensagens são enviadas em uma mesma conexão física. O General MIDI, por exemplo, utiliza o canal 10 como endereço padrão de seus instrumentos de percussão. Por serem mais gerais, as mensagens MIDI de sistema não utilizam o endereçamento por canal.

Independentemente do tipo, uma mensagem MIDI pode ter de 1 a 128 bytes, sendo que este tamanho pode variar dependendo do tipo da mensagem. Por exemplo, a mensagem SysEx que requisita a identificação de um dispositivo é respondida com uma mensagem de 15 bytes contendo a identificação (MIDI id) e a versão do protocolo MIDI, entre outros dados.

Além de servir para o transporte de mensagens entre interfaces musicais e sintetizadores, as mensagens MIDI podem controlar diversos dispositivos e equipamentos como mixers e plugins. A especificação do protocolo MIDI ainda inclui:

- O MIDI Machine Control (MMC), que controla gravadores e sequenciadores fornecendo mensagens como Play, Fast Forward, Rewind, Stop, Pause, and Record.

- O MIDI Time Code (MTC), que é um protocolo de tempo que pode ser utilizado para sincronizar dispositivos e aplicações como loopers e sequencers.

- O MIDI Show Control (MSC), que é um protocolo desenvolvido para controlar equipamentos em teatros, apresentações ao vivo, instalações multimídia e outros ambientes similares.

Estas mensagens podem ser utilizadas para sincronizar e controlar aplicações MIDI e dispositivos que normalmente são conectados diretamente. A utilização de fluxos MIDI em rede pode expandir as possibilidades de controle e integração do protocolo MIDI em um ambiente de rede distribuído para processamento de som.

\subsubsection{APIs para o Desenvolvimento de Aplicações Musicais}

Uma API (Aplication Programming Interface) é uma série de funções e rotinas estabelecidos por uma aplicação que permite o acesso a suas funcionalidades sem que seja necessário o conhecimento de seu funcionamento interno ou de seus detalhes de implementação.

Há várias maneiras de implementar aplicações para processamento de som que diferem pelo tipo da API de áudio utilizada. Organizamos algumas destas APIs em uma arquitetura em camadas apresentada na Figura 2.4.

O nível mais baixo de API que pode ser utilizado é a API do sistema operacional. Utilizar a API do sistema operacional para desenvolver uma aplicação implica em restringi-la a esse sistema operacional e geralmente cria dificuldades para a portabilidade da aplicação. A portabilidade de um sistema é a capacidade de o mesmo trabalhar em várias arquiteturas de computadores e/ou vários sistemas operacionais. Para facilitar a portabilidade entre aplicações e APIs de áudio do 


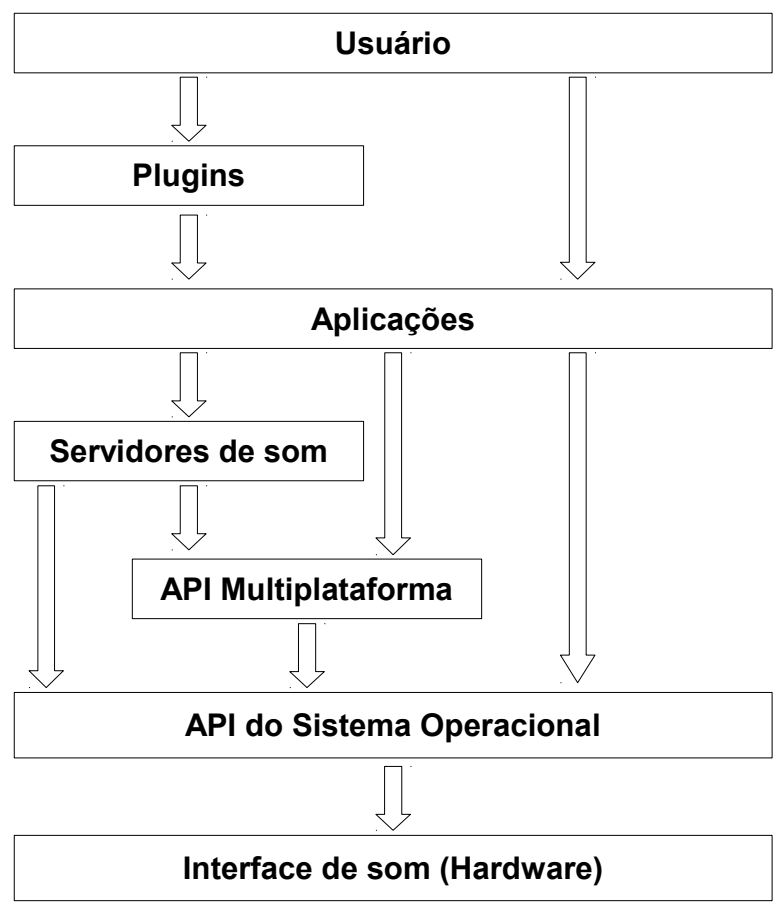

Figura 2.4: Camadas de API de Áudio

sistema operacional, surgiram APIs portáveis que permitem o desenvolvimento de aplicativos para vários sistemas operacionais.

Além da portabilidade, é desejável que as aplicações de áudio se comuniquem com aplicações já existentes. Caso isto seja possível, podemos tratar o desenvolvimento de aplicações de áudio como o desenvolvimento de pequenos módulos que possam se acoplar criando outras aplicações. Várias aplicações de áudio aceitam extensões modulares por meio de plugins. Também é possível criar aplicações modulares para áudio utilizando um servidor de som.

\section{APIs de Áudio do Sistema Operacional}

A primeira camada que nos permite desenvolver aplicações de áudio é a API fornecida pelo sistema operacional por meio do driver da interface de som. É possível desenvolver aplicações diretamente sobre esta camada, porém a mesma será dependente do sistema operacional cuja API foi utilizada. Esta dependência não apenas impede a portabilidade da aplicação mas também pode exigir muita refatoração de código com a evolução do sistema operacional. Isto ocorre pois há variações de API em versões diferentes do mesmo sistema operacional.

Exemplos desta camada de driver no Windows são o DirectSound, Windows Multimedia Extensions (MMEd), WinKS, WASAPI, Windows Multimedia Library e ASIO. Em Linux há o FFADO, ALSA e OSS além de variações de servidores de som como o ESD e o arts. No MacOS há versões com o Apple Sound Manager (SM), ASIO e Apple Core Audio.

\section{APIs Multiplataforma}

Visando simplificar a portabilidade de aplicações, foram desenvolvidas bibliotecas que permitem a implementação de uma aplicação sobre várias APIs de áudio do sistema operacional. Exemplos destas APIs multiplataforma são: JUCE, SDL, OpenAL, RTAudio e PortAudio.

As APIs OpenAL e SDL possuem uma especificação voltada para jogos e por isto possuem amplo suporte para espacialização. Porém, o fato de não possuírem acesso a dispositivos MIDI pode limitar a utilização das mesmas em aplicações musicais que necessitem deste suporte. A presença de suporte ao MIDI no JUCE, PortAudio e RtAudio mostra que estas APIs foram desenvolvidas tendo em vista aplicações de contexto musical. 


\section{Servidores de Som}

Servidores de som adicionam uma camada a mais no sistema de comunicação entre a aplicação de áudio e o hardware correspondente. Isto elimina a necessidade de comunicação da aplicação com o driver ou a API do sistema operacional, já que o servidor de som é responsável por tal comunicação. Entre os servidores de som, destacam-se o JACK, Pulse Audio, Sound Flower, Rewire (proprietário da Propellerheads) e DirectConnect (proprietário da Digidesign).

O JACK (JACK Audio Connection Kit)tornou-se o servidor de som mais utilizado para aplicações musicais profissionais em ambientes Linux e recentemente levou a sua capacidade de interoperabilidade entre ferramentas para outros sistemas operacionais, como Windows e Mac OS.

O Pulseaudio propõe uma solução elegante de servidor de som multiplataforma, sendo a API padrão para aplicações musicais em sistemas Linux. Porém o Pulseaudio não suporta a conexão de fluxos de áudio entre aplicações, o que impede considerá-lo como servidor de som para o desenvolvimento de aplicações modulares.

O SoundFlower possui uma boa solução para interconexão de aplicativos, mas seu uso é restrito ao Mac OS, sem planos de portabilidade para outras plataformas.

Por estas razões consideramos o JACK como o servidor de som por excelência para aplicações musicais profissionais multiplataforma.

\section{Plugins}

Muitas ferramentas são feitas de forma extensível por meio de plugins. Plugins de áudio podem ser integrados diretamente a ferramentas de alto nível como Audacity, Ardour, ProTools, Cubase, Rosegarden e Traverso, entre outras.

O software que permite sua extensão por plugins é chamado de host ou hospedeiro do plugin. Um host pode aceitar uma ou mais arquitetura de plugins. Entre as arquiteturas de plugins de áudio disponíveis atualmente podemos citar: LADSPA, DSSI, LV2, Audio Unit, RTAS, VST / VSTi e DirectX.

As tecnologias de plugins estão ainda muito atreladas a um sistema operacional ou ferramenta específica. Por esta razão, desenvolver um plugin para um host específico limita a escolha a uma API que seja compatível com este host.

\section{Escolha da API de Áudio}

A escolha de uma determinada API para o desenvolvimento de uma aplicação irá influenciar diretamente na capacidade desta aplicação em interagir com outras ferramentas. Além disto, outros fatores podem influenciar a escolha de uma API como, por exemplo, suporte a áudio e/ou MIDI, portabilidade da aplicação, disponibilidade da API em determinado sistema operacional, latência pretendida e precisão. Outro fator preponderante na escolha da API é sua licença de distribuição, pois isto traz implicações diretas sobre a distribuição da aplicação desenvolvida.

Mais detalhes sobre APIs de áudio e desenvolvimento de aplicações sobre estas APIs podem ser encontrados em [SQB12].

\subsection{Desenvolvimento de Aplicações em Rede}

As redes de computadores se tornaram uma ferramenta comum para usuários de sistemas computacionais, muito embora o conhecimento técnico desta ferramenta não seja necessário para sua utilização cotidiana. Desde as questões físicas de uma conexão aos protocolos utilizados nesta conexão, diversos aspectos técnicos trazem possibilidades distintas para o tráfego de conteúdo musical utilizando redes de computadores. 


\subsubsection{Pilha de Protocolos TCP/IP}

O conjunto de protocolos TCP/IP, criado como um modelo em camadas chamado pilha de protocolos TCP/IP, está constantemente sendo ampliado e estendido [Com00]. Esta separação em camadas permite uma divisão do trabalho e simplifica a implementação de protocolos alternativos aos já definidos $\left[\mathrm{PBD}^{+} 06\right]$. A pilha TCP/IP é apresentada na Figura 2.5.

\begin{tabular}{c|c|l}
\cline { 2 - 3 } Espaço de Usuário & Aplicação & HTTP, FTP, ... \\
\hline \multirow{2}{*}{ Espaço de kernel } & Transporte & TCP, UDP, SCTP, DCCP, ... \\
\cline { 2 - 2 } & Rede & IP, ICMP, IGMP, ... \\
\cline { 2 - 2 } & Enlace & Driver do dispositivo \\
\cline { 2 - 2 } & Física & \\
&
\end{tabular}

Figura 2.5: Camadas da Pilha de Protocolos TCP/IP Baseada em Figura de [KR00]

Os sistemas operacionais modernos possuem uma separação entre processos que ocorrem no nível do usuário e processos que são executados no nível do sistema operacional (kernel). Os protocolos de aplicação são processos de usuários enquanto os protocolos de transporte e demais camadas inferiores são normalmente parte do núcleo do sistema operacional [SFR03]. Isto significa que qualquer novo protocolo de aplicação pode ser criado e implementado, enquanto um protocolo de transporte deve ser fornecido pelo sistema operacional, e seu desenvolvimento e instalação dependem de privilégios administrativos.

\section{Camada de Rede: Internet Protocol (IP)}

O IP é o protocolo de rede mais utilizado da pilha TCP/IP pois praticamente todos os dados de usuários trafegados em redes IP são empacotados por este protocolo [Ste94]. O pacote de dados IP é chamado datagrama e os dados são empacotados com um cabeçalho IP. Além do empacotamento dos dados provenientes da camada de transporte, a camada de rede é também responsável pelo endereçamento dos pacotes.

O tamanho normal de um cabeçalho IP é de 20 bytes, a menos que alguma opção esteja presente, como mostra a Figura 2.6. Com opções e informações IPV6 o tamanho de um cabeçalho de datagrama IP pode chegar a 60 bytes $\left[\mathrm{PBD}^{+} 06\right]$.

\begin{tabular}{|c|c|c|c|c|}
\hline $\begin{array}{c}4 \text { bit } \\
\text { versão }\end{array}$ & $\begin{array}{r}4 \text { bit } \\
\text { Tam. cabe }\end{array}$ & $\begin{array}{c}8 \text { bit } \\
\text { Tipo de serviço }\end{array}$ & \multicolumn{2}{|r|}{$\begin{array}{l}16 \text { bit (in byte) } \\
\text { Tamanho total }\end{array}$} \\
\hline \multicolumn{3}{|c|}{$\begin{array}{c}16 \text { bit } \\
\text { Identificação }\end{array}$} & $\begin{array}{l}3 \text { bit } \\
\text { flags }\end{array}$ & $\begin{array}{c}13 \text { bit } \\
\text { Offset fragmento }\end{array}$ \\
\hline Tem & $\begin{array}{l}8 \text { bit } \\
\text { npo de vida }\end{array}$ & $\begin{array}{c}8 \mathrm{bit} \\
\text { Protocolo }\end{array}$ & \multicolumn{2}{|c|}{$\begin{array}{c}16 \text { bit } \\
\text { Verificação do cabeçalho }\end{array}$} \\
\hline \multicolumn{5}{|c|}{$\begin{array}{l}32 \text { bit } \\
\text { Endereço IP do remetente }\end{array}$} \\
\hline \multicolumn{5}{|c|}{$\begin{array}{c}32 \text { bit } \\
\text { Endereço IP do destinatário }\end{array}$} \\
\hline \multicolumn{5}{|c|}{$\begin{array}{c}\text { Opções } \\
\text { (se existirem) }\end{array}$} \\
\hline \multicolumn{5}{|c|}{ Dados } \\
\hline
\end{tabular}

Figura 2.6: Formato de um Datagrama IP Baseada em Figura de [Ste94]

Além de encapsular os dados para o envio, o IP possui duas características importantes: Medição de MTU e TTL. O MTU é a unidade máxima de transmissão em uma camada física. Se o protocolo IP possui um dado maior que o MTU para ser enviado, este dado será fragmentado em dois ou mais datagramas de forma que cada fragmento seja menor que o MTU [Ste94]. Se um datagrama 
tem que ser fragmentado, ele terá um maior custo de envio pois cada fragmento será empacotado com um cabeçalho IP. O protocolo IP é implementado independentemente da camada física e por isto o MTU pode assumir qualquer valor. Todavia, o tamanho de 1500 bytes utilizado pelo padrão ethernet é adotado comumente como tamanho padrão, sendo este frequentemente o limite superior de tamanho para um datagrama IP [Tan02].

O TTL é o tempo de vida de um pacote de rede, medido em número de hops ou pontos de retransmissão. Se um datagrama é enviado e seu tempo de vida extrapola o permitido, um dispositivo no caminho do pacote irá simplesmente ignorá-lo e descartá-lo da fila de envio. Esta característica está diretamente associada à perda de pacotes de uma aplicação, pois o protocolo IP não possui outros mecanismos de controle, e simplesmente envia todos os pacotes dentro do limite imposto pelo TTL.

\section{Camada de Transporte}

Vários protocolos existem na camada de transporte, dada a diversidade de cenários específicos na camada de aplicação, cada qual mais adequado a um certo conjunto de cenários de aplicação. Apresentaremos resumidamente a seguir os protocolos de transporte UDP, TCP, SCTP e DCCP .

\section{User Datagram Protocol (UDP)}

O UDP é um protocolo de transporte bastante simples na pilha de protocolos TCP/IP. Assim como o IP, uma mensagem UDP é chamada de datagrama. O protocolo UDP simplesmente encapsula os dados de uma aplicação com seu cabeçalho de 8 bytes, apresentado na Figura 2.7[Ste94]. O UDP é considerado um protocolo levíssimo com um modelo de serviço minimalista, que faz pouco mais que simplificar a demultiplexação de mensagens para a camada de aplicação [KR00, PD03].

\begin{tabular}{|c|c|}
\hline $\begin{array}{c}16 \text { bit } \\
\text { No. da porta de origem }\end{array}$ & $\begin{array}{c}16 \text { bit } \\
\text { No. da porta destino }\end{array}$ \\
\hline $\begin{array}{c}16 \text { bit } \\
\text { Tamanho do UDP }\end{array}$ & $\begin{array}{c}16 \text { bit } \\
\text { Verificação do UDP }\end{array}$ \\
\hline \multicolumn{2}{|c|}{$\begin{array}{c}\text { Dados } \\
\text { (se existir) }\end{array}$} \\
\hline
\end{tabular}

Figura 2.7: Formato de um Datagrama UDP Baseada em Figura de [Ste94]

Como um datagrama IP, a mensagem UDP pode ser perdida, duplicada ou desordenada na entrega [Com00]. Mesmo assim, o UDP não possui nenhum mecanismo para recuperação de dados perdidos, ordenação de mensagens ou eliminação de mensagens duplicadas. É por estas razões que este protocolo é chamado de não confiável. A única garantia que um datagrama UDP possui é sua verificação de integridade de conteúdo (checksum). O checksum irá garantir que o conteúdo do datagrama é consistente. Todavia, a especificação do UDP não prevê o que é feito caso um pacote recebido não esteja íntegro, pois este protocolo não prevê a retransmissão de pacotes. Assim, as aplicações que utilizam o UDP devem estar preparadas para tratarem de recuperação de erro, falha de integridade, perda de pacotes, reordenação de pacotes, controle de fluxo, controle de congestionamento e assim por diante [DC09], caso seja necessário.

Na aplicação que utiliza UDP, cada operação de saída de um processo produz exatamente um datagrama UDP que pode ocasionar vários datagramas IP para o envio, dependendo do MTU da camada física. Teoricamente, o tamanho máximo de um datagrama IP é de 65535 bytes [Ste94]. Embora muitas implementações aceitem pacotes maiores, todas as implementações são obrigadas a aceitar datagramas IPs de 576 bytes. Isto significa que 8 bytes serão usados pelo cabeçalho UDP, 60 bytes serão usados pelo cabeçalho IP (tamanho máximo) e a aplicação pode enviar apenas 508 bytes $\left[\mathrm{PBD}^{+} 06\right]$. 
Finalmente, o UDP não possui protocolo de ligação (handshaking) ou mensagens de confirmação de recebimento (ACK), nem handshaking de início de transmissão ou de final de transmissão. Por isto não há como uma aplicação saber se um pacote foi corretamente enviado ou se um cliente ainda está conectado a um servidor, cabendo à aplicação implementar tais mensagens caso necessário [KR00].

\section{Transmission Control Protocol (TCP)}

O TCP é o protocolo de transporte confiável clássico do conjunto TCP/IP. Como o TCP é um protocolo de fluxo de bytes, o destinatário irá receber segmentos de dados. Por esta razão, a mensagem TCP é chamada de segmento. Cada segmento é um pacote com um cabeçalho de 20 bytes, como apresentado na Figura 2.8 .

\begin{tabular}{|c|c|c|}
\hline No. da po & $\begin{array}{l}16 \text { bit } \\
\text { orta de origem }\end{array}$ & $\begin{array}{l}16 \text { bit } \\
\text { No. da porta destino }\end{array}$ \\
\hline \multicolumn{3}{|c|}{$\begin{array}{l}32 \text { bit } \\
\text { Número sequencial }\end{array}$} \\
\hline \multicolumn{3}{|c|}{$\begin{array}{c}32 \text { bit } \\
\text { Número de conhecimento (ACK) }\end{array}$} \\
\hline \begin{tabular}{|c|}
4 bit \\
Tam. cabeçalho
\end{tabular} & \begin{tabular}{|c|c|c|c|c|c|}
6 bit & $U$ & $A$ & $P$ & $R$ & $S$ \\
reservado & $\mathrm{F}$ & $\mathrm{C}$ & $\mathrm{S}$ & $\mathrm{Y}$ & $\mathrm{I}$ \\
$\mathrm{G}$ & $\mathrm{K}$ & $\mathrm{H}$ & $\mathrm{T}$ & $\mathrm{N}$ & $\mathrm{N}$ \\
\end{tabular} & $\begin{array}{c}16 \text { bit } \\
\text { Tamanho da janela }\end{array}$ \\
\hline Verific & $\begin{array}{l}16 \text { bit } \\
\text { icação TCP }\end{array}$ & $\begin{array}{c}16 \text { bit } \\
\text { TCP urgente }\end{array}$ \\
\hline \multicolumn{3}{|c|}{$\begin{array}{l}\text { Opções } \\
\text { (se existir) }\end{array}$} \\
\hline \multicolumn{3}{|c|}{$\begin{array}{l}\text { Dados } \\
\text { (se existir) }\end{array}$} \\
\hline
\end{tabular}

Figura 2.8: Formato do Segmento TCP Baseada em Figura de [Ste94]

O TCP provê um serviço orientado a conexão, confiável e de fluxo [Ste94]. Para fornecer confiabilidade, a comunicação TCP utiliza os seguintes mecanismos:

1. MSS: O tamanho máximo de dados enviado pelo TCP é chamado de Tamanho máximo de segmento (Maximum Segment Size - MSS). Para enviar um segmento, o TCP pode acumular em um segmento dados de várias chamadas de uma aplicação à função write, ou dividir os dados de um write em múltiplos segmentos. Por esta razão, o número de dados recebidos pelo destinatário pode não ser o mesmo que o enviado pelo remetente [PD03]. Quando uma conexão é estabelecida os pares podem informar seu MSS [Ste94]. Este tipo de controle de dado serve para evitar que um nó sobrecarregue seu destinatário com dados grandes demais para que o mesmo consiga processá-los. Toda comunicação TCP depende desta concordância quanto à quantidade de dados que será transmitida.

2. ACK: Quando o destinatário TCP recebe um segmento ele envia ao remetente uma mensagem de confirmação (ACK), informando que o segmento foi recebido corretamente.

3. Tempo limite de ACK: O TCP mantém um temporizador para cada segmento enviado, esperando que o destinatário envie uma mensagem ACK. Se o ACK não for recebido a tempo, o segmento é retransmitido.

4. Checksum: Como o UDP, o TCP tem um campo para verificação em seu cabeçalho para verificar se a mensagem foi corrompida ou não. O TCP irá descartar um segmento que possua Checksum inválido e não irá enviar um ACK no recebimento deste segmento. Feito isto, espera-se que o remetente retransmita este segmento quando seu temporizador à espera deste ACK atingir seu tempo limite. 
5. Buffer: Independentemente de MSS, o segmento TCP irá ser transportado por um datagrama IP e deverá ser ajustado ao tamanho máximo do IP [Tan02]. Como o datagrama IP pode ser transmitido fora de ordem, o destinatário TCP tem que ordenar os dados recebidos, garantindo que todo dado recebido pela camada de aplicação estará ordenado. O número sequencial no cabeçalho TCP é utilizado para este fim e também para descartar possíveis segmentos duplicados, independentemente desta duplicação ter ocorrido por duplicação de datagramas ou por um reenvio errôneo de um segmento.

6. Controle de fluxo: Cada par em uma conexão TCP possui um espaço de buffer finito. Assim, um destinatário informa para o remetente TCP quanto de espaço em buffer ele possui para receber dados, evitando assim sobrecarregar sua capacidade.

7. Controle de congestionamento: Enquanto o controle de fluxo é um acordo entre pares, o controle de congestionamento se preocupa com a capacidade do caminho de rede entre os pares (cabo, switchs, hubs, routers, ...). Este controle evita que o TCP envie mais dados que a rede pode suportar [PD03].

Como um protocolo orientado a conexões, o TCP utiliza um mecanismo com três passos para estabelecer uma conexão, sendo este mecanismo completamente transparente para os programas clientes e servidores [KR00].

Devido à confiabilidade do TCP, sua conexão é sempre ponto-a-ponto. Uma comunicação Multicast que envia dados para vários destinatários não é suportada pelo TCP [KR00].

\section{Stream Control Transmission Protocol (SCTP)}

O SCTP é um protocolo de transporte orientado a conexão que provê uma associação full-duplex confiável para o transporte de multifluxos [SFR03]. Este protocolo foi originalmente desenvolvido para transporte de voz sobre IP (VoIP) sem ter a intenção de substituir o TCP como um protocolo confiável. O pacote SCTP contém um cabeçalho fixo de 12 bytes além de um cabeçalho de 4 bytes para cada unidade de informação (chunk), conforme apresentado na Figura 2.9. Cada chunk contém seu próprio cabeçalho com o tipo de dados, flags e tamanho [SFR03].

\begin{tabular}{|c|c|c|}
\hline \multicolumn{2}{|c|}{$\begin{array}{c}16 \text { bit } \\
\text { Número da porta de origem }\end{array}$} & $\begin{array}{c}16 \text { bit } \\
\text { No. da porta destino }\end{array}$ \\
\hline \multicolumn{3}{|c|}{$\begin{array}{l}32 \text { bit } \\
\text { Etiqueta de verificação }\end{array}$} \\
\hline \multicolumn{3}{|c|}{$\begin{array}{c}32 \text { bit } \\
\text { Verificação (checksum) }\end{array}$} \\
\hline $\begin{array}{c}8 \text { bit } \\
\text { Tipo do Chunk \#1 }\end{array}$ & $\begin{array}{c}8 \text { bit } \\
\text { Flag do Chunk \#1 }\end{array}$ & $\begin{array}{c}16 \text { bit } \\
\text { Tamanho do Chunk \#1 }\end{array}$ \\
\hline \multicolumn{3}{|c|}{ Dados do Chunk \#1 } \\
\hline \multicolumn{3}{|c|}{$\ldots$} \\
\hline $\begin{array}{c}8 \text { bit } \\
\text { Tipo do Chunk \#N }\end{array}$ & $\begin{array}{c}8 \text { bit } \\
\text { Flag do Chunk \#N }\end{array}$ & $\begin{array}{c}16 \text { bit } \\
\text { Tamanho do Chunk \#N }\end{array}$ \\
\hline \multicolumn{3}{|c|}{ Dados do Chunk \#N } \\
\hline
\end{tabular}

Figura 2.9: Formato do Chunk SCTP Baseada em Figura de [HP08]

A confiabilidade do SCTP é fornecida a partir das seguintes características:

1. Multihoming: O SCTP fornece associações entre clientes e servidores. A palavra "associação" é utilizada em vez de "conexão" porque ela pode envolver mais de dois endereços em 
multihoming. Esta característica pode fornecer mais garantia em relação a falhas de redes, através do estabelecimento de várias conexões de rede redundantes, cada uma com uma conexão diferente com a infraestrutura de Internet. Isso permite ao SCTP contornar uma falha de rede alterando o endereço de envio/recebimento em uma associação SCTP [SFR03].

2. Fluxos Múltiplos: O SCTP pode fornecer vários fluxos em uma única conexão, cada um com suas próprias mensagens de entrega confiável. Se uma mensagem é perdida em um dos fluxos, o SCTP não bloqueia a entrega das mensagens de qualquer um dos outros fluxos [SFR03].

3. Fragmentação na camada de transporte: O SCTP mantém um ponto de fragmentação baseado no menor MTU encontrado no caminho entre dois pares, e este menor MTU é utilizado para fragmentar mensagens grandes em pedaços menores que podem ser enviados em um único datagrama IP [SFR03]. Como o TCP e diferentemente do UDP, esta fragmentação ocorre na camada de transporte e não na camada de rede.

4. Retransmissão rápida: O SCTP, tal como o TCP, utiliza mensagens ACK para informar perdas de pacotes. Porém, ao contrário do TCP e de ACKs normais, ele utiliza ACK seletivos (SACK) e um mecanismo que envia mensagens SACK mais rapidamente que o normal quando perdas são detectadas $\left[\mathrm{PBD}^{+} 06\right]$.

5. Cabeçalhos não bloqueantes: Ao contrário do TCP que é baseado unicamente em fluxos, o SCTP é orientado a mensagens como o UDP. Isto permite que o SCTP separe diferentes mensagens de sinalização na própria camada de transporte. Com isto, o SCTP pode entregar mensagens de sinalização para a aplicação logo que as mesmas forem recebidas $\left[\mathrm{PBD}^{+} 06\right]$.

O SCTP, como o TCP, também fornece confiabilidade, sequenciamento, controle de fluxo, controle de congestionamento, e transferência full-duplex por meio de gerenciamento de rota de entrega, verificação de erros, validação de pacotes e mensagens de sinalização [SFR03].

Existem dois tipos de implementação para um socksocketet SCTP: sockets um-para-um e sockets um-para-muitos. É importante notar que a implementação SCTP de um-para-muitos não equivale a Broadcasting ou Multicasting mas a várias associações para a mesma conexão. Um socket umpara-um corresponde exatamente a uma associação SCTP.

\section{Datagram Congestion Control Protocol (DCCP)}

O DCCP é um protocolo de transporte que combina controle de congestionamento TCP-friendly com uma semântica de datagramas não-confiáveis para aplicações que transferem grandes quantidades de dados [LK05, KHF06]. Ele utiliza um cabeçalho mínimo de 12 bytes como mostrado na Figura 2.10 [BE07].

\begin{tabular}{|c|c|c|c|c|}
\hline \multicolumn{3}{|c|}{16 bit } & \multicolumn{1}{c|}{$\begin{array}{c}16 \text { bit } \\
\text { No. da porta de origem }\end{array}$} & No. da porta destino \\
\hline $\begin{array}{c}4 \text { bit } \\
\text { Tipo }\end{array}$ & $\begin{array}{c}4 \text { bit } \\
\text { CCVal }\end{array}$ & \multicolumn{3}{|c|}{$\begin{array}{c}\text { Número sequencial } \\
24 \text { bit }\end{array}$} \\
\hline $\begin{array}{c}8 \text { bit } \\
\text { Deslocamento de dados }\end{array}$ & $\begin{array}{c}4 \text { bit } \\
\text { \# NDP }\end{array}$ & $\begin{array}{c}4 \text { bit } \\
\text { Cslen }\end{array}$ & $\begin{array}{c}16 \text { bit } \\
\text { Validação }\end{array}$ \\
\hline \multicolumn{4}{|c}{ Dados } \\
\hline
\end{tabular}

Figura 2.10: Formato do Datagrama DCCP Baseada em Figura de [KHF03]

O DCCP pode utilizar ACKs e não trata erros de validação como problemas de congestionamento de rede. Como o DCCP não utiliza retransmissão, o mecanismo de recuperação rápida 
(fast-recovery) do TCP não é implementado [BUB ${ }^{+}$08]. Este protocolo é implementado para aplicações sensíveis a atrasos que preferem pontualidade a confiança. Diferentemente do UDP, que não possui esta característica, o DCCP irá evitar colapsos de congestionamento. Isto porque este protocolo visa adicionar ao UDP um mecanismo mínimo para suportar controle de congestionamento, tal como transmissão confiável de informação de ACK [KHF03].

O DCCP, tal qual o TCP, fornece uma conexão simples direcional e Unicast: tanto os dados quando os ACKs podem ser enviados em ambas as direções. No começo de uma conexão os pares devem concordar em um conjunto de parâmetros como, por exemplo, qual mecanismo de controle de congestionamento será usado [KHF03].

\section{Resumo dos Protocolos de Transporte e Discussão}

A Tabela 2.1 apresenta de maneira tabular algumas características dos protocolos de transporte vistos previamente.

Tabela 2.1: Tabela Comparativa de Protocolos de Transporte

\begin{tabular}{lcccc}
\hline \hline Feature & UDP & TCP & SCTP & DCCP \\
\hline Orientado a mensagem & Sim & Não & Sim & Sim \\
Orientado a conexão & Não & Sim & Sim & Sim \\
Full duplex & Sim & Sim & Sim & Sim \\
Transferência confiável & Não & Sim & Sim & Não \\
Entrega ordenada & Não & Sim & Sim & Não \\
Entrega desordenada & Sim & Não & Sim & Sim \\
Controle de fluxo & Não & Sim & Sim & Não \\
Controle de congestionamento & Não & Sim & Sim & Sim \\
Multicasting & Sim & Não & Não & Não \\
Broadcasting & Sim & Não & Não & Não \\
Descoberta de MTU & Não & Sim & Sim & Não \\
Fragmentação & Não & Sim & Sim & Não \\
Checksum & Sim & Sim & Sim & Sim \\
Tamanho do cabeçalho (em bytes) & 12 & 20 & 12 & 12 \\
\hline \hline
\end{tabular}

Entre os protocolos disponíveis na camada de transporte, muitos livros de redes de computadores sugerem que os fluxos de áudio sejam um caso típico de uso do protocolo UDP. O uso deste protocolo é notado em vários trabalhos relacionados apresentados na Seção 1.2. O uso do protocolo UDP para este cenário de aplicações é defendido baseando-se em um certo nível de tolerância em relação à perda de pacotes e intolerância em relação à latência da rede.

Assim, alguns autores defendem que a perda de dados não é um empecilho crucial para o envio de áudio porque isto resultaria apenas em pequenos ruídos no som que não comprometeriam a inteligibilidade do mesmo (nota-se aqui a adoção de uma métrica específica de voz e não de música). Tal visão não pode ser tomada como regra, pois diferentes cenários podem permitir ou exigir outro balanceamento entre perda de pacotes e latência. A latência é definitivamente uma característica muito importante, principalmente para cenários onde é necessário interação[Sch11].

Outro protocolo comumente sugerido para fluxos de áudio em rede é o RTP [GS96]. Este é um protocolo da camada de aplicação montado sobre o protocolo de transporte UDP, com a adição de números sequenciais para controlar a perda de pacote e instantes de tempo para verificar latência. O protocolo RTP é acompanhado pelo protocolo RTCP (Real Time Control Protocol) [Win07], um protocolo de controle utilizado para fornecer confiabilidade ao RTP. Outro protocolo de aplicação utilizado para fluxos de áudio é o RTSP (Real Time Stream Protocol) [SRL98]. O RTSP é considerado como uma solução para o envio de fluxos sob demanda, pois nele há implementações de comandos como START, PAUSE e TEARDOWN. 


\subsubsection{Modos de Endereçamento}

Os modos (também chamados de métodos ou metodologias) de endereçamento são as associações entre o endereço de origem e destino em uma rede de computadores. Em uma comunicação de rede, estes endereçamentos podem ser de um-para-um ou de um-para-muitos. Um endereçamento um-para-um é chamado de Unicast e é definido como uma conexão de forma que um emissor pode enviar dados para apenas um receptor em uma transmissão. O endereçamento Broadcast e Multicast utilizam um endereçamento de um-para-muitos onde um emissor pode alcançar vários receptores em uma mesma transmissão de dados.

\section{Unicast Simples}

A comunicação Unicast é ponto-a-ponto. Em uma conexão Unicast simples, um servidor possui apenas um cliente, que precisa saber o endereço do servidor para se conectar; o servidor pode, caso necessário, conhecer o endereço do cliente quando o cliente se conecta. Esta conexão é apresentada na Figura 2.11 (a).

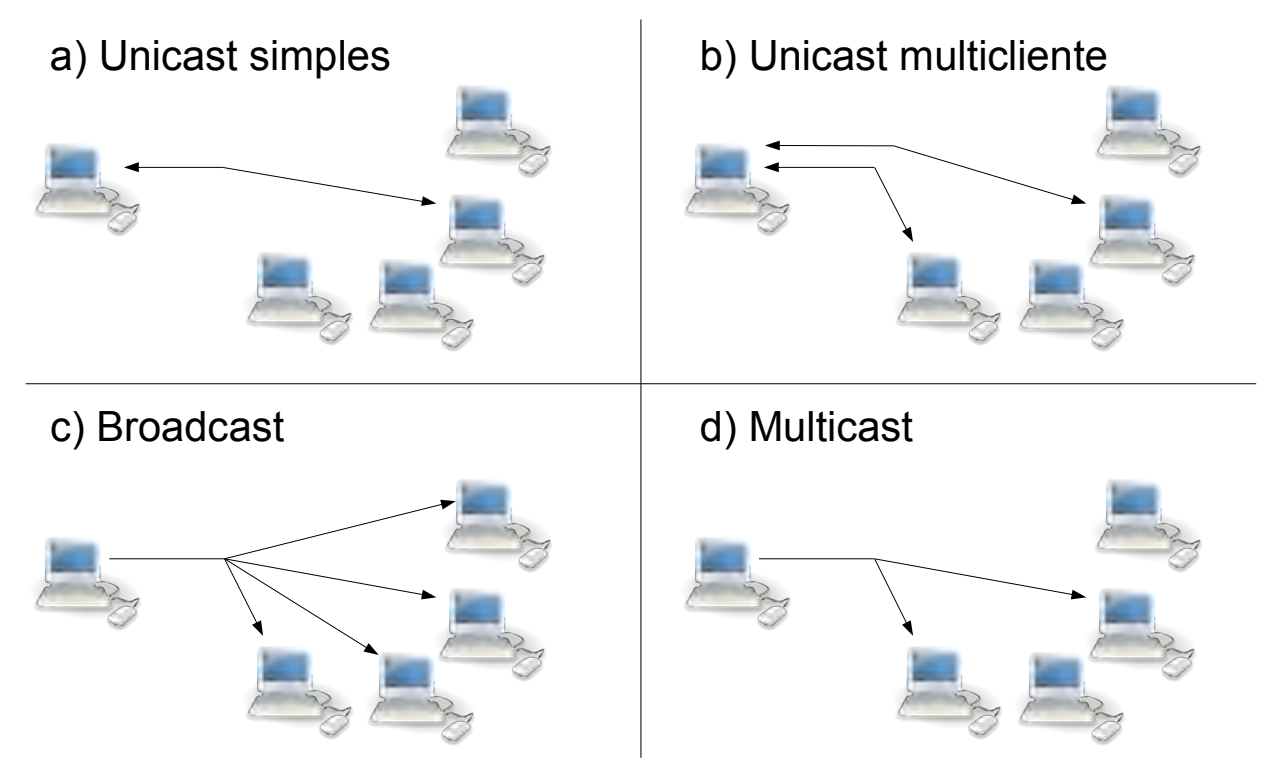

Figura 2.11: Modos de Endereçamento de Rede

\section{Unicast com Múltiplos Clientes}

Na comunicação Unicast simples o servidor não suporta múltiplos clientes. Todavia, é possível implementar um servidor Unicast que aceite vários clientes. Este método é a implementação mais comum de vários serviços de Internet como HTTP, FTP ou SSH.

Dependendo da implementação, o servidor pode enviar e receber dados distintos para cada cliente, como apresentado na Figura 2.11 (b), tratando cada cliente como uma conexão Unicast simples. O servidor pode ainda enviar a mesma informação a todos os clientes de sua lista. Neste caso, se um cliente for mais lento que os demais é possível que haja um gargalo da rede e a velocidade de transmissão aos demais clientes poderá ser comprometida de maneira indesejável. A solução empregada para que a velocidade de um cliente não interfira na entrega de dados para os demais é utilizar uma thread para tratar cada cliente. Esta solução traz em si a dessincronização do envio de dados.

\section{Broadcast}

Na engenharia elétrica e nas telecomunicações, o Broadcast é utilizado para a transmissão de dados para uma audiência dispersa, como em rádios ou TVs. O emissor envia dados por um 
determinado canal e vários receptores podem estar conectados neste canal para receber o dado transmitido. Por esta razão, o Broadcast é particularmente útil para a comunicação onde o emissor desconhece o endereço dos receptores.

No Broadcast em redes de computadores, o transmissor utiliza um endereço reservado da rede local (LAN), por exemplo 255.255.255.255 para redes IPV4, e o dado será recebido por todos os computadores da rede local que estão escutando a porta da transmissão [Mog84].

De maneira similar à transmissão televisiva, um emissor em uma rede local não sabe quantos receptores estão recebendo a mensagem transmitida ou mesmo se há algum receptor aguardando estas mensagens. Porém, diferentemente da comunicação de TV e rádio, onde os receptores envolvidos na comunicação não possuem condições de atuarem como emissores, em redes de computadores qualquer receptor pode se tornar emissor. Com isto vários emissores podem enviar dados ao mesmo tempo em uma transmissão Broadcast para a mesma porta em uma mesma rede.

É importante notar, como apresentado na Figura 2.11 (c), que todo computador na LAN irá receber a mensagem enviada para o Broadcast, mesmo se o mesmo não possui um receptor aguardando este dado. Neste caso, todo dado recebido será descartado localmente. Apesar da grande utilização do Broadcast em IPv4, o IPV6 não possui este modo de endereçamento. Nesta implementação do protocolo IP esta funcionalidade foi suplantada pelo endereço de Multicast [HD06].

\section{Multicast}

O Broadcast é um paradigma de comunicação extremamente poderoso e útil se a maior parte das máquinas de uma rede local estiver presente na comunicação. Caso a maior parte das máquinas estiver apenas descartando localmente os dados, este modo de endereçamento pode desnecessariamente sobrecarregar a rede. A solução neste caso é o endereçamento por Multicast.

Similar ao Brodcast, o Multicast é um conjunto de endereços de rede reservados. Diferentemente do Broadcast, o Multicast utiliza uma faixa de endereços IP de 224.0.0.0 até 239.255.255.255 em IPv4 [Ste94, CVM10].

Diferentemente de um Unicast com vários clientes, mas analogamente ao Broadcast, o Multicast é uma associação de um-para-muitos. Para receber as mensagens Multicast, um receptor deve se inscrever em um grupo Multicast. Como apresentado na Figura 2.11 (d), em uma comunicação Multicast uma única mensagem enviada é recebida por todos os clientes inscritos em um grupo. Um dispositivo de rede como um servidor, roteador, access point ou switch é responsável por gerenciar os grupos e inscrições. Este dispositivo pode ainda fornecer informações sobre a quantidade de máquinas que estão inscritas em um grupo.

O Multicast evita a retransmissão da mesma mensagem para cada cliente, como faz o Unicast com vários clientes, e evita a transmissão de mensagens para máquinas que não desejam receber dados, como faz o Broadcast. Por esta razão, o Multicast vem substituindo o Broadcast em serviços de descoberta em redes onde é necessário encontrar quais clientes existem em uma rede local [MSW08].

\section{Endereçamento na Internet}

A Internet surgiu inicialmente com a ideia de que cada dispositivo de rede deveria possuir um endereço IP único, porém o crescimento rápido da rede trouxe vários problemas como o esgotamento de endereços IPv4. Para conter este crescimento e a demanda por endereços IP, propôs-se uma solução onde várias máquinas utilizam um mesmo endereço IP [EF94]. Desta maneira, algumas faixas de endereços IP foram definidas para serem utilizadas apenas em redes privadas (LAN).

Os endereços reutilizáveis em LAN foram definidos em 3 classes: 192.168.0.0 a 192.168.255.255 (Classe C), 172.16.0.0 a 172.31.255.255 (Classe B) e 10.0.0.0 a 10.255.255.255 (Classe A) [RMK ${ }^{+}$96]. Todos os endereços IP destas faixas podem ser utilizados em várias redes locais devendo ser únicos apenas dentro de uma mesma rede; tais IPs são normalmente chamados de IPs inválidos pois os mesmo não são globalmente únicos e não podem ser utilizados para endereçar pacotes na Internet [EF94]. 
Para que as máquinas que utilizam tais endereços possam acessar a Internet, um mecanismo de roteamento foi proposto para traduzir os IPs internos para um endereço de Internet válido globalmente. Um dos mecanismos de tradução utilizado para esta tarefa é chamado NAT (Network Addess Translation) [SH99], sendo utilizado para definir a fronteira entre uma rede privada e a rede pública e tendo a função de permitir o acesso das máquinas da rede interna à rede externa de maneira transparente [DJCdMB11].

Um dispositivo de rede com a função de NAT possui 2 endereços IPs, um da rede interna que servirá de rota interna e outro da rede externa. Quando um pacote de uma máquina da rede interna acessa a rede externa, o NAT substitui o endereço local deste pacote pelo seu endereço de rede externa e envia o pacote para a rede externa. Este processo de substituição é chamado de tradução.

Para que a resposta a este pacote seja encaminhada da rede externa para a máquina correta da rede interna, o NAT mantém uma tabela com a tradução que contém o endereço privado, a porta privada e a porta pública [Sen02]. Desta maneira, quando o dispositivo recebe um pacote da rede externa ele consulta sua tabela de tradução e faz novamente a substituição do endereço do pacote, encaminhando-o com o endereço correto para a rede interna [SH99].

Com o NAT, um computador em uma LAN pode receber pacotes da rede externa apenas se ele mesmo iniciou a comunicação e possui uma seção de NAT associada a esta comunicação. Esta solução que efetivamente resolveu o problema da escassez do IPv4 criou várias dificuldades para a comunicação ponto a ponto entre máquinas de diferentes redes privadas [FSK05, HS01].

\section{Comunicação Ponto-a-ponto na Internet}

O NAT pode criar problemas para o endereçamento entre máquinas que utilizam conexões domésticas. Ao contrário de uma conexão com um navegador de páginas web, onde partimos da premissa que o servidor possui um IP globalmente válido e o cliente inicia a comunicação com este servidor, em uma comunicação ponto-a-ponto qualquer um dos nós poderia iniciar a comunicação, mesmo utilizando uma conexão doméstica com NAT. Exemplos de aplicações que utilizam este modelo incluem jogos para vários jogadores, voz sobre IP (VoIP), comunicações de multimídia, protocolos baseados em eventos (como mensagens instantâneas) e compartilhamento de arquivos [MRKS01, RWHM03].

Algumas técnicas podem ser aplicadas para permitir a comunicação P2P com ambos os nós conectados com NAT. Uma solução simples é utilizar um servidor de retransmissão que possua um IP global válido e não possua restrições de conexão como firewalls ou NAT. Esta solução pode garantir a conexão mas irá criar uma dependência em relação ao servidor para estabelecer a comunicação entre os pares. Por esta razão, esta solução irá aumentar a latência na comunicação e trazer problemas de desempenho [DJCdMB11].

Alguns dispositivos NAT podem ser configurados com uma tabela de roteamento estática [SE01]. Neste caso, um usuário com acesso privilegiado ao dispositivo pode configurá-lo de maneira que todo pacote recebido pelo IP público do NAT em uma faixa de valores de porta irá ser roteado para um endereço de IP interno utilizando a tabela estática [SH99]. Esta solução impede a reciclagem de portas e requer privilégios de configuração que não estão disponíveis em qualquer dispositivo de rede.

Outra solução que requer privilégios para a configuração do dispositivo é a Application Layer Gateways (ALGs) [RWHM03]. Este protocolo vem sendo embutido em dispositivos de rede e fornece para a camada de aplicação funções para atravessar o NAT [Sen02].

Outra técnica utilizada é definida pelo Simple Traversal of User datagram protocol (UDP) through Network (STUN) [SH99, RWHM03]. O STUN é uma arquitetura cliente-servidor que pode determinar o tipo do NAT e seu IP externo, e também descobrir a presença de firewalls entre a rede local e a Internet pública. O STUN é uma solução apenas para UDP e não funciona caso ambos os clientes estiverem sob o mesmo NAT [RWHM03]. A comunicação do STUN é baseada em uma técnica chamada UDP hole punching. 


\section{UDP Hole Punching}

Considere um computador A querendo se comunicar com um computador B, ambos atrás de um NAT e em redes locais diferentes; suponha que a aplicação P2P em ambos os computadores utiliza o protocolo UDP e a porta 12345 para a comunicação. Se A envia uma mensagem para o IP externo do NAT B, o NAT irá descartar esta mensagem pois não há uma seção esperando por uma mensagem na porta 12345. O mesmo ocorrerá se B iniciar a comunicação tentando acessar o NAT A. Porém, independentemente de B receber ou não a mensagem de A, o NAT A irá criar uma seção e fazer a tradução desta mensagem, o mesmo ocorrendo com o NAT B em relação à mensagem enviada a partir de B. A técnica de UDP hole punching utiliza esta seção criada no NAT quando um computador da rede interna envia uma mensagem para a rede externa [SFK08], utilizando um servidor para registro e descoberta de máquinas na rede.

Supondo o mesmo cenário anterior acrescido de um servidor de encontro S, ambos os computadores iniciam a comunicação enviando uma mensagem para S. Suas mensagens serão traduzidas pelos dispositivos NAT e irão conter o endereço do IP e porta público do NAT. Os dispositivos NAT irão assim criar seções aguardando por mensagens de resposta da rede pública. O servidor $\mathrm{S}$ então envia uma mensagem para A com o IP e porta público de B e uma mensagem para B com as informações de A. Uma vez que as seções foram criadas, os dispositivos NAT irão rotear qualquer pacote que chegar em seu IP e porta público para o computador correto em sua rede interna. Utilizando o endereço informado por $\mathrm{S}$ e as seções criadas em seus NAT, A e B podem agora iniciar uma conexão P2P típica.

\section{Considerações sobre UDP Hole Punching}

A técnica de Hole punching é a mais utilizada para garantir comunicação P2P em redes com NAT. De acordo com [FSK05], 82\% dos dispositivos de NAT testados suportam a utilização desta técnica.

Esta técnica é utilizada por várias aplicações comerciais como plataformas de jogos online e aplicações VoIP como o Skype. Infelizmente estas aplicações, quando proprietárias, não possuem especificações publicadas sobre seus protocolos para atravessarem o NAT [HS01].

Apesar do nome ser sugestivo, a técnica de hole punching não compromete a segurança da rede interna pois ela se baseia em uma solicitação de uma máquina da rede interna para iniciar a comunicação e consequentemente a seção no dispositivo NAT [FSK05]. De qualquer maneira, algumas técnicas de ataque previstas são listadas na definição do protocolo STUN [RWHM03].

Apesar do NAT ter surgido como uma solução para prolongar o tempo de vida do protocolo IPv4, a técnica de hole punching também é útil em redes que operam sobre o IPv6. Isto porque o NAT é a maneira mais simples de alcançar interoperabilidade entre redes IPv4 e IPv6. Mesmo no caso do IPv4 tornar-se totalmente obsoleto, esta técnica ainda pode ser útil para a comunicação entre computadores que encontram-se inacessíveis devido à presença de outros serviços de rede como firewalls e proxies.

\subsection{Desenvolvimento de Aplicações Musicais em Rede}

Ao considerarmos o desenvolvimento de aplicações de distribuição de conteúdo musical em tempo real por meio de redes de computadores, devemos considerar as especificidades tanto do desenvolvimento de aplicações musicais, como a escolha de APIs de áudio ou servidores de som, quanto do desenvolvimento de aplicações para redes, como a escolha de protocolos de transporte ou a decisão de fragmentar ou não o fluxo na camada de aplicação. Nesta Seção discutiremos alguns destes conceitos que muitas vezes se revelam características determinantes para o desenvolvimento e a utilização deste tipo de aplicação.

As características mais importantes em relação à rede para aplicações de áudio são a latência, a variação da latência (jitter) e a perda de pacotes na distribuição [BG96]. Além destas características, a largura de banda pode ser relevante na escolha de uma rede para determinada aplica- 
ção [KI98]. Por se tratarem de conceitos que podem possuir outros significados em outras áreas, iremos descrever como estes conceitos estão utilizados neste trabalho.

\section{Largura de Banda}

A largura de banda de uma rede representa a quantidade de dados por segundo que esta rede é capaz de transmitir. Há vários tipos de conexão utilizados em redes de computadores com diferentes larguras de banda.

O padrão doméstico mais difundido chama-se Ethernet e utiliza cabos de par trançado como meio de transmissão. O protocolo Ehternet possui especificações para tráfego a $1 \mathrm{Mbit} / \mathrm{s}, 3 \mathrm{Mbit} / \mathrm{s}$, $10 \mathrm{Mbit} / \mathrm{s}, 100 \mathrm{Mbit} / \mathrm{s}$ e $1 \mathrm{Gbit} / \mathrm{s}$ (Giga bit por segundo ou 1000Mbit/s). Já a conexão sem fio, que utiliza o ar como meio físico e possui vários padrões de transmissão como, por exemplo, o IEEE 802.11 que possui uma velocidade máxima de transmissão de $54 \mathrm{Mbit} / \mathrm{s}$ e o $802.11 \mathrm{n}$ que possui uma velocidade de transmissão de $300 \mathrm{Mbit} / \mathrm{s}$. A conexão Ethernet que utiliza fibra ótica como meio físico de transmissão também possui diferentes velocidades de transmissão, como 10Gbit/s, 40Gbit/s e 100Gbit/s.

Dados de áudio com taxa de amostragem de $48 \mathrm{kHz}$ e resolução de 32 bits por amostra correspondem a uma quantidade aproximada de $1.54 \mathrm{Mbit} / \mathrm{s}$. A quantidade aproximada de canais de áudio, com esta resolução e taxa de amostragem, que pode ser transmitida em cada meio físico é apresentada na Tabela 2.2.

Tabela 2.2: Relação entre Largura de Banda e Capacidade de Transmissão

\begin{tabular}{lcc}
\hline Camada física & Capacidade de transmissão & Quantidade de canais \\
\hline Par trançado & $10 \mathrm{Mbit} / \mathrm{s}$ & 6 \\
Par trançado & $100 \mathrm{Mbit} / \mathrm{s}$ & 64 \\
Par trançado & $1 \mathrm{Gbit} / \mathrm{s}$ & 649 \\
Wireless & $54 \mathrm{MBit} / \mathrm{s}$ & 35 \\
Wireless & $300 \mathrm{Mbit} / \mathrm{s}$ & 194 \\
Fibra ótica & $10 \mathrm{Gbit} / \mathrm{s}$ & 6493 \\
Fibra ótica & $100 \mathrm{GBit} / \mathrm{s}$ & 64935 \\
\hline
\end{tabular}

Esta quantidade de canais que cada meio de transmissão permite na teoria pode não ser atingível pois na prática isto vai depender do overhead causado pelo empacotamento dos canais de áudio para a transmissão na rede e também da quantidade de pacotes de controle que podem ser necessários para, por exemplo, confirmar o recebimento ou retransmitir um pacote perdido ou danificado.

Vale ainda lembrar que o áudio é transmitido junto com outros dados da rede, como páginas de Internet, atualizações do sistema operacional e qualquer outro acesso à rede que o usuário ou seu sistema podem vir a fazer.

\subsubsection{Latência}

O tempo de espera de um sistema para que a resposta, reação ou resultado seja recebido após um estímulo gerador é chamado latência. A latência em processamento sonoro é tão importante que muitas vezes a baixa latência é adotada como critério para a denominação de sistemas de processamento sonoro em tempo real [LK04].

Em sistemas sonoros, latência é sinônimo do atraso em um sinal sonoro, que muitas vezes é inerente à propagação sonora em um meio físico. Assim, podemos afirmar que existe uma latência imposta pela própria velocidade do som: como o som no ar em condições normais (ar seco a $20^{\circ}$ e pressão normal) possui uma velocidade de propagação aproximada de $343 \mathrm{~m} / \mathrm{s}$, isto implica que naturalmente existe uma latência de $2.92 \mathrm{~ms}$ por metro na propagação sonora; em particular dois músicos que estejam a três metros de distância um do outro (uma situação comum em um palco) perceberão uma latência de quase $9 \mathrm{~ms}$ no som produzido pelo outro. Ao aumentarmos esta 
distância, aumentamos a latência, que pode chegar a níveis que impedem a execução sincronizada de uma peça por dois músicos [LW01].

Os valores proibitivos de latência variam de acordo com o tipo de música a ser executada e também do nível de tolerância entre os músicos. Experimentos sugerem diferentes valores para o limite de latência em sistemas sonoros, como $11.6 \mathrm{~ms}$ [CGLT04], $30 \mathrm{~ms}$ [LK04] ou mesmo valores superiores [SS06].

Em sistemas computacionais que utilizam rede para transmissão musical, a latência na transmissão envolve o atraso na placa de som e o atraso na rede [CKS06]. A causa mais direta de latência na música em rede são os buffers presentes entre a captura do som, a transmissão pela rede e a reprodução em outra máquina. Neste processo existem tanto buffers de áudio quanto buffers de rede. Os buffers de áudio são inerentes ao processamento enjanelado de um sinal digital e podem ocorrer em várias camadas da arquitetura de áudio de um sistema. Por exemplo, ao executarmos um aplicativo sobre o servidor de som JACK, rodando sobre o PortAudio, por sua vez rodando sobre o ALSA, em todas estas camadas encontraremos buffers de áudio independentes.

Além da existência de buffers, o atraso na placa de som envolve também a conversão A/D e $\mathrm{D} / \mathrm{A}$, o processamento de dados no computador, o atraso do driver do dispositivo e mesmo o tipo de conexão que a placa utiliza com o computador, como PCI, Firewire ou USB. Por esta razão, é bastante difícil precisar de uma maneira genérica o atraso total causado pela placa de som, embora ele seja normalmente inferior ao atraso dos buffers. Em sistemas específicos, a latência na interface de áudio pode ser medida conectando a entrada da placa em sua saída, gerando assim um loopback, que pode ser interceptado por algum medidor de atraso [LW01, $\left.\mathrm{CWL}^{+} 00\right]$.

Já o atraso da rede pode ser associado ao buffer de rede, ao tipo de conexão utilizado, ao protocolo utilizado, a distância entre os pontos e também à quantidade de nós intermediários que existem entre dois pontos remotamente conectados, como ilustrado pela Figura 2.12.

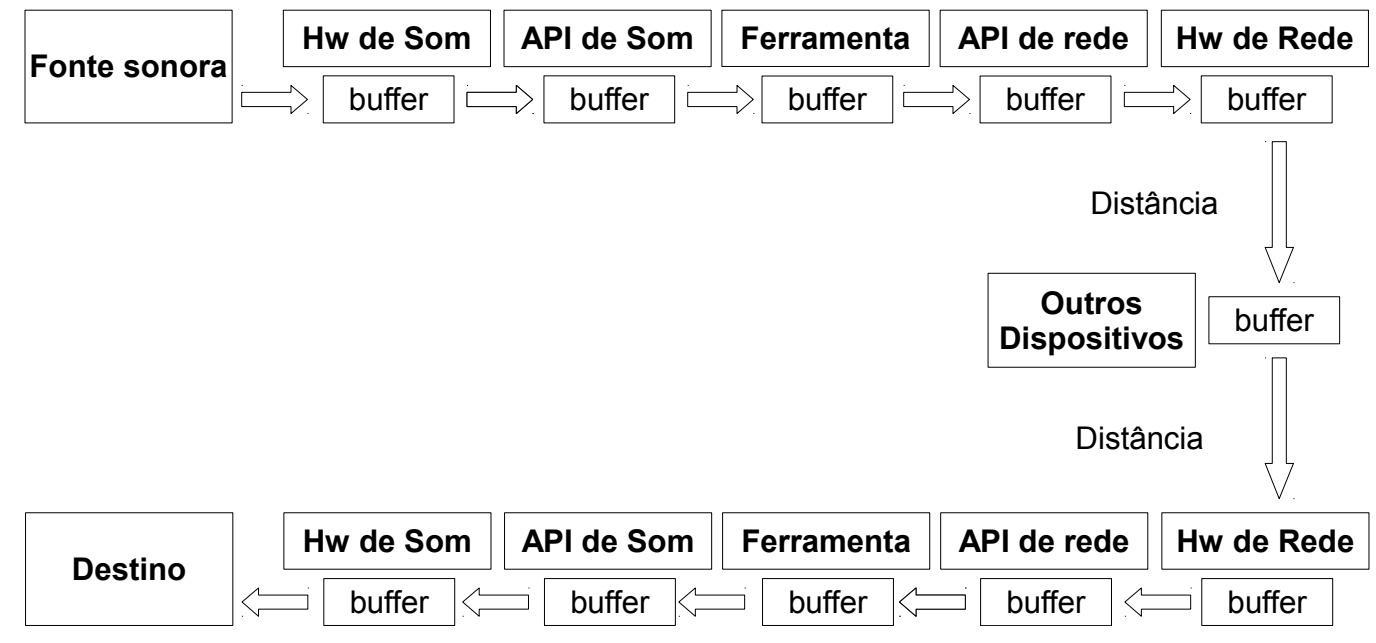

Figura 2.12: Latência de Música em Rede

Os buffers de rede são partes quase obrigatórias no processo de transmissão de dados pela rede. O envio de dados depende do empacotamento deste dados em pequenas unidades a serem transmitidas. Os buffers de áudio são muitas vezes configuráveis em todas as camadas e aplicações, enquanto os buffers de rede são normalmente ocultados pela implementação do sistema operacional, e nem sempre acessíveis a configurações por usuários comuns.

A limitação física e a configuração de buffer para envio / recebimento de dados não depende apenas dos computadores que estão recebendo ou enviando dados, mas de todos os dispositivos de rede que encontram-se no caminho entre estes computadores. Os nós intermediários podem possuir configurações diferentes e nem sempre (ou quase nunca) é possível alterar a configuração destes dispositivos. Assim, se dois computadores que possuem interfaces de rede de $1 \mathrm{Gbit} / \mathrm{s}$ estão conectados por meio de um roteador, hub, switch ou qualquer outro dispositivo de rede com capacidade menor, os dados serão transmitidos respeitando a capacidade deste último dispositivo, e subutilizando os 
equipamentos transmissor / receptor.

Por último, a latência relacionada ao protocolo de transmissão depende também do buffer usado por este protocolo, mas está associada, neste caso, ao mecanismo de ordenação dos dados recebidos e de verificação de integridade.

\subsubsection{Jitter}

Em uma conexão de redes, a latência na transmissão de dados quase sempre não é uniforme e pode variar ao longo da transmissão; a esta variação da latência dá-se o nome de jitter [SFW10]. O jitter pode ser causado por diversos fatores como o comportamento da conexão física, o aumento da utilização da rede e a perda e o reenvio de muitos pacotes.

Além da velocidade de transmissão de um meio físico, os padrões de conexão também definem o comportamento e a estabilidade da transmissão. Em uma conexão sem fio, por exemplo, o meio físico é compartilhado e todos os participantes da conexão devem esperar a disponibilidade do meio para transmitir dados. Isto implica que não há garantia nenhuma de latência máxima para esta conexão.

O aumento na utilização de uma rede pode fazer com que a quantidade de dados trafegados seja maior do que a capacidade do meio. Os buffers de rede serão então utilizados para armazenar dados temporariamente de forma a tentar garantir que todos os dados sejam transmitidos, sem contudo garantir agilidade na transmissão. Vale lembrar que nem sempre conseguimos controlar a utilização da rede, pois há vários processos em um computador que podem requisitar o uso da rede, sendo isto transparente ao usuário.

Em redes TCP/IP, a perda e reenvio de pacotes estão associados à confiabilidade do protocolo de transporte. Todos os protocolos de transporte trabalham sobre o protocolo IP, que não possui garantia de entrega. Por esta razão, um protocolo de transporte confiável tem que garantir o recebimento dos dados, por meio de mensagens de confirmação que são enviadas a cada pacote de rede recebido, e do reenvio de pacotes sem confirmação de recebimento, o que introduz variabilidade na taxa de recebimento de pacotes. Além disto, como os protocolos de transporte confiáveis garantem o recebimento ordenado, no caso de atraso em um pacote todos os demais pacotes de um mesmo fluxo serão retidos, aumentando o atraso e o jitter.

Ainda em relação ao comportamento de protocolos de transporte, pode existir alguma forma de controle de congestionamento, correspondendo a um ajuste na velocidade de transmissão em relação à capacidade do canal de transmissão, para evitar a sobrecarga do canal. Por exemplo, o comportamento padrão do protocolo TCP é ter um início de transmissão lento (slow start) com um aumento gradual da quantidade de dados transmitidos até que um nível máximo seja alcançado sem sobrecarregar a rede. Mesmo depois de alcançado este nível máximo, o protocolo irá sempre medir a capacidade do canal e variar a quantidade de dados tentando enviar o máximo de dados possível. Apesar de existirem diferentes implementações deste comportamento, o mesmo é uma característica do TCP que não pode ser desabilitada pelo usuário. Isto implica que este protocolo sempre terá jitter e que a aplicação deve manter um buffer próprio caso queira evitar este jitter.

\subsubsection{Perda de Pacotes}

Em uma transmissão de dados em redes de computadores pode ocorrer a perda de pacotes de dados por diversas razões, como a interferência no sinal pelo meio físico, o estouro de buffers em roteadores, switches e outros periféricos de rede, o congestionamento de dados, a falha na verificação de integridade de um pacote, falhas físicas nos dispositivos envolvidos na transmissão, entre outras razões.

Outra causa de perda de pacotes é o congestionamento de dispositivos de rede que estejam no caminho entre os dois nós que estão em comunicação. Caso um dispositivo de rede, como um switch, HUB ou roteador, receba mais dados que consegue armazenar em seu buffer, estes dados serão descartados. Para evitar que isto aconteça, alguns protocolos verificam primeiramente a capacidade de transmissão do canal, para só depois começar a enviar dados para a rede. 
A quantidade de dispositivos no caminho de um pacote pode também fazer com que o mesmo seja descartado, devido ao seu TTL; caso este valor seja alcançado, o pacote será descartado pelo dispositivo em seu caminho.

Por fim, todo pacote em rede TCP/IP possui um campo para verificação de integridade de dados chamado checksum; um pacote que possua erro de checksum é considerado por muitos protocolos como um pacote perdido. A não confirmação de integridade de dados é tratada como não recebimento do pacote e o mesmo é geralmente descartado.

As técnicas utilizadas pelos protocolos confiáveis, como TCP ou SCTP, para a garantia de entrega podem não ser adequadas para o cenário específico de música em rede. A transmissão assíncrona de dados, onde o envio de dados pode ocorrer em um tempo diferente de sua produção, consegue tirar vantagens destes mecanismos confiáveis. Já na transmissão síncrona, onde o dado é enviado no momento onde ele é criado, esta garantia de entrega pode não ser uma vantagem, já que um pacote perdido e reenviado pode não alcançar o destino em tempo hábil para a sua utilização.

\subsection{Metodologia}

A metodologia utilizada para o desenvolvimento deste trabalho iniciou-se com a pesquisa dos conceitos envolvidos apresentados neste Capítulo e a interação direta com músicos interessados em ferramentas de música em rede, e foi completada com a pesquisa de ferramentas relacionadas apresentada na Seção 1.2. A interação com músicos permitiu parcerias com compositores [OS11a] [OS11b] [OFS13] em criações baseadas em redes e auxiliou a entender os desafios de realizar concertos telemáticos no Brasil [ATIQ13]. Estudar tais conceitos e ferramentas permitiu mapear uma lista de requisitos importantes que uma ferramenta deve ter para satisfazer diversos cenários de aplicação, e que podem ser entendidos como etapas (ainda que não linearmente ordenadas) numa metodologia de desenvolvimento. Esta metodologia é apresentada na Figura 2.13.

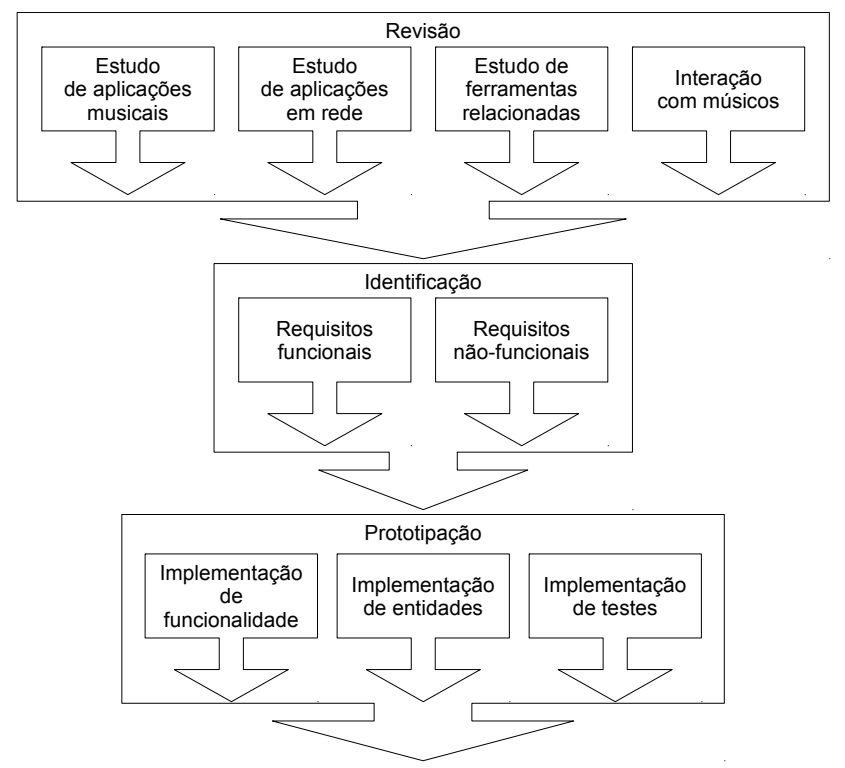

Figura 2.13: Metodologia do Trabalho

Os requisitos funcionais são funcionalidades específicas que o sistema deve ter, como o envio de áudio e MIDI ou o envio de mensagens de Chat. Já os requisitos não funcionais dizem respeito às características de usabilidade, desempenho e manutenção, por exemplo, como a recuperação de falhas de rede ou a implementação de interfaces para o usuário.

$\mathrm{Na}$ prototipação, o desenvolvimento dos requisitos mapeados foi iniciado pela escolha da camada da arquitetura responsável por atender a cada requisito. Definida a camada, verificou-se se uma entidade já definida poderia integrar a nova funcionalidade, ou se havia a necessidade de implementar uma nova entidade. Uma vez definido tal passo, o requisito foi adicionado a um protótipo 
do sistema e testado.

Apresentaremos a seguir alguns requisitos mapeados, protótipos desenvolvidos e as experiências adquiridas com o desenvolvimento dos mesmos.

\subsubsection{Levantamento de Requisitos}

\section{Reconfiguração do Áudio Para o Envio Pela Rede}

A diminuição da quantidade de dados a serem trafegado em uma comunicação de áudio em rede é verificada em algumas ferramentas relacionadas, sendo que diferentes técnicas foram empregadas neste sentido.

Uma primeira técnica é a utilização de CODECs de compressão. Apesar de bastante explorada, esta técnica pode não ser ideal para qualquer cenário pois aumenta a necessidade de processamento para o envio e recebimento de áudio.

Outra técnica utilizada é a mixagem de vários canais no envio. Apesar de diminuir consideravelmente a quantidade de dados trafegados e possibilitar a parametrização desta quantidade, outra vez isto pode não ser ideal para todos cenários, porque uma vez mixados, o conteúdo dos canais originais separados não pode mais ser recuperado.

Outra possibilidade é a diminuição no formato de amostras. Apesar da maior parte das ferramentas representar amostras por um tipo float de 32 bits, a reamostragem em inteiros de 24,16 ou 8 bits diminui consideravelmente o volume de dados trafegados, ao custo de introduzir ruído de quantização.

Além destas possibilidades, acrescentamos aqui também a possibilidade de mudança na taxa de amostragem, o que permitiria uma escolha paramétrica da quantidade de dados trafegados, ao custo de limitar a faixa de frequências representáveis, além de introduzir distorções no sinal (por rebatimento ou filtragem passa-baixas).

\section{Apresentação Gráfica}

Uma característica mapeada através de experimentos com potenciais usuários (músicos voluntários), em testes com as ferramentas relacionadas, diz respeito à apresentação gráfica de estado da rede e mensagens.

Ferramentas que podem ser configuradas graficamente possuem maior aceitação por parte de usuários não-programadores que ferramentas que operam em modo texto. Mesmo ferramentas que operam em modo gráfico apresentaram poucas possibilidades de interação e baixa representação do estado da comunicação em rede.

Entre as necessidades mapeadas na apresentação gráfica estão, por exemplo, o monitoramento da latência da comunicação. Monitorar a latência pode fornecer subsídios para que o usuário de uma ferramenta possa ajustá-la de maneira mais precisa segundo suas necessidades. A utilização de pacotes extras para a medição desta latência pode causar um maior uso da rede e, portanto, trazer um custo maior à comunicação. Por esta razão, tal característica pode ser disponibilizada de maneira interativa, permitindo ao usuário medir a latência e o estado da rede apenas quando achar necessário.

Outra apresentação gráfica que pode ajudar o usuário a verificar o estado atual da comunicação é a apresentação das amplitudes dos sinais de entrada e saída do sistema. Medidores de amplitude podem mostrar ao usuário o nível do sinal sonoro trafegado e ajudá-lo a identificar visualmente um possível problema de comunicação.

\section{Envio de Diferentes Tipos de Informação}

Em uma atividade musical distribuída é frequentemente necessário transmitir diferentes tipos de dados em uma rede, como sinais de áudio, comandos simbólicos, vídeo, etc. O tráfego exclusivo de conteúdo musical pode não atender a todos os requisitos necessários para garantir uma atividade musical em rede, e outros tipos de mensagens podem ajudar nesta tarefa. 
Mensagens de controle podem ser utilizadas para acessar remotamente uma máquina para, por exemplo, reconfigurar suas conexões de áudio durante a preparação de uma apresentação musical. Exemplos destas mensagens de controle seriam o controle remoto do mecanismo de Transport do $\mathrm{JACK}^{2}$ ou ligar / desligar remotamente o DSP no ambiente Pure Data ${ }^{3}$. Tais mensagens podem garantir a sincronização de processos oferecendo a possibilidade de controle e configuração remotos.

Mensagens de texto podem ser utilizadas para vários propósitos, incluindo a reconfiguração de máquinas e sincronização de músicos em uma apresentação. As mensagens de texto não têm por objetivo sincronizar processos mas permitir a comunicação entre pessoas.

Mensagens de configuração podem ser utilizadas para informar a configuração de áudio ou rede e simplificar a configuração e conexão entre duas máquinas na rede.

A necessidade de combinar a transmissão de fluxos de Áudio e MIDI também foi presenciada ao trabalhar com músicos voluntários, porque eles frequentemente combinam conexões de áudio entre instrumentos, microfones e equipamentos de hardware, com a utilização de controladores e instrumentos MIDI.

\section{Integração de Software Legado}

A necessidade de integrar a ferramenta com software legado [You01] é decorrente do fato de que todo usuário está acostumado a trabalhar com uma aplicação específica para processamento de som, e idealmente espera poder transmitir áudio para a rede a partir desta ferramenta.

A pesquisa apresentada neste Capítulo mapeou várias APIs de desenvolvimento de software para processamento de áudio e MIDI, permitindo tratar o sistema de áudio do computador como um sistema em camadas. Esta visão em camadas das APIs de som cria a possibilidade de integrar uma ferramenta de rede com o sistema operacional, com um servidor de som, ou com outros aplicativos na forma de plugins de áudio / MIDI.

\section{Processamento de Áudio}

Outra característica desejável é a capacidade de processamento de áudio. Este processamento pode ajudar a resolver problemas como a limitação de latência, largura de banda e heterogeneidade. O processamento também pode permitir que nós com configurações distintas possam se comunicar de maneira transparente ficando a ferramenta responsável pelos ajustes necessários resultantes da heterogeneidade dos nós.

As heterogeneidades do sinal de áudio já foram apresentadas na Seção 2.1.1 deste trabalho e dizem respeito às diferentes possibilidades de representação do áudio. Assim, podemos dizer que os processamentos serão utilizados para converter o áudio para o formato comum da rede, ajustar tamanhos de buffers, formatos de amostra e quantidade de canais. Este processamento também pode ser utilizado para correção de pacotes e tratamento de erros [CWL $\left.{ }^{+} 00\right]$.

Outros benefícios que o processamento de áudio pode trazer para a ferramenta incluem funcionalidades como o controle de volumes em canais enviados / recebidos, a limitação e compressão do sinal recebido para evitar limites indevidos de ganho, a compactação de dados $\left[\mathrm{CWL}^{+} 00\right]$ para o envio e também a utilização de detecção de silêncio [BG96] para evitar que a rede seja utilizada quando não há sinal a ser transmitido. Vale a pena lembrar que a utilização de algoritmos de detecção de silêncio adiciona um elemento não determinístico na utilização da largura de banda, devendo seu uso ser facultativo segundo a escolha do usuário.

\section{Sincronização de Dispositivos e Buffers de Áudio}

Ao conectarmos um dispositivo de som a um dispositivo de rede temos um problema de sincronizar dois dispositivos de $\mathrm{E} / \mathrm{S}$ que não possuem necessariamente a mesma velocidade. $\mathrm{O}$ dispositivo

\footnotetext{
${ }^{2}$ Mensagem de sincronização (Play / Stop) enviadas a todas as ferramentas conectadas ao servidor JACK, que permitem iniciar ou parar de maneira síncrona gravadores e sequenciadores que utilizam este servidor de som.

${ }^{3} \mathrm{O}$ PD depende deste comando para iniciar ou interromper o processamento de áudio
} 
de som é sincronizado por uma taxa de amostragem que depende da configuração local do dispositivo. A API de rede não possui a mesma noção de tempo ou compromisso com o tempo de entrega de um pacote. Por esta razão, mesmo protocolos que garantem a entrega de um pacote podem não ser capaz de fazê-lo no prazo de tempo esperado pela API de som. A visão deste problema de sincronização é a de processos produtores / consumidores, onde no envio a API de som gera conteúdo que será consumido pela API de rede, e no recebimento, tal processo se inverte e temos a API de rede gerando conteúdo para ser consumido pela API de som.

A solução encontrada em trabalhos relacionados para a sincronização entre o processo produtor e o processo consumidor é a utilização de buffers circulares no envio e recebimento. No recebimento, a presença de tais buffers pode também ajudar a solucionar a ordenação de pacotes e a correção no caso de perdas de pacotes, funcionando ao mesmo tempo como mecanismo de sincronização e de controle de fluxo.

\section{Disponibilidade}

A alta disponibilidade de recursos é também uma característica notada em sistemas distribuídos. Garantir alta disponibilidade significa muitas vezes replicar um recurso de forma a torná-lo disponível em mais de um endereço. A replicação de recursos em tempo real aumenta sua disponibilidade mas adiciona latência ao sistema. Por esta razão, tal solução é adotada por poucas ferramentas de transmissão de áudio em rede, como o Ninjam e o llcon. Por outro lado, adicionar um servidor de replicação pode simplificar a conexão de usuários domésticos que se encontram geograficamente distribuídos.

\subsubsection{Prototipação}

Tal pesquisa foi feita juntamente com o desenvolvimento de protótipos que atendiam parte dos requisitos aqui apresentados.

O primeiro protótipo da Medusa foi feito em $\mathrm{C}++$ de forma monolítica e baseado no servidor de som JACK e em Qt. Este protótipo contava com mensagens de controle para a transparência de localização e publicação de recursos.

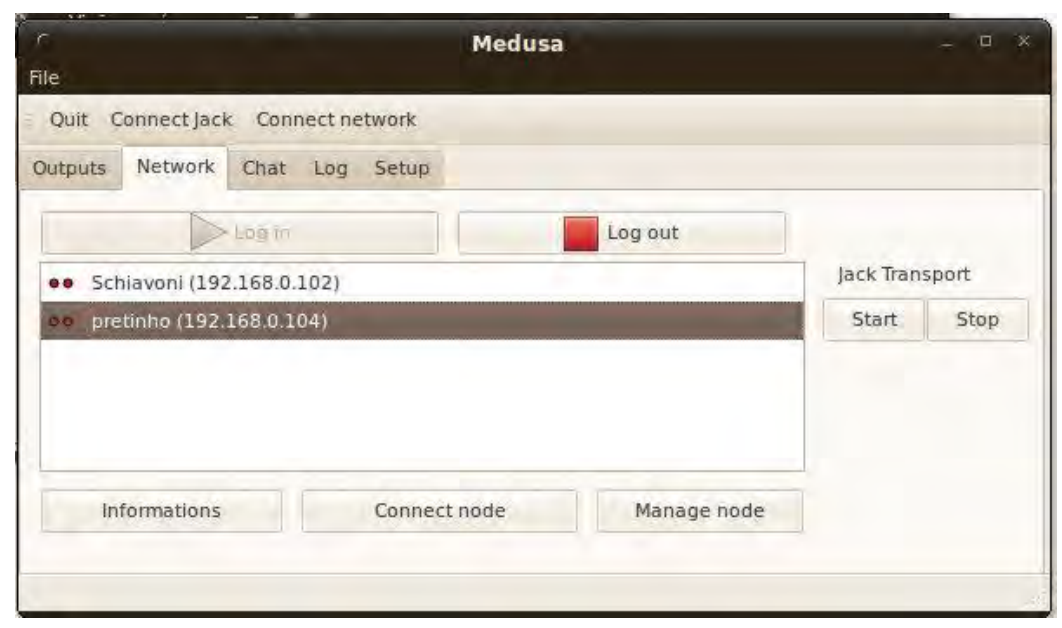

Figura 2.14: Primeiro Protótipo da Medusa

Ampliando a pesquisa sobre protocolos de rede, este protótipo possuía apenas algumas mensagens de controle e utilizava diferentes protocolos para o envio de diferentes dados. Foi utilizado o protocolo UDP e o endereçamento Broadcast para mensagens de controle públicas e o protocolo TCP para envio de mensagens de controle privadas. Além disto, foi utilizado o protocolo SCTP para o envio e recebimento do conteúdo musical.

As escolhas de API desde o primeiro protótipo buscavam a interoperabilidade do código e possibilidades de compilação em diversas plataformas como Linux, Mac e Windows, onde existem 
versões disponíveis do servidor de som JACK.

O segundo protótipo da Medusa, ainda em $\mathrm{C}++$, ampliou a visão do usuário e trouxe a visão do ambiente de maneira gráfica.

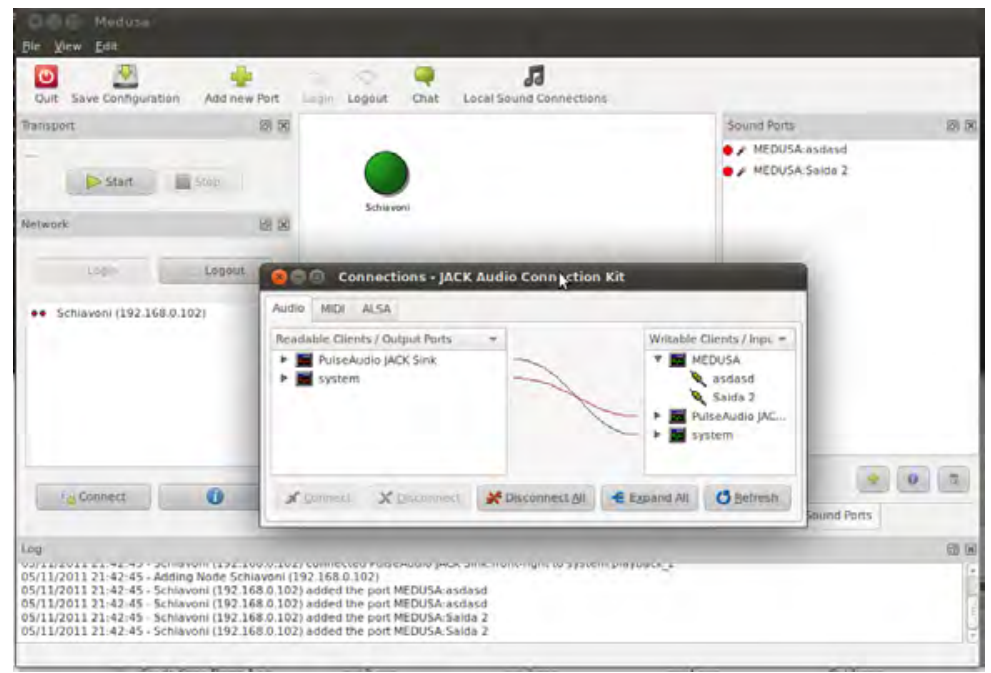

Figura 2.15: Segundo Protótipo da Medusa

Este protótipo, ainda monolítico, também utilizava o protocolo de transporte SCTP para envio de sinais de áudio e MIDI, contava ainda com o JACK como API de áudio e acrescentou mensagens MIDI ao ambiente.

O terceiro protótipo da Medusa ampliou as possibilidades de protocolos de transporte adicionando à ferramenta a capacidade de trabalhar com os protocolos UDP, TCP, DCCP e SCTP para o envio de áudio e MIDI.

Apesar da escolha inicial da API de som utilizar o servidor JACK, e do fato deste servidor ser utilizado por inúmeras aplicações de áudio, esta escolha não refletia a necessidade de integração com software legado. Por esta razão, a possibilidade de levar uma ferramenta de áudio em rede para dentro de outras ferramentas musicais motivou o desenvolvimento da Medusa com outras APIs de áudio.

Analisando os primeiros protótipos da ferramenta concluímos que, devido ao alto acoplamento do código, a implementação monolítica impediria a reutilização do código da ferramenta em implementações que utilizassem outras APIs. Esta análise levou a uma importante mudança arquitetural da ferramenta visando a diminuição do acoplamento do código entre as camadas da arquitetura. A visão desta arquitetura será apresentada no próximo Capítulo. 


\section{Capítulo 3}

\section{Arquitetura proposta}

A definição de uma arquitetura de sistema para o desenvolvimento de um software é um passo importante, pois a arquitetura ajuda a definir a maneira como os componentes do software serão implementados e irão se comunicar ou interagir, e ao mesmo tempo abstrai detalhes de implementação. Além disto, podemos fazer uma divisão de responsabilidades, atribuindo a cada componente a tarefa de resolver uma característica mapeada através das funcionalidades especificadas.

O modelo arquitetural encontrado em protocolos de comunicação, como o modelo de referência ISO da OSI e o modelo de referência da pilha de protocolos TCP/IP, é o modelo em camadas. Neste modelo arquitetural, ao definirmos as camadas do sistema e os componentes de cada camada definimos também a interface de comunicação entre estes componentes, planejando a troca de mensagens entre eles e definindo os tipos de dados necessários para a implementação.

A utilização de uma arquitetura em camadas permite delimitar as funcionalidades do sistema reforçando as responsabilidades e guiando o desenvolvimento. Além de facilitar a implementação da ferramenta, tal arquitetura também facilita a manutenção e a expansão da ferramenta. A manutenção é facilitada pois uma alteração em uma camada reflete apenas em suas camadas adjacentes.

A interface de cada componente será representada aqui utilizando um diagrama de caso de uso para as entidades previstas na arquitetura. Este diagrama faz parte do conjunto de diagramas da UML (Unified Modeling Language) e corresponde a uma representação em alto nível das funcionalidades previstas em um sistema.

A arquitetura proposta neste trabalho, apresentada na Figura 3.1, é bastante semelhante à arquitetura básica apresentada na Figura 1.1 e também assemelha-se às arquiteturas de várias ferramentas relacionadas.

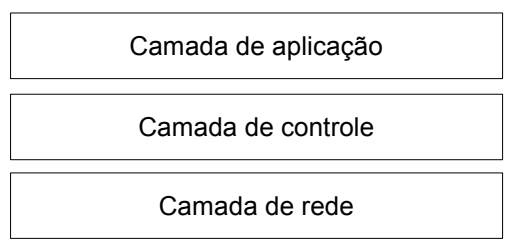

Figura 3.1: Visão da Arquitetura da Ferramenta.

Nesta arquitetura tratamos a captação dos fluxos de conteúdo musical pela camada de aplicação, a sincronização local dos fluxos na camada de controle e a conexão de rede para o envio / recebimento pela camada de rede. A camada de aplicação proposta inclui a interface com o usuário, por meio de GUIs ou TUIs.

A arquitetura apresentada deverá estar presente em cada instância da rede, também chamada nó. A junção de todos os nós será chamada de ambiente. As mensagens trocadas no ambiente são chamadas de públicas, quando endereçadas a todos os nós do ambiente, e privadas, quando esta comunicação ocorre apenas entre os nós interessados em receber esta mensagem.

A seguir faremos a apresentação de cada camada partindo da camada de rede. 


\subsection{Camada de Rede}

Em redes de computadores, a comunicação é sempre iniciada por uma das partes, denominada cliente, enquanto a outra parte, denominada servidor, é responsável por responder a esta comunicação. Um servidor aguarda a conexão de clientes e por isto não precisa conhecer o endereço dos clientes; já o cliente, responsável por iniciar a conexão, tem a responsabilidade de conhecer o endereço do servidor. Juntos, cliente e servidor criam uma aplicação distribuída [DC09, p. 7].

Indo além da sequência de passos e das informações necessárias para a criação de uma conexão, há outra diferença entre os papéis de cliente e servidor. Em se tratando de conexões Unicast, que é o modo de endereçamento suportado por todos os protocolos de transporte, um cliente se conecta apenas a um servidor, enquanto um servidor pode possuir vários clientes conectados.

Apesar desta terminologia, estes papéis estão associados especificamente com o início da comunicação. Uma vez estabelecida uma conexão, esta relação entre os nós é substituída por um protocolo de aplicação que irá definir o fluxo de dados e que recursos serão compartilhados por meio da rede.

$\mathrm{Na}$ arquitetura aqui proposta, a camada responsável por criar e gerenciar conexões de rede é chamada Camada de rede. Esta camada possui dois componentes, chamados Cliente Medusa e Servidor Medusa, ilustrados na Figura 3.2.

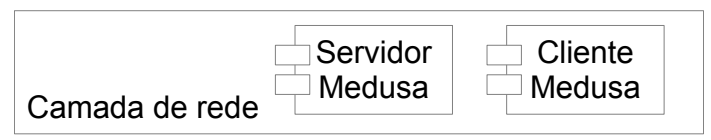

Figura 3.2: Diagrama de Componentes da Camada de Rede

Um Servidor Medusa é um servidor TCP/IP que pode atender vários clientes, aguardando suas conexões. Um Cliente Medusa é um cliente que se conecta em apenas um Servidor Medusa, definido por um endereço conhecido de antemão. Os conceitos de cliente e servidor no endereçamento Unicast foram estendidos para os endereçamentos Multicast e Broadcast. Neste caso, o cliente precisa conhecer não o endereço do servidor mas o endereço Multicast / Broadcast onde o Servidor está publicando seus dados. Independentemente desta diferença técnica, manteremos o conceito de cliente e servidor mesmo quando tratarmos destes endereçamentos.

Como no modelo TCP/IP, tanto cliente quanto servidor podem enviar e receber dados pela rede deixando a definição de fluxo de dados para as camadas superiores desta arquitetura.

A seguir, apresentaremos estes componentes com mais detalhes.

\section{Servidor Medusa}

O Servidor Medusa é o componente que aguarda a conexão de um ou mais clientes para iniciar o envio e recebimento de dados, solicitados e repassados a uma aplicação. A configuração de um Servidor é feita através da especificação de um protocolo e/ou modo de endereçamento e da porta de rede. O servidor deverá manter uma lista de clientes conectados e comunicar para a aplicação a conexão e desconexão de clientes. As obrigações do servidor são explicitadas no diagrama de caso de uso da Figura 3.3.

O tempo de envio de pacotes deve ser monitorado para que seja possível eliminar localmente pacotes cujo tempo de envio ultrapassar um limite desejado e evitar o congestionamento da rede. Caso o Servidor elimine pacotes no envio a aplicação deverá ser comunicada.

\section{Cliente Medusa}

O Cliente Medusa é o componente que se conecta a um servidor para o envio e recebimento de dados. Por esta razão, para a configuração de um Cliente deverá ser informado o protocolo e/ou endereçamento do Servidor, além de seu endereço IP e porta. Ao contrário do servidor, o Cliente não precisa conhecer seu próprio endereço, e deve utilizar a configuração do servidor para iniciar a conexão. A Figura 3.4 apresenta os casos de uso que um Medusa Cliente deve possuir. 


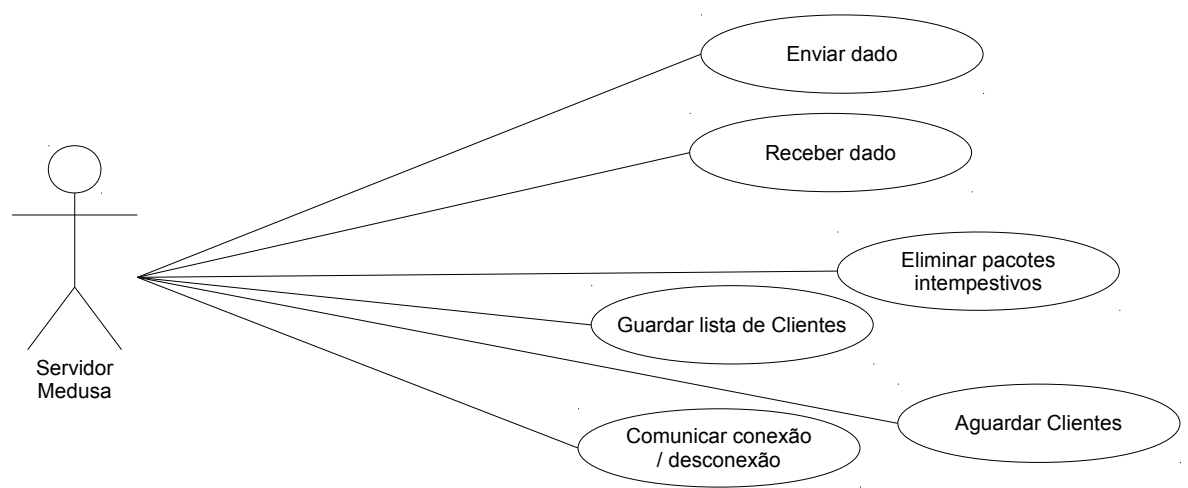

Figura 3.3: Diagrama de Caso de Uso do Servidor Medusa

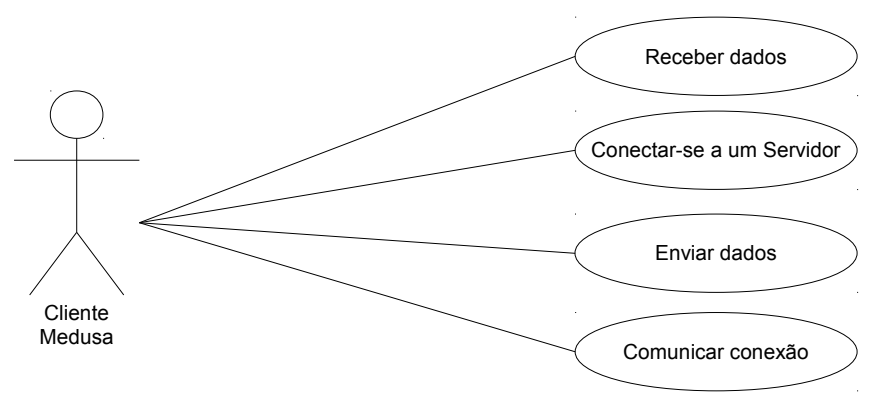

Figura 3.4: Diagrama de Caso de Uso do Cliente Medusa

\section{Mensagens da Camada de Rede}

Tanto o Servidor Medusa quanto o Cliente Medusa devem fornecer um serviço de envio e recebimento de dados para as camadas superiores desta arquitetura, sem responsabilidade pelo empacotamento ou desempacotamento destes dados. No entanto, esta camada utiliza algumas mensagens para comunicar o status da conexão entre Cliente e Servidor.

Ao se conectar a um Servidor, o Cliente deverá enviar uma mensagem informando para o Servidor a existência de uma conexão. Ao se desconectar, o Cliente deve enviar uma mensagem informando da desconexão. Caso um Cliente não consiga se conectar a um Servidor, este Cliente deve relatar o fato para a camada superior (aplicação). Caso o Servidor seja desligado e possua Clientes conectados, o Servidor deve enviar uma mensagem aos clientes informando sua desconexão.

Definimos assim duas mensagens para esta camada: Conexão e Desconexão. A mensagem de conexão é enviada apenas por um Cliente para o Servidor no momento que o mesmo se conecta. Ao receber esta mensagem o Servidor deverá informar a aplicação sobre a presença de um novo Cliente e adicioná-lo a sua lista de Clientes.

A mensagem de desconexão pode ser enviada tanto pelo Cliente quanto pelo Servidor. No caso do Servidor, ao receber tal mensagem ele deverá remover o Cliente da lista e informar a aplicação do fato. No caso do Cliente, ele deverá informar a aplicação e se desconectar.

Tabela 3.1: Mensagens da Camada de Rede

\begin{tabular}{lccc}
\hline \hline Mensagem & Remetente & Destinatário & Endereçamento \\
\hline Conexão & Cliente & Servidor & Privado \\
Desconexão & Cliente & Servidor & Privado \\
\hline \hline
\end{tabular}

\section{Estruturas de Dados da Camada de Rede}

Os tipos iniciais definidos como componentes desta camada, Servidor Medusa e Cliente Medusa, podem ser completados por um tipo que defina a configuração de clientes e servidores e também um 
tipo que defina para o servidor a lista de clientes. Além destes, os tipos que definem as mensagens desta camada também integram a mesma camada, como ilustrado pela Figura 3.5.

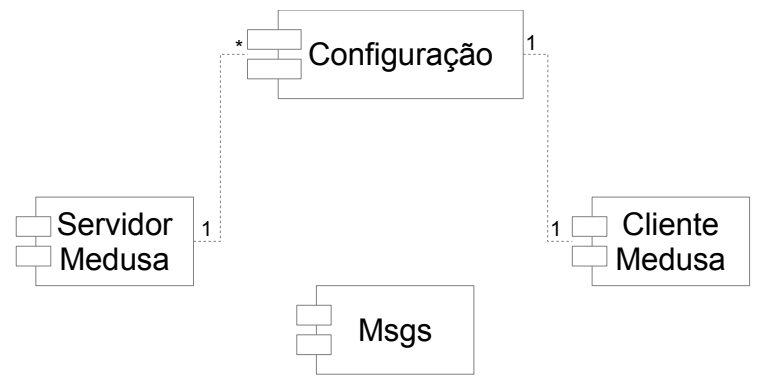

Figura 3.5: Relação entre os Componentes da Camada de Rede

Os tipos de dados auxiliares não foram aqui descritos pois os mesmos fornecem apenas uma representação de dados para o sistema e não possuem casos de uso definidos.

\subsection{Camada de Controle}

A segunda camada na Arquitetura da Medusa é a Camada de Controle, responsável por definir as mensagens e tipos de dados que serão trafegados na rede. As mensagens definidas por esta camada podem ser divididas em 2 tipos: mensagens de dados e mensagens de controle. As mensagens de controle são usadas para configuração e monitoramento do ambiente enquanto as mensagens de dados são utilizadas para trafegar os fluxos de áudio e MIDI. Tal divisão segue a divisão de mensagens apresentada anteriormente, sendo as mensagens de dados endereçadas privativamente enquanto as mensagens de controle são endereçadas tanto de maneira pública quanto privada.

Além disto, mensagens de dados demandam uma alta preocupação com integridade, pois o reenvio de uma mensagem pode não solucionar a perda da mesma, devido ao tempo empregado no reenvio. Já para mensagens de controle, que definem o estado do ambiente, a perda de uma mensagem implica em um monitoramento que não condiz com o estado atual do ambiente. Neste caso o reenvio soluciona o problema pois atualiza o estado do ambiente. Como as mensagens de controle refletem uma ação do ambiente elas podem ser duplicadas sem grandes consequências para o monitoramento. Já as mensagens de dados duplicadas devem ser eliminadas no recebimento.

Outra característica que diferencia mensagens de dados e de controle diz respeito ao seu tempo de envio. É desejável que as mensagens de dados sejam entregues com uma latência mínima possível, enquanto mensagens de controle são mais tolerantes quanto ao tempo de envio e entrega.

Devido a esta variação dos tipos de mensagens, os papéis da camada de controle foram divididos entre um responsável pela mensagens de controle e um responsável pelas mensagens de dados. O responsável pelo envio de mensagens de dados é chamado de Remetente Medusa, o responsável pelo recebimento de mensagens de dados é chamado Destinatário Medusa, enquanto o responsável por envio e recebimento das mensagens de controle é chamado Controle Medusa. Estes componentes irão utilizar os componentes da camada de rede para a comunicação, conforme ilustrado na Figura 3.6.

Com a separação dos papéis entre Remetente e Destinatário, definimos um primeiro fluxo de dados na arquitetura. O Remetente envia recursos para a rede enquanto o Destinatário recebe recursos da rede, conforme ilustrado na Figura 3.7. Estas entidades são associadas aos papéis definidos na camada de rede de cliente e servidor e herdam de tais componentes suas restrições de comunicação. Assim um Remetente pode, como um Servidor, enviar dados para vários Destinatários enquanto um Destinatário, como o Cliente, só pode receber dados de um Remetente.

Já o fluxo de mensagens entre Controles Medusa se dá, na maioria dos casos, de modo público, sendo que qualquer Controle pode tanto receber quanto enviar dados para outros nós do ambiente, conforme ilustrado na Figura 3.8. Para isto, o Controle utiliza a capacidade que o Servidor possui de enviar e receber dados. 


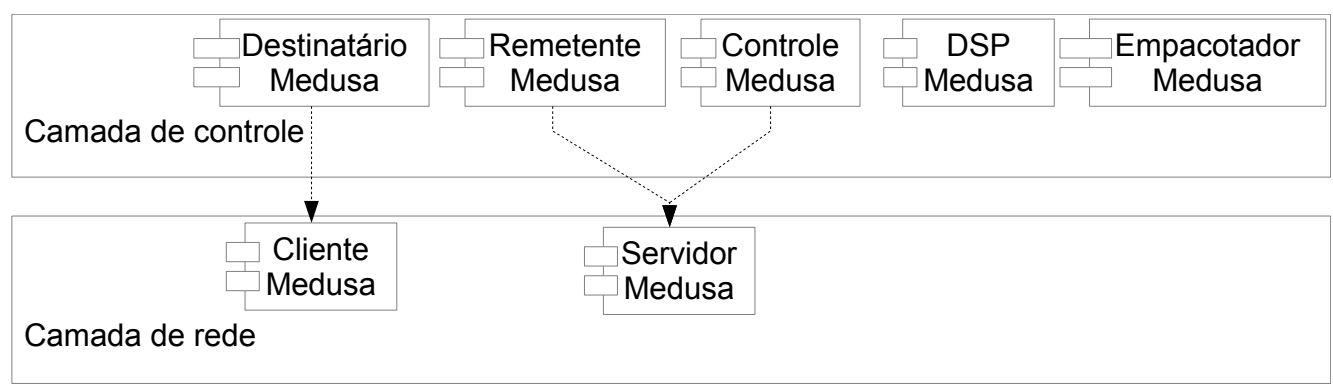

Figura 3.6: Diagrama de Componentes da Camada de Controle

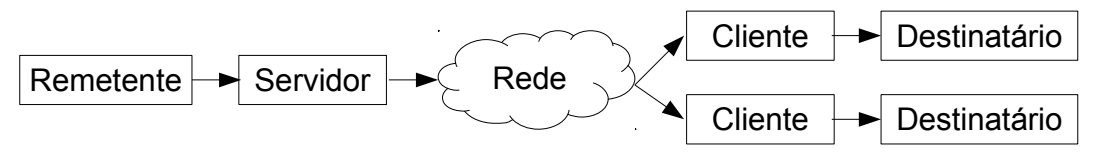

Figura 3.7: Comunicação entre Remetente e Destinatário

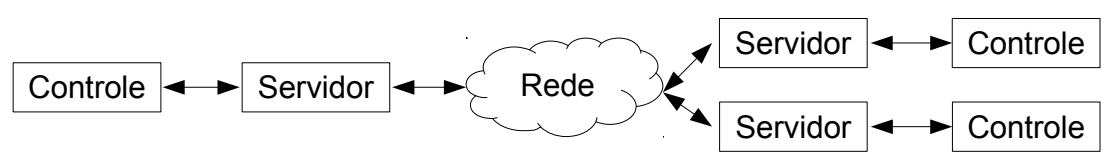

Figura 3.8: Comunicação entre Controles Medusa

Como todo nó do ambiente deve receber e enviar mensagens de controle comunicando seu estado, é necessário que todo nó do ambiente possua uma instância do Controle Medusa. Estações que desejam enviar e receber mensagens de dados no ambiente deverão possuir, além do Controle, um ou mais Remetentes ou Destinatários. Além disto, um Controle deve ser capaz de monitorar mais de um Remetente e Destinatário. A seguir apresentaremos estes componentes individualmente.

\section{Remetente Medusa}

O Remetente Medusa é o responsável pelo envio de fluxos de áudio e MIDI no ambiente e opera sobre um Servidor Medusa. O Remetente pode ser informado pelo Servidor sobre perda de pacotes no envio. Por isto é tarefa do Remetente comunicar estas perdas para as camadas superiores da arquitetura assim como informar sobre a conexão e desconexão de clientes. Como um Servidor também pode receber mensagens, é função do Remetente informar para as camadas superiores o recebimento de mensagens, mantendo assim a consistência da arquitetura em camadas.

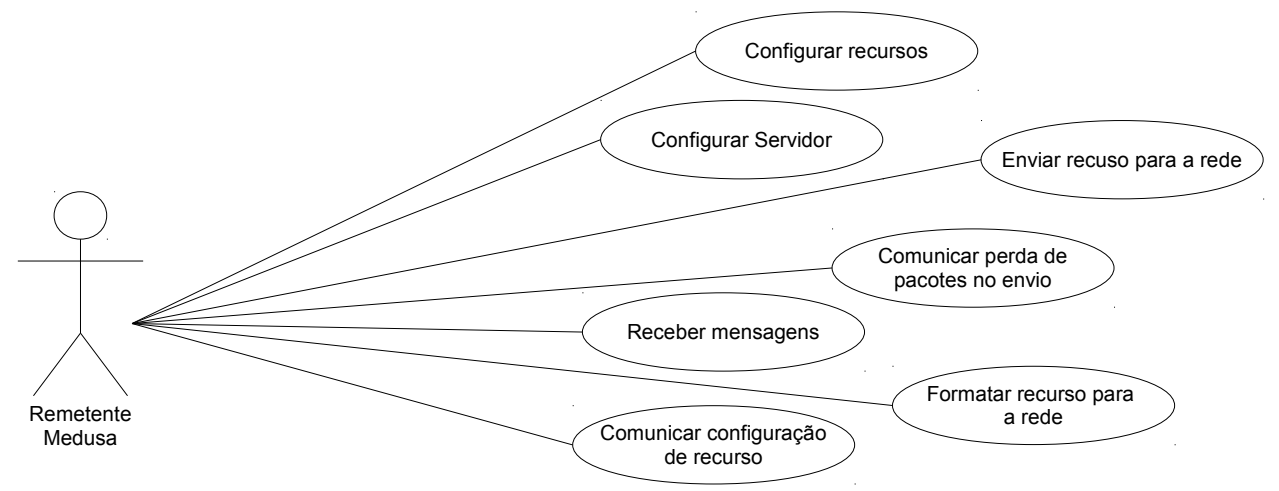

Figura 3.9: Diagrama de Caso de Uso do Remetente Medusa

Caso o usuário deseje alterar o recurso local de áudio para o envio, é tarefa do Remetente configurar e formatar este recurso para o formato de rede. Chamamos aqui de formato de rede o formato que desejamos disponibilizar o recurso, e de formato local a configuração local do recurso na aplicação. Com isto, é possível que um recurso que exista localmente com determinada configuração 
seja enviado para a rede em outro formato. No caso de um novo Ciente se conectar ou de haver uma mudança no formato de envio para a rede, o Remetente deve informar os Destinatários conectados da nova configuração de seu recurso.

A configuração do recurso inclui ainda a quantidade de canais para o envio pela rede, sendo que para cada canal deve haver um buffer para armazenar dados antes do envio. O Remetente deve fornecer para a camada de aplicação uma maneira simples de acessar estes buffers.

Uma vez configurado um recurso, o Remetente deve informar ao seu Controle a disponibilização do recurso ao ambiente para a publicação pelo Controle. As tarefas que um Remetente deve realizar são apresentadas no diagrama de Caso de Uso da Figura 3.9.

\section{Destinatário Medusa}

O Destinatário Medusa é o componente da arquitetura responsável por receber fluxos de áudio e MIDI. O Destinatário é criado de maneira similar ao Remetente, porém sua configuração deve incluir os dados necessários para instanciar um Cliente Medusa e garantir sua conexão. O Destinatário também deverá comunicar às camadas superiores o status da conexão com o Servidor e a perda de conexão. Apesar de sua função principal ser o recebimento de dados, o Destinatário também pode enviar dados para o Servidor.

Este componente deve tentar também garantir para a aplicação a integridade dos dados recebidos. Para isto ele deve verificar a ordenação e perdas de pacotes e tentar resolver localmente possíveis falhas de rede. Caso ocorra uma perda irrecuperável, ele deve informá-lo para a aplicação.

Para cada canal do recurso o Destinatário deve criar um buffer circular e disponibilizar o acesso a estes buffers para a camada de aplicação. Ao contrário do Remetente, os buffers serão utilizados para armazenar temporariamente os dados recebidos da rede antes dos mesmos serem consumidos pela aplicação.

Enquanto um dado se encontra no buffer circular, transformações e processamentos podem ser feitos pelo Destinatário de maneira a ajustar o recurso da rede para sua configuração local.

Não é função do Destinatário resolver diferenças entre o número de canais recebidos e o número de canais locais. Independentemente da quantidade de canais locais o Destinatário irá disponibilizar um buffer circular para cada canal recebido, permitindo assim que a política de acesso aos canais seja definida pela camada superior.

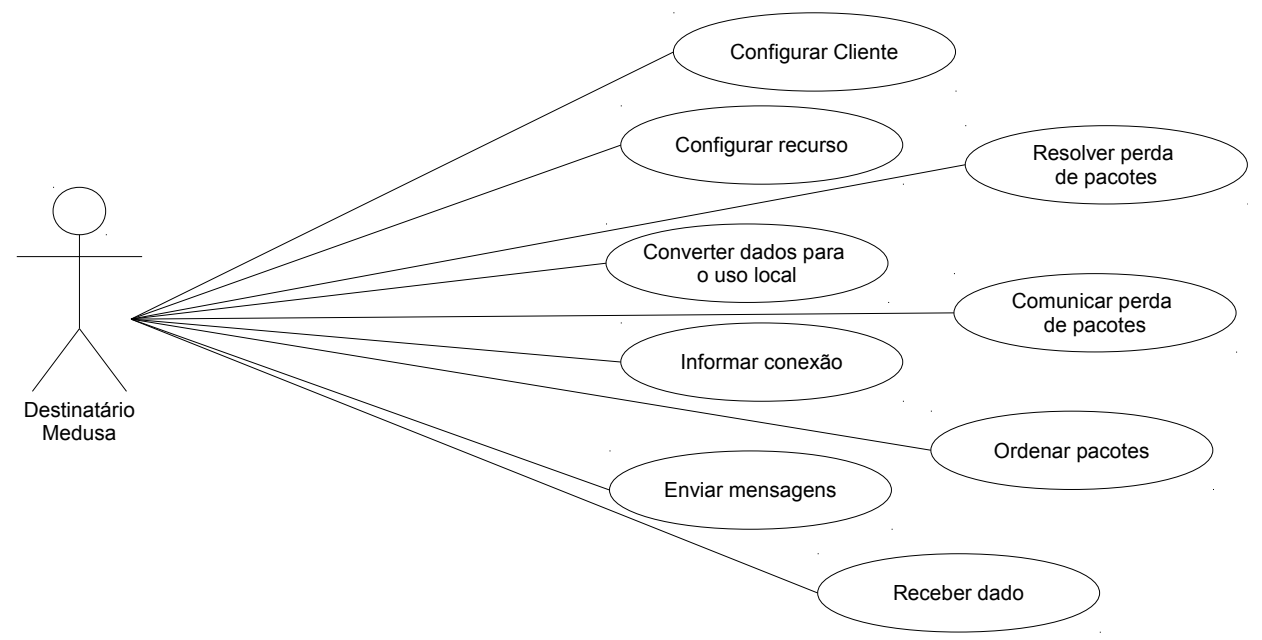

Figura 3.10: Diagrama de Caso de Uso do Destinatário Medusa

As tarefas do Destinatário estão apresentadas no diagrama de caso de uso da Figura 3.10.

\section{Mensagens Entre Remetente e Destinatário}

As mensagens entre Remetente e Destinatário serão mensagens de áudio e MIDI. Apesar de ambas estarem classificadas como mensagens de dados, elas possuem diferenças quanto ao seu 
processamento. Um fluxo de áudio pode depender de adaptação local para ser consumido pela aplicação devido a diferenças na representação do dado de rede em relação à configuração local. Já o fluxo de MIDI não depende de transformações pois dados MIDI são sempre representados da mesma forma, mesmo em aplicações diferentes. A Figura 3.11 apresenta as diferenças no envio e recebimento dos dois tipos distintos de fluxo de dados.

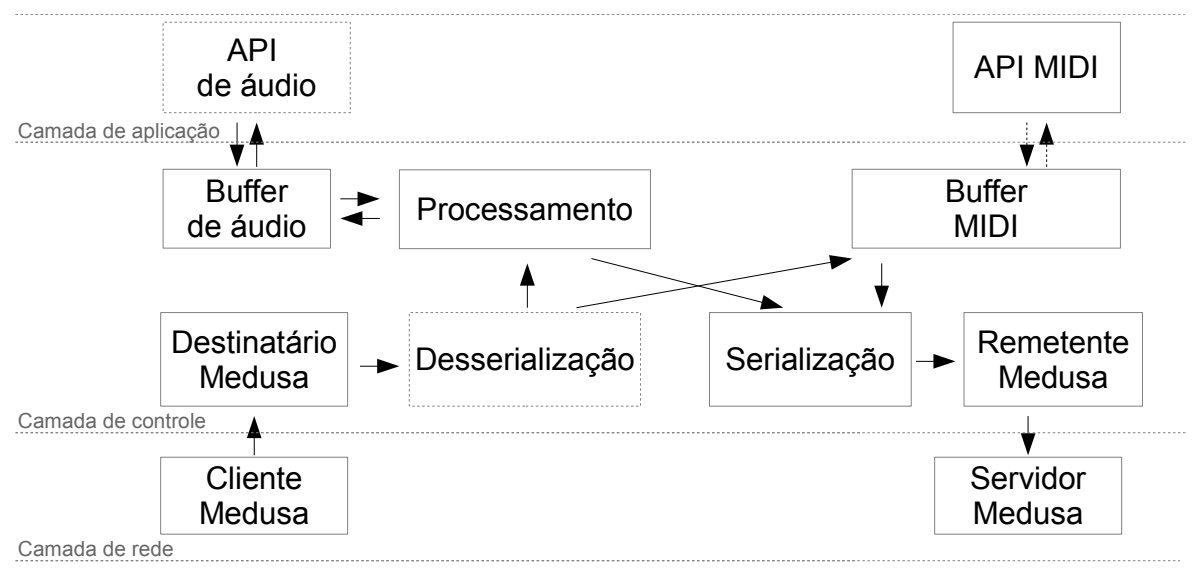

Figura 3.11: Fluxo de Dados na Camada de Controle

Por esta razão, dividiremos as mensagens de dados entre mensagens de áudio e mensagens MIDI de forma que Remetente e Destinatário consigam utilizar fluxos diferentes para os diferentes tipos de mensagens.

O processamento dos fluxos de áudio podem incluir tanto modificações para o envio quanto modificações no recebimento. Tais modificações incluem o desentrelaçamento de canais, mudança de taxa de amostragem, mudança de quantização, compressão e mudanças na representação das amostras (por exemplo adaptação de endianness).

Além das mensagens de dados, atribuímos a estes componentes uma mensagem para a configuração de um recurso de áudio a ser enviada pelo Remetente para cada Destinatário conectado. Com isto o Destinatário consegue garantir as transformações locais do fluxo recebido de maneira transparente. Caso a configuração seja alterada durante a comunicação, o Remetente deve enviar uma mensagem com a nova configuração para manter a integridade dos dados no recebimento.

Para monitorarmos a latência entre envio e recebimento e também a perda de pacotes, utilizamos uma mensagem entre Destinatário e Remetente. Tal mensagem denominada de Loopback servirá para calcular o tempo de ida e volta de uma mensagem de dados.

Tabela 3.2: Mensagens entre Remetente e Destinatário

\begin{tabular}{lccc}
\hline \hline Mensagem & Remetente & Destinatário & Endereçamento \\
\hline Dados de áudio & Remetente & Destinatário & Privado \\
Dados de MIDI & Remetente & Destinatário & Privado \\
Configuração de áudio & Remetente & Destinatário & Privado \\
Loopback & Destinatário & Remetente & Privado \\
\hline \hline
\end{tabular}

\section{Controle Medusa}

O Controle Medusa é responsável por refletir localmente a arquitetura do ambiente distribuído apresentando cada instância da ferramenta e suas interações com as demais instâncias. Desta maneira, apesar do compartilhamento de um recurso ocorrer entre dois computadores, consideramos que outras máquinas podem interagir, monitorar e configurar a transmissão em um ambiente colaborativo.

O responsável na arquitetura proposta por gerenciar estas mensagens de controle é o Controle Medusa. Este componente deverá trocar mensagens com outros Controles de maneira a manter 
localmente uma visão atualizada do estado do ambiente. A visão do estado do ambiente deve incluir todos os nós, recursos e conexões, e pode ser utilizada como um serviço de publicação de recursos. A utilização deste serviço pode permitir a configuração transparente de um Destinatário, informando-o da localização e da configuração de envio de um recurso.

Além de manter o estado do ambiente, o Controle pode também enviar dados específicos de uma determinada aplicação. Mensagens de chat, por exemplo, podem ser usadas por uma aplicação específica que forneça tal funcionalidade ao ambiente.

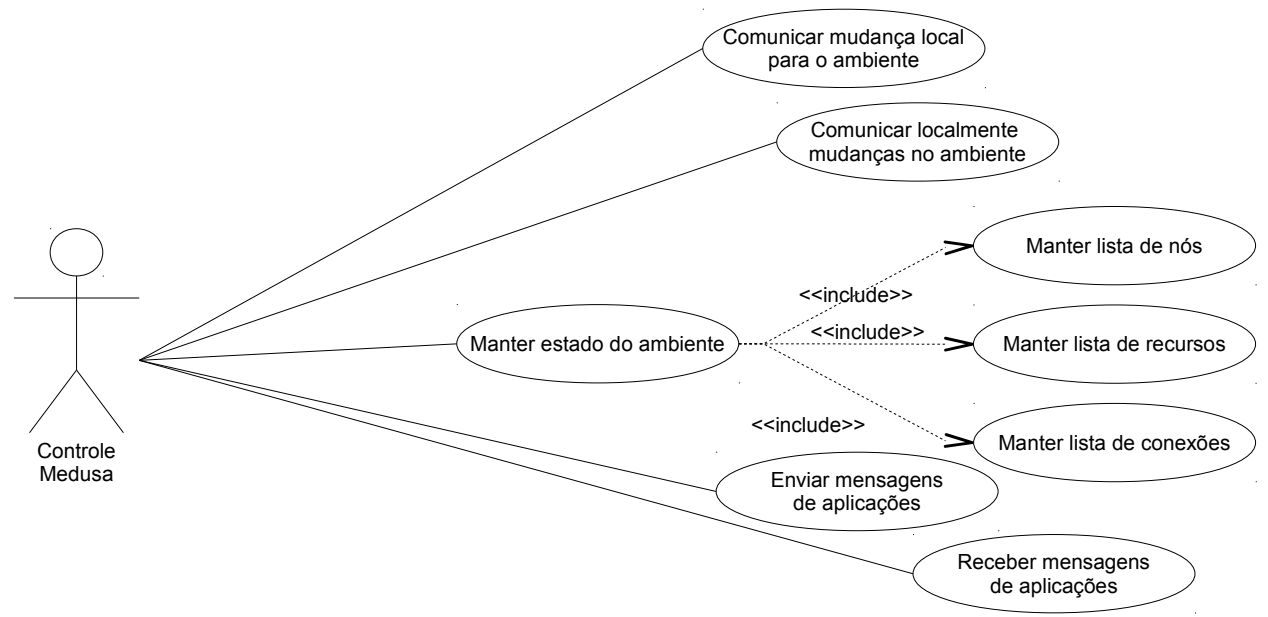

Figura 3.12: Diagrama de Caso de Uso do Controle Medusa

As responsabilidades do Controle Medusa são apresentadas no diagrama de caso de uso da Figura 3.12. Ao contrário do Remetente, que permite ao usuário escolher o protocolo e porta para o envio de um fluxo de dados, o Controle deverá utilizar sempre o mesmo protocolo e ser alocado na mesma porta de maneira a garantir a comunicação com os demais Controles.

\section{Mensagens do Controle Medusa}

As mensagens de controle incluem a publicação de recursos, a configuração de recursos e informações sobre conexões, conforme apresentado na Tabela 3.3.

Ao ser instanciada uma ferramenta, o Controle deve enviar ao ambiente uma mensagem comunicando os demais nós da sua existência. Esta mensagem é chamada de Adicionar Novo Nó e deve ser enviada publicamente ao ambiente. Ao receber esta mensagem pública, outros Controles deverão verificar se este nó já está presente em suas listas. Caso não esteja, deverão adicionar o novo nó e responder ao novo Controle através de uma mensagem privada confirmando o seu mapeamento dentro do ambiente. Ao sair do ambiente, o Controle deve enviar uma mensagem de Remover Nó ao ambiente informando sua saída. Ao receber esta mensagem os demais Controles deverão removê-lo localmente de suas listas de nós conhecidos.

Quando Remetente ou Destinatário criam / consomem um novo recurso, devem comunicar o fato ao seu Controle para que este último comunique ao ambiente. Esta mensagem de Adicionar Novo Recurso deve conter as informações sobre o recurso criado ou consumido. O mesmo ocorre quando um Remetente ou Destinatário deixam de fornecer / consumir um recurso, devendo comunicar ao Controle para que este envie uma mensagem de Remover Recurso ao ambiente. Quando um Destinatário conecta-se a um Remetente, também deve informar ao ambiente através do Controle quando a conexão é criada ou removida.

\section{Estruturas de Dados da Camada de Controle}

As estruturas de dados propostas nesta camada são inicialmente suas entidades: Remetente, Destinatário e Controle. A configuração de um recurso, tanto no Remetente quanto no Destinatário, depende da configuração de áudio e MIDI local e de rede. 
Tabela 3.3: Mensagens do Controle

\begin{tabular}{lccc}
\hline \hline Mensagem & Remetente & Destinatário & Endereçamento \\
\hline Adicionar novo nó & Controle & Controle & Público \\
Adicionar-me a sua lista & Controle & Controle & Privado \\
Remover nó & Controle & Controle & Público \\
Adicionar recurso & Controle & Controle & Público \\
Remover recurso & Controle & Controle & Público \\
Adicionar conexão & Controle & Controle & Público \\
Remover conexão & Controle & Controle & Público \\
\hline \hline
\end{tabular}

A formatação do recurso de áudio depende ainda de um conversor DSP que faça as transformações entre o recurso local e o recurso de rede no Remetente e nos Destinatários. Para que o Controle possa manter a sua visão do ambiente atualizada ele depende da definição de Nós e Recursos.

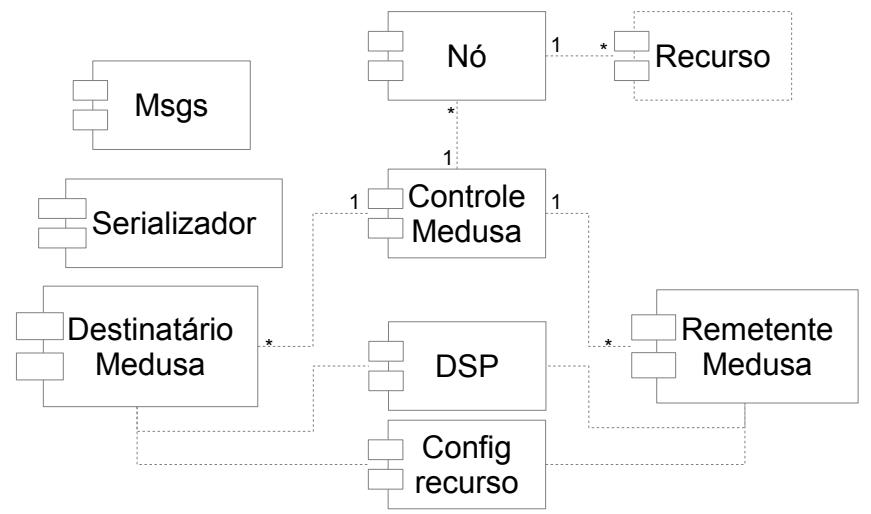

Figura 3.13: Relação entre os Componentes da Camada de Controle

Além destas estruturas, as mensagens também integram esta camada, assim como o Serializador / Desserializador de mensagens, conforme apresentado na Figura 3.13.

Os componentes DSP e Serializador não possuem necessariamente uma estrutura de dados mas possuem funcionalidades que serão usadas por mais de um componente e por isto sua separação pode simplificar o reaproveitamento de código.

Já os componentes de configuração de nó e recurso não possuem necessariamente funcionalidades mas são apenas representações de dados no sistema.

\subsection{Camada de Aplicação}

A terceira camada da arquitetura representa a visão da ferramenta para o usuário. Nesta camada, aplicações específicas podem ser desenvolvidas para a transmissão de dados musicais, para a transmissão de dados específicos ou para o monitoramento do ambiente, utilizando as estruturas definidas nas camadas inferiores. Por esta razão, a Camada de Aplicação contém as interfaces do usuário e os conectores de som, conforme apresentados na Figura 3.14.

Os conectores de som são baseados em APIs de áudio e MIDI discutidas na Seção 2.1.3 deste documento. Alguns conectores possuem uma clara definição de interface gráfica, enquanto outros permitem diferentes implementações de UI. Por esta razão, podemos considerar que a UI será implementada juntamente com o conector de som, ou separadamente.

Os conectores utilizam Remetentes e Destinatários para o envio e recebimento de dados musicais. A UI deverá disponibilizar informações sobre o ambiente e também configurar conectores de som, como ilustra a Figura 3.14. A seguir detalharemos as responsabilidades dos componentes desta camada. 


\begin{tabular}{|c|c|c|c|c|c|}
\hline \multicolumn{6}{|l|}{ Camada de aplicação } \\
\hline \multicolumn{6}{|l|}{$\nabla$} \\
\hline $\begin{array}{c}\text { Destinatário } \\
\square \quad \text { Medusa }\end{array}$ & $\begin{array}{l}\text { Remetente } \\
\square \text { Medusa }\end{array}$ & $\begin{array}{r}\square \mathrm{C} \\
\square \mathrm{N}\end{array}$ & $\begin{array}{l}\text { trole } \\
\text { dusa }\end{array}$ & $\begin{array}{c}\text { DSP } \\
\square \text { Medusa }\end{array}$ & $\begin{array}{c}\text { Empacotador } \\
\square \quad \text { Medusa }\end{array}$ \\
\hline \multicolumn{6}{|l|}{ Camada de controle } \\
\hline \multicolumn{6}{|l|}{$\nabla$} \\
\hline $\begin{array}{l}\square \text { Cliente } \\
\square \text { Medusa }\end{array}$ & \multicolumn{2}{|c|}{$\begin{array}{l}\text { Servidor } \\
\text { Medusa }\end{array}$} & & & \\
\hline \multicolumn{6}{|l|}{ Camada de rede } \\
\hline
\end{tabular}

Figura 3.14: Diagrama de Componentes da Camada de Aplicação

\section{Conector de Som}

O conector de som tem a responsabilidade de disponibilizar para a rede um recurso local. Para isto, o conector é responsável por reproduzir amostras de áudio e MIDI recebidas pela rede e capturar amostras de áudio e MIDI local para o envio.

Como a configuração local do recurso depende da API de som, também é de responsabilidade do conector configurar o recurso local para o envio. Esta configuração será utilizada pela camada de controle para que ela possa entregar para o conector os dados de áudio transformados para o formato local. Apesar da camada de controle se responsabilizar por estas transformações, é de responsabilidade do conector de som resolver a diferença na quantidade de canais caso a mesma ocorra.

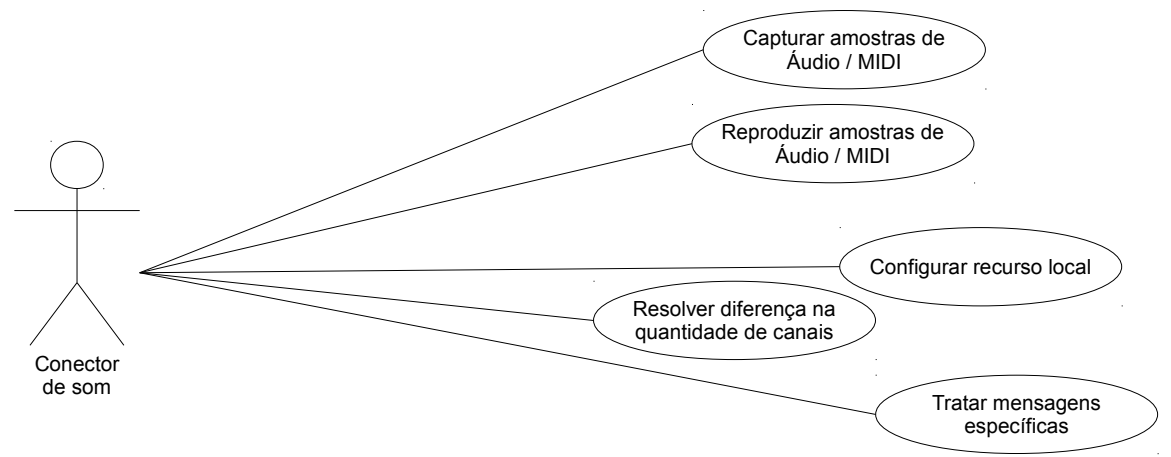

Figura 3.15: Diagrama de Caso de Uso do Conector de Som

Caso o conector possua mensagens específicas para sincronizar outros conectores na rede, o mesmo deverá tratar do envio e recebimento destas mensagens por meio do Controle Medusa. As tarefas do conector de som estão representadas no diagrama de caso de uso da Figura 3.15.

\section{UI}

A UI é o componente responsável pela configuração da ferramenta e a apresentação do ambiente para o usuário. Por meio da UI os recursos locais e conexões são configurados e monitorados. A UI também é responsável por apresentar e monitorar o ambiente como um todo.

Caso haja outras aplicações para serem integradas ao ambiente, esta integração também deverá ser feita pela UI.

\section{Mensagens da Camada de Aplicação}

Aplicações do ambiente podem também definir mensagens específicas. Caso as mesmas possuam as características das mensagens de dados elas deverão ser incorporadas ao fluxo de informação dos 


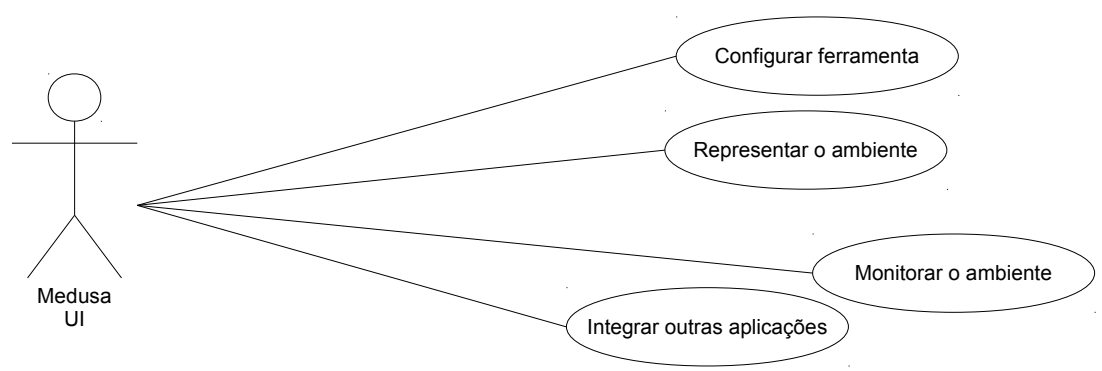

Figura 3.16: Diagrama de Caso de Uso do Medusa UI

Remetentes / Destinatários e transmitidas por estes componentes. Caso estas mensagens possuam as características de mensagens de controle, elas deverão ser enviadas pelo Controle. Uma mensagem de Chat, por exemplo, possui as características de mensagens de controle por ser de interesse do ambiente todo e não ter restrições temporais críticas.

Além de mensagens novas para aplicações específicas, os conectores de som podem requerer mensagens específicas ao ambiente. O servidor de som JACK, por exemplo, possui um controle chamado Transport que permite iniciar / interromper todas as aplicações conectadas a este servidor de maneira sincronizada. Esta mensagem pode ser enviada para o ambiente para sincronizar todas as instâncias deste servidor no ambiente. Já o ambiente Pure Data possui um comando para iniciar ou interromper o processamento de sinais (DSP). Tal comando também pode ser enviado para a rede para sincronizar diversas instâncias desta ferramenta.

Tabela 3.4: Possibilidades de Mensagens da Camada de Aplicação

\begin{tabular}{lccc}
\hline \hline Mensagem & Remetente & Destinatário & Endereçamento \\
\hline Chat & Applicação & Applicação & Pública \\
Start Transport & JACK & JACK & Pública \\
Stop Transport & JACK & JACK & Pública \\
Start DSP & PD & PD & Pública \\
Stop DSP & PD & PD & Pública \\
Bypass on & Plugins & Plugins & Pública \\
Bypass off & Plugins & Plugins & Pública \\
\hline \hline
\end{tabular}

As mensagens da Tabela 3.4 são apenas exemplos de como as aplicações podem ampliar a capacidade de sincronização de aplicações no ambiente. Vale notar que é possível implementar aplicações específicas para o envio destas mensagens sem que esta aplicação deva necessariamente enviar ou receber dados musicais.

Com a camada de aplicação encerramos a proposta arquitetural do ambiente Medusa. Na próxima Seção discutiremos a implementação desta arquitetura.

\subsection{Considerações}

Findada a apresentação da arquitetura proposta, retomamos a arquitetura básica da Figura 1.1 para algumas considerações.

A arquitetura básica apresentada baseia-se em um modelo arquitetural chamado pipes and filters ou arquitetura de pipeline. Esta arquitetura permite criar sistemas complexos combinando componentes simples de maneira análoga a um circuito eletroeletrônico. Neste modelo arquitetural, utilizado no terminal do Unix, cada componente atua como um filtro sobre um fluxo de informação. Assim, os componentes desta arquitetura recebem uma entrada de dados, transformam estes dados por meio de um ou mais algoritmos e geram como saída o resultado deste processamento. Há ainda componentes iniciais e finais do sistema, responsáveis por adquirir e enviar dados de / para dispositivos de entrada e saída. 
Uma vantagem do desenvolvimento baseado nesta arquitetura está na simplicidade de seus componentes. Como normalmente cada componente do sistema é responsável por realizar apenas uma tarefa, o desenvolvimento destes componentes é mais simples e o desenvolvedor pode testar cada componente individualmente. Uma desvantagem desta arquitetura pode ser observada em sua utilização por usuários leigos, pois depende do usuário conhecer os componentes disponíveis e combiná-los a fim de obter o resultado desejado.

A preocupação com a usabilidade do sistema motivou a utilização de uma arquitetura em camadas, que também está baseada em componentes, mas a combinação destes componentes cabe ao programador e não ao usuário. Apesar da arquitetura proposta estar organizada em camadas, é possível verificar a existência intrínseca de pipelines nos fluxos de informação da Medusa, como por exemplo na transmissão de áudio e MIDI.

Outros exemplos de arquiteturas comuns no desenvolvimento de software são a Arquitetura Cliente-Servidor e a Arquitetura Ponto-a-Ponto. Na arquitetura de um sistema Cliente-Servidor, as tarefas de uma aplicação são dividas entre estes dois agentes de maneira que a aplicação depende da interação destes para realizar suas funcionalidades. A Arquitetura Ponto-a-Ponto funciona de maneira similar, porém não há uma hierarquia pré-fixada entre os nós, sendo que qualquer nó a qualquer momento pode assumir tanto o papel de cliente quanto o papel de servidor.

A arquitetura da Medusa corresponde à Arquitetura Ponto-a-Ponto na comunicação do ambiente, possuindo características desta arquitetura como a descentralização, heterogeneidade e escalabilidade. Por isto, podemos dizer que a arquitetura em camadas aqui apresentada representa a arquitetura de um único nó dentro do ambiente, e que a arquitetura do ambiente é Ponto-a-Ponto. 


\section{Capítulo 4}

\section{Implementação}

Analisando no Capítulo 2 os primeiros protótipos da ferramenta concluímos que a implementação monolítica não permitiria a reutilização do código da ferramenta em implementações que utilizassem outras APIs de áudio. Esta necessidade guiou o desenvolvimento para uma implementação em que as camadas de controle e de rede fossem desenvolvidas de maneira separada da camada de aplicação, tomando a forma de uma biblioteca (libmedusa), conforme apresentado na Figura 4.1.

\begin{tabular}{c|c}
\hline Camada de aplicação & Aplicações \\
\hline Camada de controle & libmedusa \\
\hline Camada de rede &
\end{tabular}

Figura 4.1: Separação entre a Libmedusa e as Implementações de Ferramentas

Esta estrutura modular permitiu a implementação de aplicações musicais que integram a libmedusa com conectores de som e também a implementação de aplicações de controle para o monitoramento do ambiente.

A implementação da libmedusa foi feita em C, devido à maior compatibilidade desta linguagem com as bibliotecas utilizadas no desenvolvimento da camada de rede.

O código-fonte da biblioteca e das aplicações encontram-se disponível no repositório sourceforge $^{1}$.

Neste Capítulo apresentaremos em detalhes o desenvolvimento da libmedusa.

\subsection{Libmedusa}

A organização do código da libmedusa segue basicamente a divisão em camadas da arquitetura proposta no Capítulo 3. Aos componentes originais daquela arquitetura foram adicionados alguns outros componentes de apoio, correspondendo a funcionalidades auxiliares utilizadas no desenvolvimento da biblioteca, e apresentados na Seção a seguir. Em seguida serão apresentadas as implementações da camada de rede e de controle que seguem a definição arquitetural proposta no Capítulo anterior.

\subsubsection{Componentes de Apoio}

Os componentes apresentados a seguir são implementações de funcionalidades auxiliares para o desenvolvimento da libmedusa e que não se encontram na arquitetura inicial.

\footnotetext{
${ }^{1}$ http://sourceforge.net/projects/medusa-audionet/ Acessada em 01/12/2013.
} 


\section{Lista Encadeada}

Uma das estruturas auxiliares necessárias para o desenvolvimento da Medusa corresponde a uma lista encadeada genérica, cujo código inclui funções para criação de listas, além de adição, remoção e busca de elementos na lista.

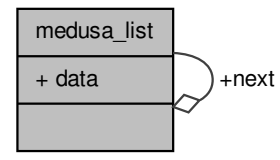

Figura 4.2: Lista Encadeada da Medusa

\section{Marcação de Tempo}

A estrutura padrão em C para a definição de instantes no tempo é chamada timespec (definida na biblioteca time.h), que utiliza dois campos, um inteiro de 32 bits para armazenar os segundos e uma estrutura de 32 ou 64 bits (dependendo da arquitetura da máquina) para armazenar os nanossegundos.

Como a variação no tamanho desta estrutura pode comprometer a integração de computadores de arquiteturas diferentes em rede, foi implementada uma estrutura de tempo similar mas que garante que seus campos são sempre representados por valores inteiros de 32 bits. Tal estrutura é apresentada na Figura 4.3.

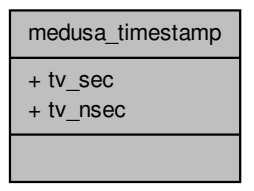

Figura 4.3: Marcação de Tempo na Medusa

Juntamente com esta estrutura de dados, foram criadas funções básicas para definir instantes de tempo, comparar ou subtrair instantes de tempo e converter instantes de tempo para os tipos inteiro e ponto flutuante.

\section{Buffer Circular}

A alocação de memória para o envio e recebimento de dados depende de uma sincronização das leituras e escritas entre o dispositivo de som e o dispositivo de rede, feita comumente por meio de um buffer circular.

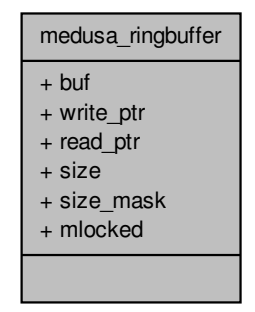

Figura 4.4: Buffer Circular da Medusa

O buffer circular da Medusa, cuja estrutura de dados é apresentada na Figura 4.4, foi feita com base no código do buffer circular do JACK. Ao código original foram adicionadas algumas funcionalidades como, por exemplo, a leitura de dados atrás do ponteiro de leitura (caso o buffer esteja vazio). 
Esta estrutura de dados auxiliar é integrada ao código por meio de funções para a criação de um buffer circular, leitura / escrita de dados no buffer, verificação de espaço disponível (para a escrita) e liberação da estrutura (com desalocação de memória).

\subsubsection{Camada de Rede}

De acordo com a intenção manifestada no Capítulo 2 de permitir a exploração de alternativas nos protocolos de transporte, esta camada foi implementada com os 4 protocolos de transporte descritos anteriormente (UDP, TCP, DCCP e SCTP), incluindo as alternativas de endereçamentos em Multicast e Broadcast no protocolo UDP. A definição multiprotocolo desta camada visa adequar a ferramenta a diversos cenários de aplicação, permitindo aos usuários a escolha de protocolos com características distintas como, por exemplo, um protocolo mais rápido sem compromisso de integridade dos dados para aplicações sem tolerância a latência, ou um protocolo que garante a integridade dos dados ao custo de uma latência maior, para aplicações sem tolerância a erros de registro ou transmissão.

A implementação desta camada contou com o uso das bibliotecas em C para a criação de sockets de rede do sistema operacional. As funções de envio e recebimento são implementadas sobre a API POSIX de threads permitindo assim que envio e recebimento ocorram paralelamente.

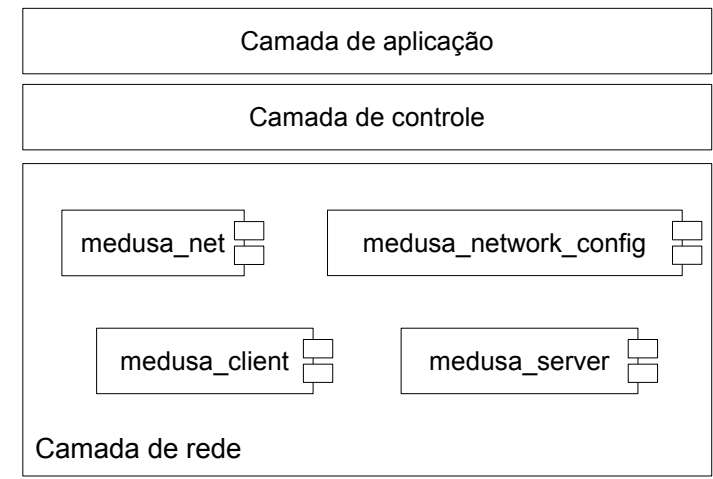

Figura 4.5: Visão da Implementação da Camada de Rede

O conjunto de funções de uso comum por clientes e servidores foram implementadas no módulo medusa_net, apresentado na Figura 4.5, e incluem funções genéricas para instanciação, recebimento e envio de dados por rede. Isto permitiu que a criação dos sockets fosse feita por uma única função, garantindo que clientes e servidores utilizem as mesmas flags de configuração e simplificando a migração da ferramenta para o protocolo IPv6.

Algumas opções de implementação que foram utilizadas na configuração do socket incluem a flag que elimina pacotes após um determinado tempo aguardando o envio (SO_SNDTIMEO, configurada para 40ms) e a flag que configura a prioridade do pacote na fila de envio (SO_PRIORITY, configurada com o valor 6 , que é a máxima prioridade configurável sem privilégios de administrador). Os protocolos TCP e SCTP também utilizaram a flag NODELAY para desabilitar o algoritmo de Nagle $^{2}$. Já para o endereçamento Multicast foram configuradas a flag para o envio local (IP_MULTICAST_LOOP) e a flag que permite que mais de um socket receba dados por um mesmo endereço de rede local (SO_REUSEADDR).

\section{Configuração de Rede}

A estrutura para a configuração da rede é utilizada tanto pelo cliente quanto pelo servidor. Esta estrutura, apresentada na Figura 4.6, possui um socket, um protocolo e também um endereço de rede que é composto por uma porta e um endereço IP.

\footnotetext{
${ }^{2} \mathrm{O}$ algoritmo de Nagle é responsável por agrupar o máximo de dados possíveis em um pacote antes do mesmo ser enviado, o que compromete fortemente o tempo de envio de pacotes nos protocolos TCP e SCTP.
} 


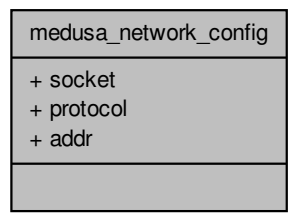

Figura 4.6: Configuração de Rede da Medusa

No Cliente, esta estrutura é utilizada para armazenar os dados de configuração do Servidor. O Servidor utiliza esta estrutura para guardar informações sobre seu próprio endereço e uma lista genérica para armazenar os endereços de todos os Clientes conectados a ele.

Para a configuração de protocolo foi criado um tipo MEDUSA_PROTOCOL que possui a lista de protocolos aceitos pela ferramenta: MEDUSA_NONE, para protocolo indefinido, MEDUSA_UDP, MEDUSA_TCP, MEDUSA_DCCP, MEDUSA_SCTP1 (SCTP com o socket configurado como SOCK_STREAM), MEDUSA_SCTP2 (utilizando o socket SOCK_SEQPACKET), MEDUSA_BROAD para o endereçamento UDP em Broadcast e MEDUSA_MULTI para endereçamentos UDP em Multicast.

\section{Servidor}

O medusa_server é a estrutura de dados que implementa o Servidor Medusa do ambiente, apresentado na Figura 4.7.

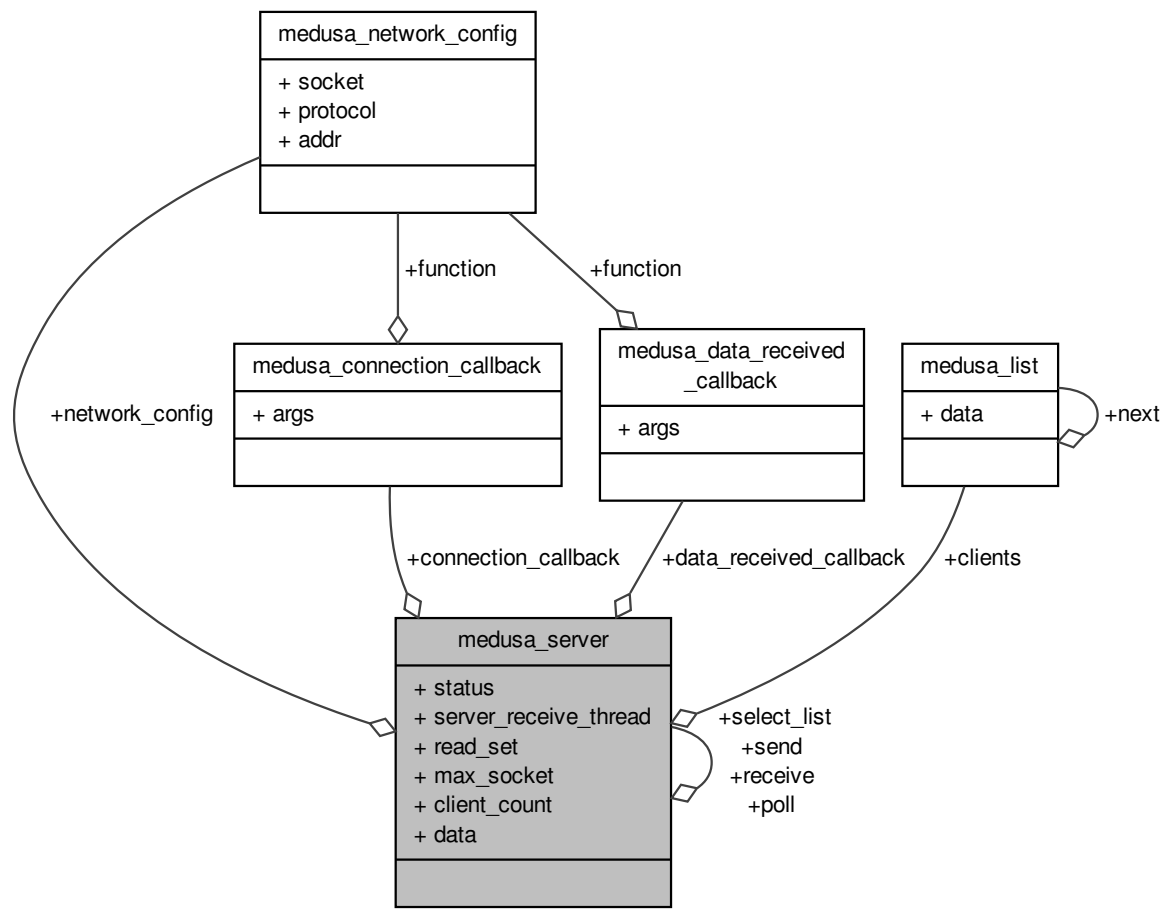

Figura 4.7: Estrutura do medusa_server

A configuração de um servidor irá utilizar a estrutura de configuração de rede previamente apresentada, permitindo ao servidor incluir o endereço dos clientes conectados a ele. Note que, como o cliente não precisa conhecer seu próprio endereço de rede, cabe ao servidor identificar o endereço do cliente no momento da conexão.

A implementação do medusa_server utilizando vários protocolos de transporte e modos de endereçamento exigiu que algumas funcionalidades do servidor, como a conexão, envio e recebimento de dados, fossem implementadas individualmente. Com o intuito de garantir uma interface clara para a camada superior e evitar verificações condicionais quanto à função a ser utilizada em cada envio ou recebimento de dados, foram definidas assinaturas de funções genéricas que devem ser imple- 
mentadas para cada protocolo ou endereçamento. Estas assinaturas foram incluídas na estrutura de dados do servidor, e na definição do protocolo utilizamos uma associação entre as implementações individuais e as assinaturas da estrutura de dados. Desta maneira, a verificação condicional é feita apenas uma vez, na configuração do servidor, conforme apresentado no Código 4.1.

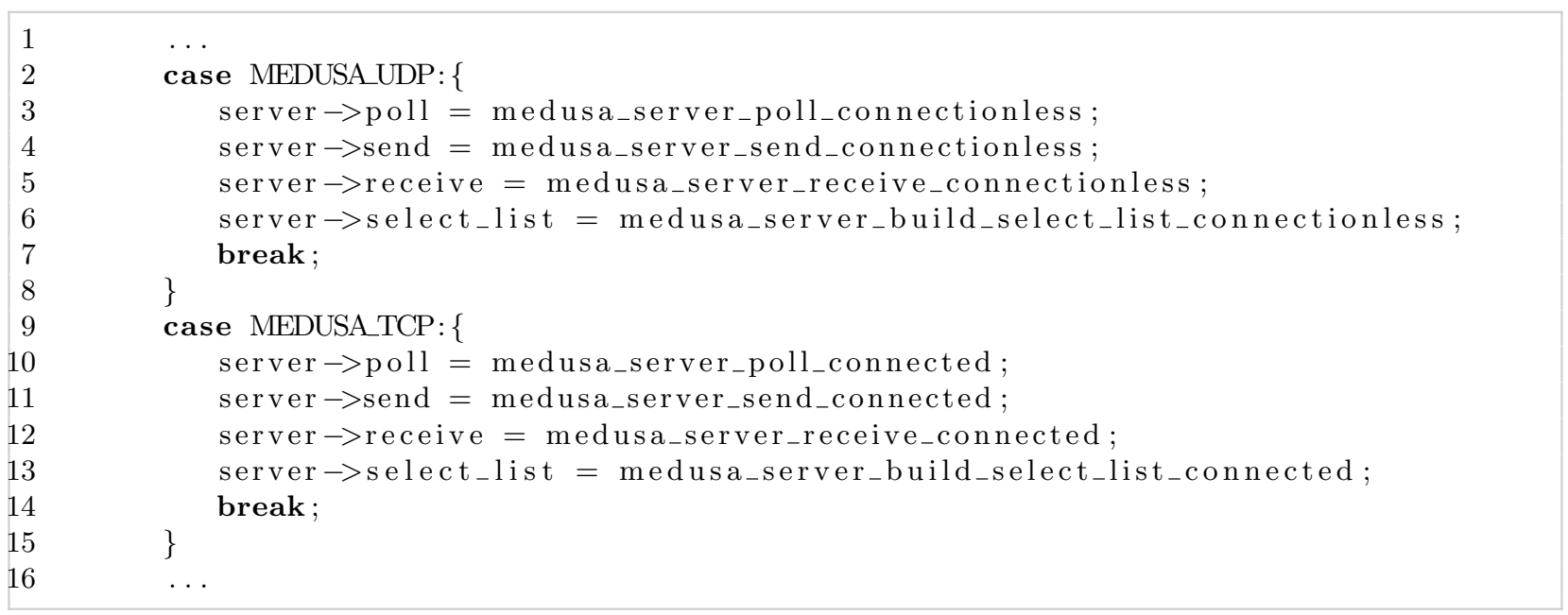

Código 4.1: Definição de Funções na Criação de um medusa_server

Tal definição permitiu que esta estrutura se comporte de maneira similar a uma classe polimórfica em orientação a objetos. Foram definidas funções genéricas para o envio de dados, por exemplo, que utilizam a função associada de maneira transparente, como apresentado no Código 4.2. Isso permite tratar particularidades da implementação, como por exemplo o envio parcial do TCP, de maneira transparente em relação às camadas superiores.

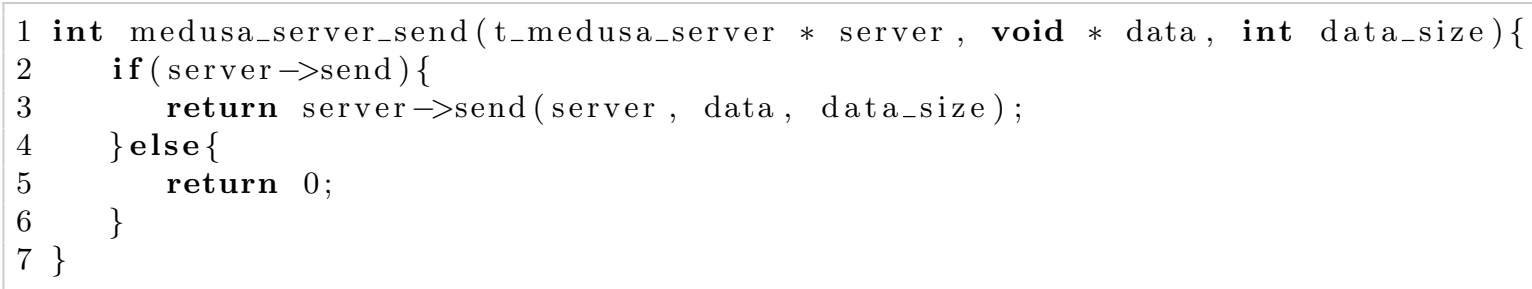

Código 4.2: Utilização das Funções Definidas na Criação do medusa_server

O passo de definição das funções é uma das atividades que a criação de um medusa_server possui, como ilustrado na Figura 4.8.

Além da definição das funções específicas por protocolo, a criação de um servidor inclui ainda a configuração de flags extras, específicos para o servidor. Por exemplo, apenas o socket do servidor será configurado para o recebimento sem bloqueio (flag O_NONBLOCK) que permite ao servidor aguardar conexões e receber mensagens em uma mesma thread e monitorar os socket de todos os clientes conectados.

Outra configuração do servidor que varia de acordo com o protocolo de transporte é a quantidade de sockets utilizados no envio de dados. Em protocolos com conexão, como o TCP, a conexão ocorrerá no socket do servidor e a função accept irá criar um novo socket para receber / enviar dados para cada cliente. No caso de protocolos sem conexão, como o UDP, a mensagem de Conexão será recebida pelo servidor para notificar um novo cliente, e o mesmo socket será utilizado para enviar e receber dados de todos os clientes, sendo que a função de envio utiliza o endereçamento por cliente. Em ambos os casos, o novo cliente será adicionado à lista de envio e ocorrerá a comunicação de conexão às camadas superiores.

A comunicação de eventos como uma nova conexão e a troca de mensagens com as camadas superiores também foram implementadas de maneira genérica por meio de mensagens callback. Assinaturas de funções foram definidas para cada evento e, na ocorrência deste evento, o server chamará a função callback associada. Isto garante um baixo acoplamento entre este objeto e os objetos da camada superior que o utilizam. 


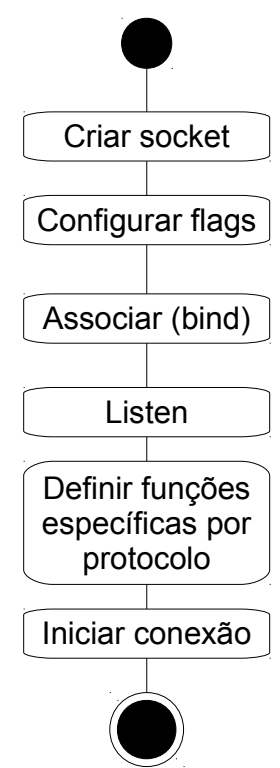

Figura 4.8: Diagrama de Atividades - Criar servidor

\section{Cliente}

O medusa_client é a estrutura de dados que implementa o Cliente Medusa do ambiente. Utilizando a mesma técnica da implementação do Servidor, o Cliente também possui um grupo de funções de assinaturas definidas que são implementadas de maneira diferente para cada protocolo. A estrutura de dados do medusa_client é apresentada na Figura 4.9.

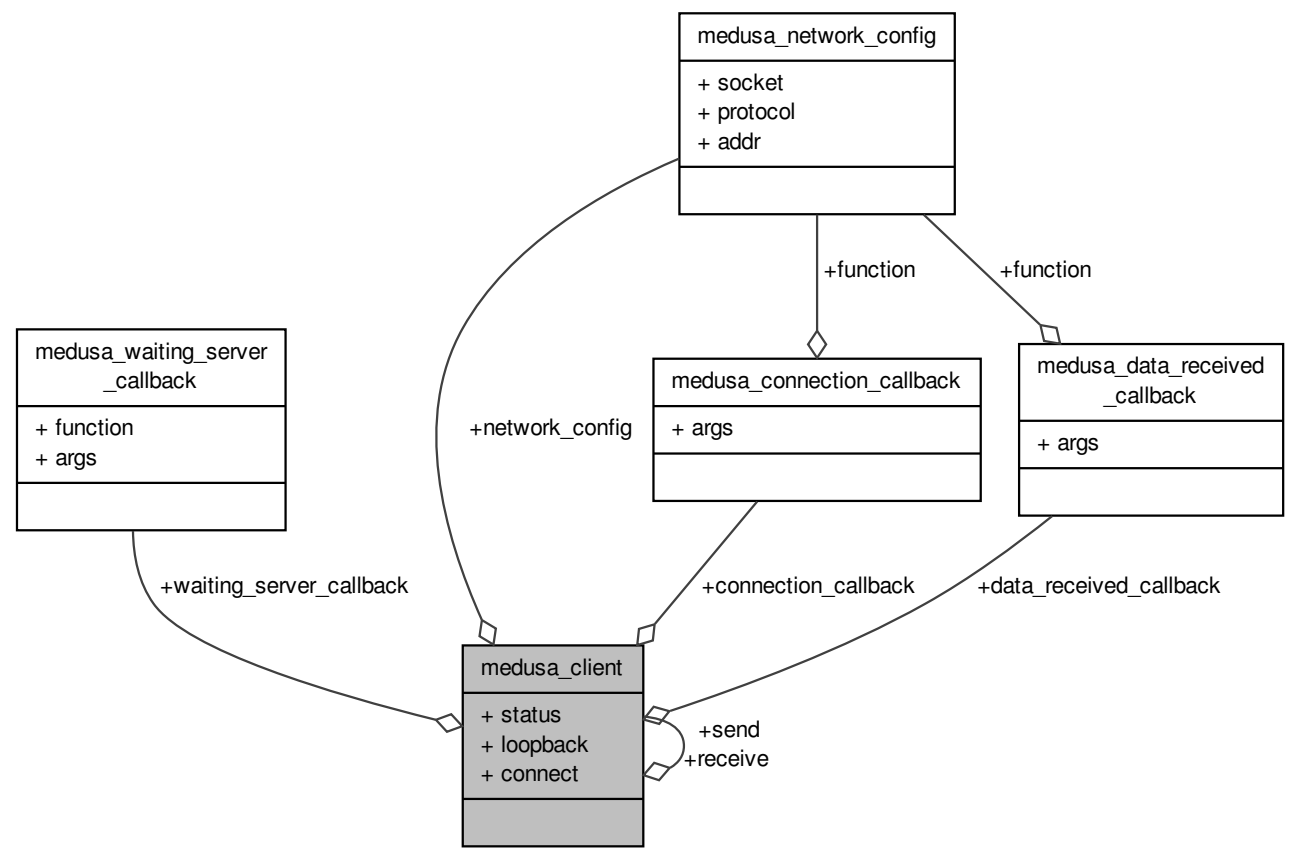

Figura 4.9: Estrutura do medusa_client

Seguindo o modelo de baixo acoplamento, o cliente também notifica eventos para as camadas superiores por meio de funções callback.

\subsubsection{Camada de Controle}

A camada de controle reúne várias funcionalidades do sistema, implementando o sistema de mensagens que refletem localmente o estado do ambiente, as abstrações para envio e recebimento de 
dados musicais, as transformações do sinal de áudio, a definição e o empacotamento das mensagens do ambiente.

A implementação da camada de controle, apresentada na Figura 4.10, expande a visão arquitetural do Capítulo 3 e separa a configuração de recurso em configurações de recursos de áudio e MIDI (medusa_audio_resource e medusa_midi_resource). Como observado na arquitetura, o módulo de DSP não representa uma entidade do sistema, mas um conjunto de funcionalidades para conversões e transformações de sinais de áudio.

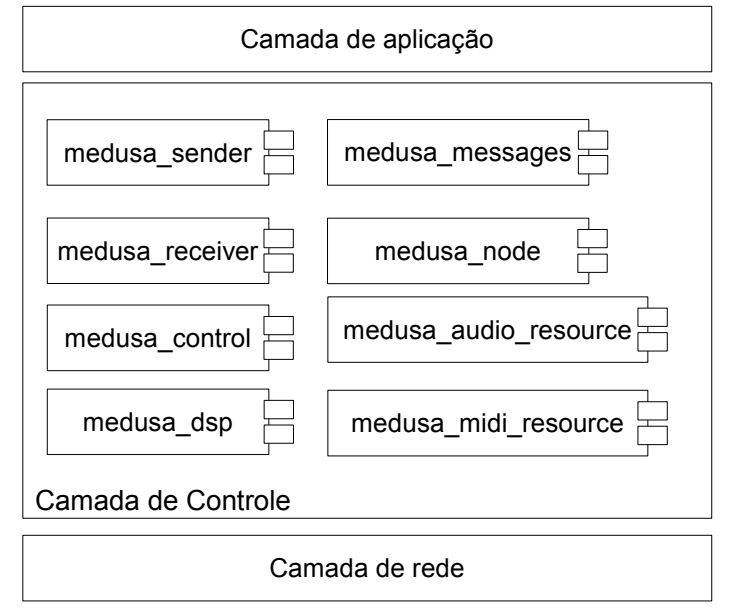

Figura 4.10: Visão da Implementação da Camada de Controle

As entidades medusa_control, medusa_sender e medusa_receiver são mapeamentos diretos da visão arquitetural do sistema apresentada no Capítulo anterior com o medusa_control sendo responsável por implementar o Controle Medusa, o medusa_sender implementando o Remetente Medusa e o medusa_receive implementando o Destinatário Medusa. A serialização de mensagens, definida na arquitetura, está representada na Figura 4.10 juntamente com as definições das mensagens do ambiente.

Iniciaremos a visão desta camada pelas estruturas de dados utilizadas para representar os recursos do ambiente.

\section{Ambiente}

O ambiente é representado por uma coleção de nós, onde cada nó pode possuir uma coleção de recursos de áudio e/ou MIDI. Há um mapeamento desta representação para as entidades da camada de controle, onde os nós representam instâncias do medusa_control enquanto os recursos representam medusa_senders e medusa_receivers associados a este medusa_control. Nesta representação, a diferenciação entre sender e receiver é feita por meio do campo resource_type, permitindo a representação de todas as instâncias da ferramenta nestas estruturas.

A identificação de um nó ou recurso do ambiente depende de uma chave numérica de unicidade, identificada na estrutura de dados pelo campo uid. Apesar de o ambiente utilizar internamente o uid para identificar nós e recursos, os usuários podem utilizar nomes significativos para esta identificação. Por esta razão, ao adicionar um novo nó ou recurso ao ambiente é necessário verificar antes se o nome pretendido não está sendo utilizado localmente por outro nó ou recurso. Tal verificação ocorre apenas localmente e serve para garantir a unicidade dos rótulos adotados pelo usuário para identificação dos recursos. Estas estruturas são apresentadas na Figura 4.13.

\section{Controle}

O medusa_control implementa a entidade responsável pelo controle do ambiente na arquitetura proposta. A esta estrutura está associada a visão do ambiente por meio de uma lista de nós e seus 


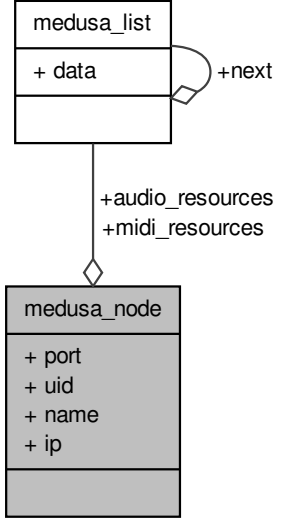

(a) Nó do Ambiente

\begin{tabular}{|l|}
\hline medusa_node_audio_resource \\
\hline + resource_type \\
+ bit_depth \\
+ endianness \\
+ CODEC \\
+ protocol \\
+ channels \\
+ block_size \\
+ port \\
+ sample_rate \\
+ uidd \\
+ name \\
+ ip \\
\hline
\end{tabular}

(b) Recurso de Áudio medusa node_midi_resource

+ resource_type

+ protocol

+ channels

+ port

+ uid

+ name

+ ip

(c) Recurso MIDI

Figura 4.11: Estrutura de Dados do Ambiente 
recursos. Na instanciação de um medusa_control, pode-se definir um nome para identificação; caso a aplicação não defina um nome específico, o nome do usuário do sistema operacional é utilizado.

O medusa_control também mantém uma lista de medusa_senders e medusa_receivers locais associados a ele. Quando senders e receivers são adicionados a um control, este último comunica ao ambiente a presença de um novo recurso.

A implementação do medusa_control foi feita utilizando um medusa_server endereçado por Multicast utilizando a porta 30001. Graças à configuração deste endereçamento e à capacidade do medusa_server de permitir que vários processos endereçados em Multicast utilizem a mesma porta de rede, é possível ter vários controls na mesma máquina e garantir a comunicação entre eles.

Para a interação com esta estrutura foi implementada uma série de funções para envio e recebimento das mensagens do ambiente. A comunicação de um evento no ambiente para as camadas superiores ocorre por funções callback, permitindo que as aplicações se cadastrem para receber apenas os eventos que lhes interessem.

\section{Recursos}

As configurações de Senders e Receivers dependem da configuração de seus recursos, apresentados na Figura 4.13. Devido às diferenças de configuração dos recursos de áudio e MIDI, estruturas distintas são utilizadas para representá-los.

\section{DSP}

O processamento de sinais na Medusa é um conjunto de funções para o tratamento de áudio utilizadas para adequar o áudio recebido da rede para uma configuração local. Entre estes processamentos encontram-se:

Entrelaçamento: Algumas APIs de áudio trabalham com áudio entrelaçado. Foi implementada uma função para entrelaçar / desentrelaçar fluxos de áudio, permitindo a implementação da Medusa para estas APIs.

Taxa de amostragem: Mudança de amostragem no recebimento, devido à diferença de configuração entre máquinas, ou no envio, para a diminuição na largura de banda necessária.

Quantização: Altera o tamanho da representação de cada amostra. Como no caso da reamostragem, este ajuste pode ser feito no recebimento ou no envio para diminuição no consumo de banda de rede.

Compactação de áudio : O algoritmo de compactação CELT foi implementado e pode ser utilizado para diminuir o tráfego na rede.

Byte swap: Outra possível heterogeneidade no sinal que pode ser compensada com baixo custo de processamento é a mudança de representação entre little endian e big endian em plataformas distintas.

A Figura 4.14 apresenta a sequência de transformações para o sinal de áudio no envio e recebimento.

Estas funções, apesar de serem utilizadas por senders e receivers, estão separadas da camada de controle para serem tratadas individualmente.

Além das funções para adequar o localmente o recurso de áudio, outras funções integram as implementações de DSP da Medusa. Entre elas, funções de fade in e fade out, a geração de ruído branco para testes de envio sem conectores de som, o cálculo de energia do sinal para o monitoramento de transmissões, a mixagem de canais de áudio e o controle de ganho do sinal. 


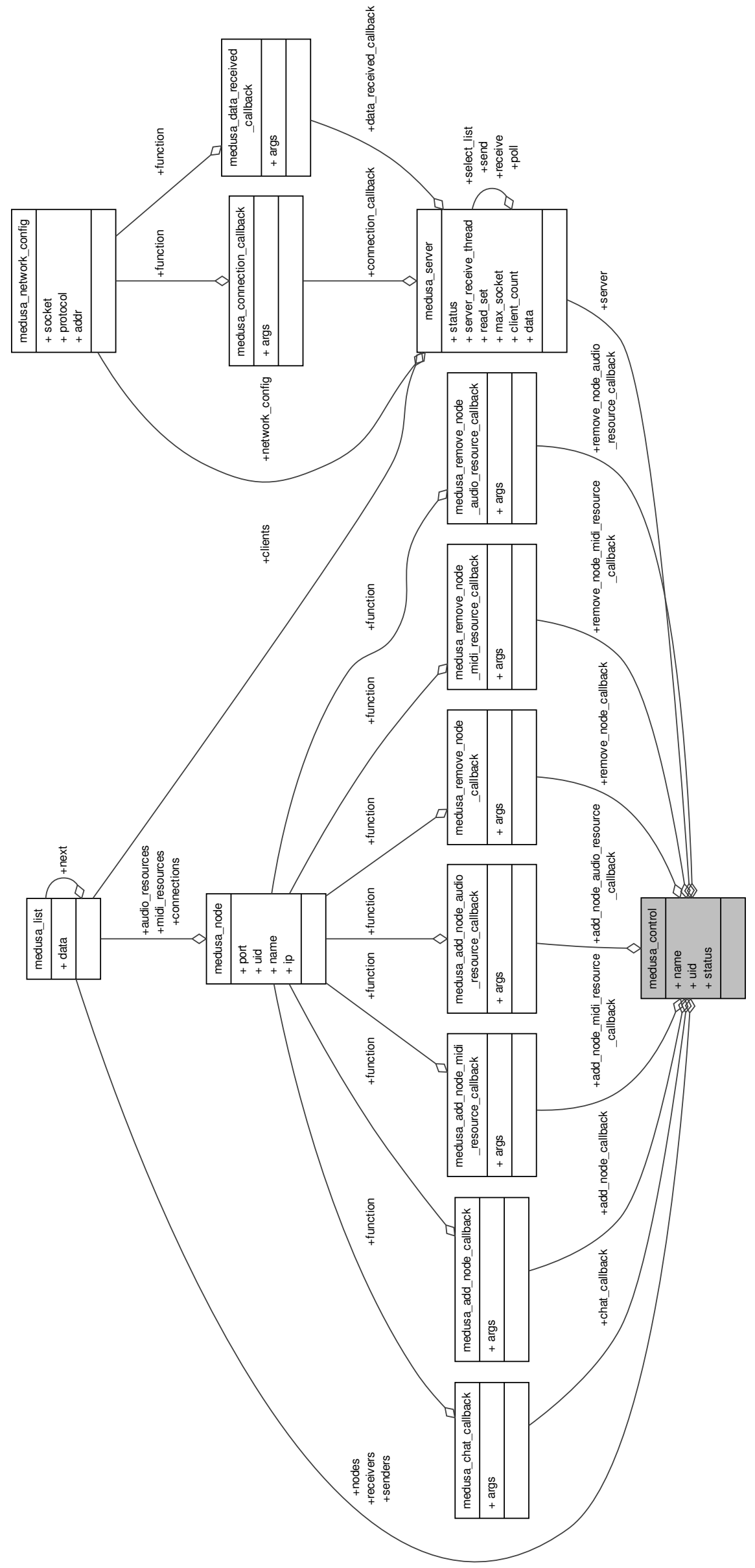

Figura 4.12: Estrutura de Dados do Medusa_control 


\begin{tabular}{|l|}
\hline medusa_audio_resource \\
\hline + CODEC \\
+ endianness \\
+ bit_depth \\
+ channels \\
+ block_size \\
+ sample_rate \\
\hline
\end{tabular}

(a) Recurso de Áudio

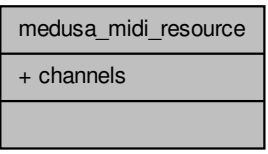

(b) Recurso MIDI

Figura 4.13: Estrutura de Dados de Recursos no Ambiente

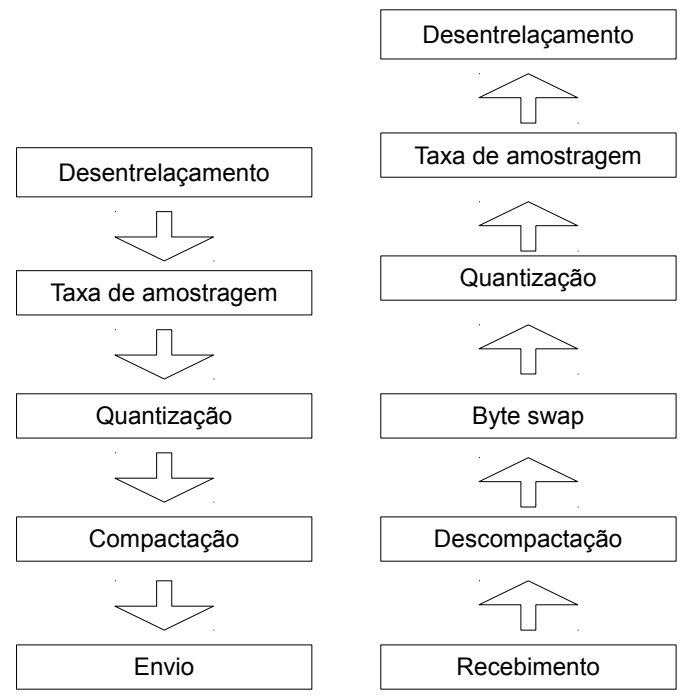

Figura 4.14: Sequência de Processamentos para o Fluxo de Áudio 


\section{Sender}

O medusa_sender implementa sobre um medusa_server o envio de mensagens de dados para o ambiente. Como apresentado anteriormente na discussão arquitetural, há dois tipos de fluxos de dados para o envio, um para áudio e outro para MIDI. A estrutura do medusa_sender foi implementada utilizando a mesma abordagem polimórfica da implementação da camada de rede: várias funções como o empacotamento de dados, a criação de canais e o envio de dados foram definidas como parte da estrutura de dados, cuja definição dependerá do tipo de dado a ser enviado ao ambiente.

$\mathrm{Na}$ instanciação de um medusa_sender, seu nome é informado para o ambiente, e define-se se este sender enviará dados de áudio ou MIDI, após o que é feita a configuração do recurso local. É possível também definir a configuração do recurso de rede; caso esta definição não seja feita o recurso será enviado com o formato local. Ao publicar um recurso, apenas sua configuração de rede será publicada, podendo-se manter a configuração local privada, se desejado. Também é definida na criação de um sender a configuração de rede pretendida.

Uma vez configurado, o medusa_sender fornece para a camada de aplicação funções para escrever em seus buffers de envio. Quando a aplicação escreve dados no buffer do sender o dado é transformado para o formato de rede e enviado o mais rapidamente possível.

Para garantir a configuração do recurso de áudio no cliente, para cada cliente conectado o sender envia uma mensagem de configuração de áudio, para que o cliente converta o áudio recebido para o formato correto. Esta mensagem também é enviada caso haja uma alteração no formato de áudio enviado pela rede.

Como o medusa_control, o medusa_sender possui um conjunto de funções callback para informar à aplicação sobre eventos específicos, como perda de pacotes, conexão de novos clientes ou recebimento de mensagens.

\section{Receiver}

O medusa_receiver implementa o recebimento de mensagens de dados do ambiente, utilizando uma conexão via medusa_client. Como o medusa_sender, o medusa_receiver possui fluxos de dados separados para recebimento de áudio ou MIDI.

A instanciação do medusa_receiver depende da configuração de seu nome no ambiente e também da configuração local do recurso, já que a configuração do recurso de rede é feita via mensagem do medusa_sender no momento da conexão.

A conexão de um medusa_receiver pode ser feita pelo endereço do server ou por meio do nome do recurso. No caso da configuração por nome, o receiver irá pedir a seu medusa_control a configuração de rede do nó correspondente a este nome.

Ao contrário do medusa_sender, que disponibiliza para a rede as mensagens de dados o mais rapidamente possível, o medusa_client pode configurar uma latência proposital entre o recebimento de uma mensagem e sua disponibilização para a aplicação. Esta latência proposital, apesar de nem sempre ser desejada, pode ajudar a garantir a qualidade do sinal transmitido, pois torna a leitura do buffer menos suscetível ao jitter, garantindo a continuidade dos dados disponibilizados para a camada de aplicação.

O medusa_receiver também é responsável por tratar possíveis falhas de comunicação do ambiente, como perda de pacotes e recebimento de mensagens fora de ordem. O tratamento destas falhas no fluxo de áudio pode ocorrer em dois momentos distintos: no recebimento da mensagem ou no consumo das mensagens pelo conector de som.

No consumo das mensagens do buffer do receiver pelo conector de som, há duas situações possíveis: a) um bloco não foi recebido e o buffer está vazio no momento da leitura e b) muitos blocos foram recebidos e há muito conteúdo no buffer aguardando para ser consumido.

Quando a primeira situação ocorre pela primeira vez, o receiver marca seu estado como buffer vazio, copia o último bloco de áudio e aplica um fade out na cópia; as leituras do buffer vazio a partir desta primeira falha obterão blocos de silêncio. Quando o buffer voltar a possuir dados, é 


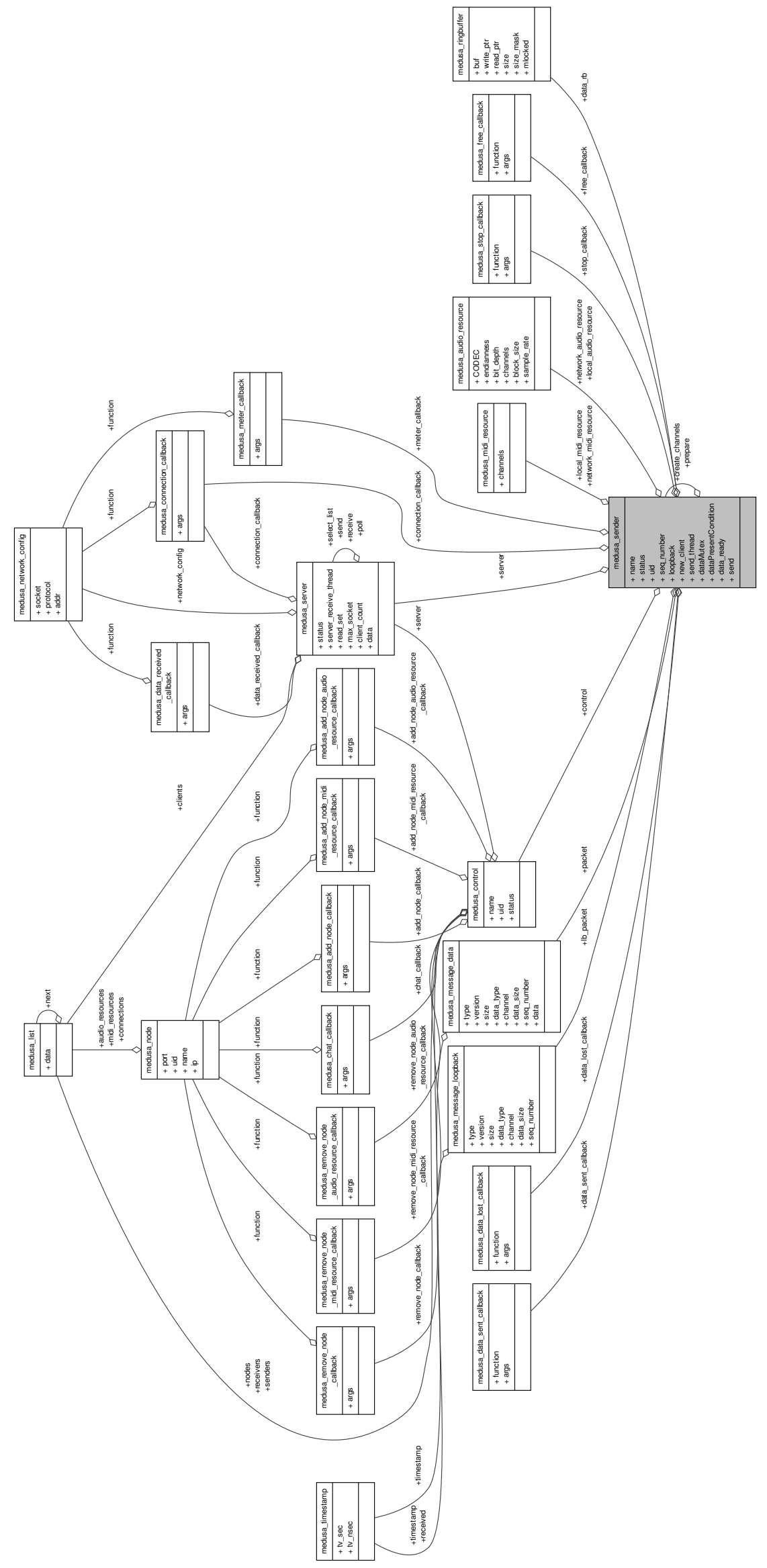

Figura 4.15: Estrutura de Dados do medusa_sender 


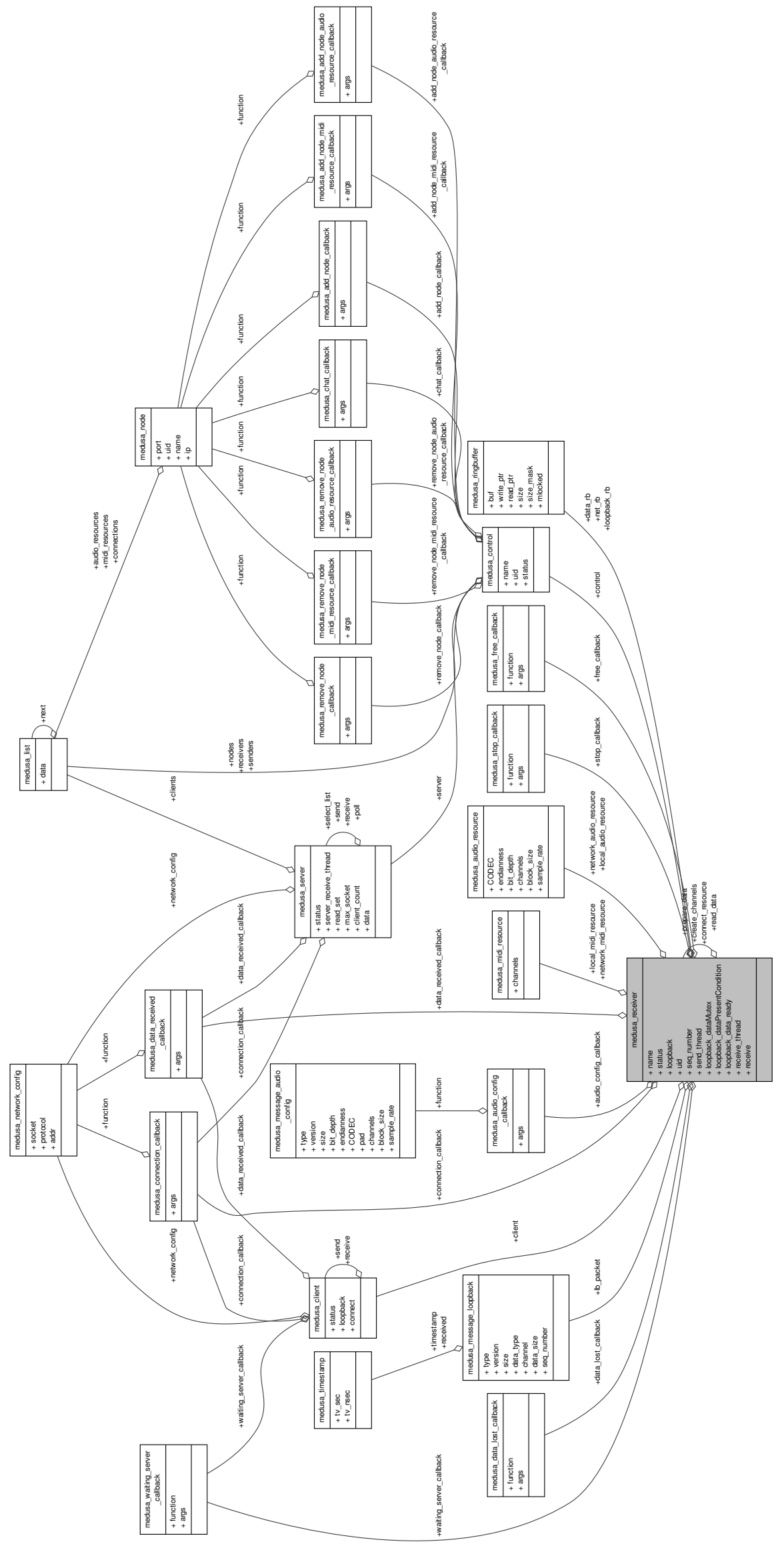

Figura 4.16: Estrutura de Dados do Medusa_receiver 
aplicado um fade in no primeiro bloco de dados, o estado do buffer passa para regular e a partir deste momento a leitura ocorrerá normalmente.

O caso do conteúdo do buffer ser muito maior do que o esperado indica que uma falha de rede pode ter ocorrido ocasionando uma dessincronização entre sender e receiver. Nesta situação, o sender aplica um crossfade entre o primeiro bloco disponível no buffer e o último bloco e elimina os dados excedentes, evitando com isto o consumo de amostras produzidas no passado.

As falhas no recebimento da mensagem podem ser verificadas utilizando para isto o conteúdo das mensagens. As mensagens de dados possuem um número sequencial e por meio deste número é possível precisar se a mensagem recebida está em ordem sequencial, se está adiantada ou atrasada, e também se foi duplicada.

- Se a mensagem estiver em ordem, seu conteúdo é copiado para o buffer destino.

- Se a mensagem estiver duplicada e recebida no tempo certo ela será eliminada.

- Caso a mensagem esteja fora de ordem e adiantada, o receiver verifica se seu estado está marcado como buffer vazio.

- Se o buffer está marcado como vazio, a mensagem é copiada para o buffer destino sem ação adicional.

- Se o buffer não está vazio o receiver preencherá o buffer com cópias desta mensagem até a posição correspondente a seu número sequencial.

- Se a mensagem estiver atrasada isso pode significar que uma mensagem adiantada foi recebida anteriormente, e neste caso, o espaço desta mensagem no buffer foi preenchido pela repetição da mensagem adiantada, sendo necessário verificar se esta duplicação já foi consumida pelo conector de som;

- caso não tenha sido, a mensagem atrasada sobrescreve a versão anterior.

- Caso a versão anterior já tenha sido consumida pelo conector de som, a mensagem é eliminada.

Com estes mecanismos é possível tentar garantir a continuidade das mensagens de áudio. Vale notar que este procedimento não pode ser utilizado para as mensagens MIDI.

\section{Mensagens}

Conforme proposto na arquitetura, há definições de mensagens diferentes que são enviadas / recebidas por diferentes estruturas em diferentes camadas. Independentemente da camada ou da entidade responsável por enviar ou receber uma mensagem, o envio e recebimento das mensagens passa por um processo de serialização / desserialização que inclui a conversão dos tipos para o formato de rede e o alinhamento das estruturas para garantir a compatibilidade das mensagens entre computadores de arquiteturas diferentes. O diagrama de atividades para estas tarefas é apresentado na Figura 4.17.

Além desta padronização na serialização, assumimos também o padrão de cabeçalho de mensagem onde todas as mensagens Medusa possuem um cabeçalho padrão que contém o tipo da mensagem, a versão da ferramenta e também o tamanho da mensagem. A identificação de uma mensagem se dá pelo seu tipo.

A conexão de um cliente a um servidor na camada de rede depende do envio de uma mensagem "hello" e a desconexão de uma mensagem "bye", apresentadas na Figura 4.18.

Já as mensagens do controle são apresentadas na Figura 4.19 e na Figura 4.20. Tais mensagens servem para informar ao ambiente sobre a presença de um novo nó e também para remover um nó do ambiente. 


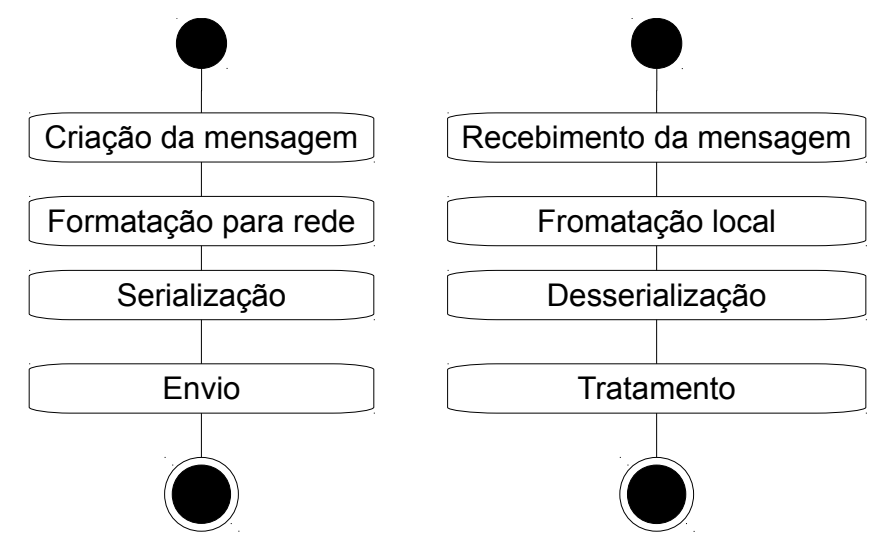

Figura 4.17: Diagrama de Atividades - Enviar / Receber Mensagens

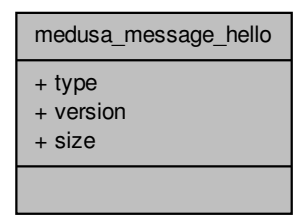

(a) Conexão

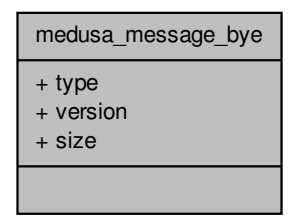

(b) Desconexão

Figura 4.18: Mensagens Utilizadas pela Camada de Rede

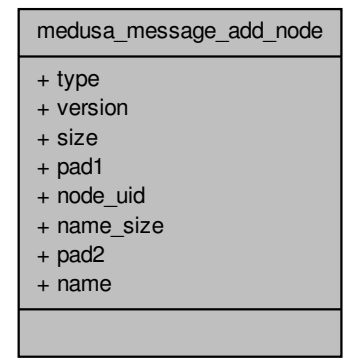

(a) Adicionar Nó

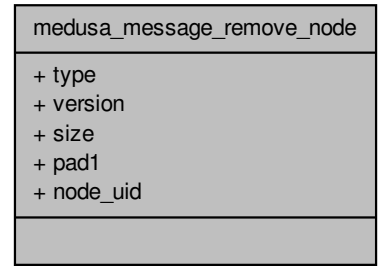

(b) Remover Nó

Figura 4.19: Mensagens Utilizadas pelo medusa_control para Adicionar ou Remover um Nó do Ambiente

O uid destas mensagens representa o uid do medusa_control que está sendo adicionado ao ambiente. Além de adicionar novo nó ao ambiente, as mensagens do medusa_control também adicionam, configuram e removem recursos do ambiente. Neste caso, além do node_uid, estas mensagens contêm a identificação do recurso, que será o uid do sender e/ou receiver responsável por este recurso. A utilização deste identificador único permite que a reconfiguração de um recurso seja feita pela mesma mensagem. Neste caso, é responsabilidade do control verificar se um recurso já existe em sua lista local antes de adicioná-lo pois, caso o recurso exista, ele deve ser apenas atualizado. Para identificarmos se um recurso é um sender ou receiver, utilizamos o campo resource_type, que pode assumir os valores MEDUSA_SENDER ou MEDUSA_RECEIVER.

Já o medusa_sender e medusa_receiver utilizam mensagens para o envio de dados, para configuração de áudio e também uma mensagem de loopback para medições de desempenho no sistema. Tais mensagens são apresentadas na Figura 4.21. Estas mensagens são independentes do tipo de dado que a mensagem carrega, definido pelo campo MEDUSA_DATA_TYPE que pode ser do tipo MEDUSA_AUDIO ou MEDUSA_MIDI. As mensagens de dados contém ainda um número sequencial para permitir o monitoramento de perdas de pacotes e recebimento desordenado. Além destes, 


\begin{tabular}{|l|}
\hline $\begin{array}{c}\text { medusa_message_add } \\
\text { midi_resource }\end{array}$ \\
\hline + type \\
+ version \\
+ size \\
+ resource_type \\
+ pad1 \\
+ channels \\
+ node_uid \\
+ resource_uid \\
+ name_size \\
+ pad2 \\
+ name
\end{tabular}

(a) Adicionar MIDI

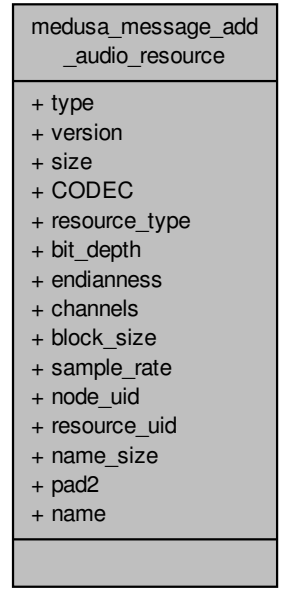

(b) Adicionar Áudio

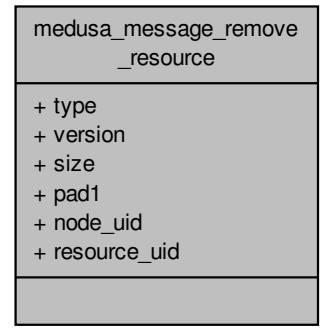

(c) Remover Recurso

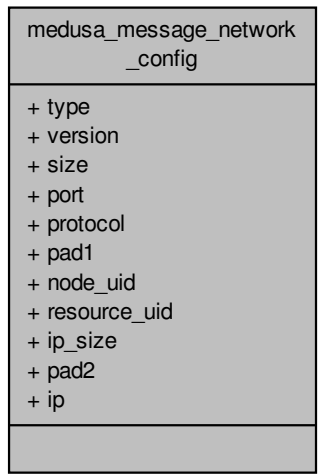

(d) Conf. Recurso(rede)

Figura 4.20: Mensagens Utilizadas pelo Medusa_control para Informar Recursos no Ambiente

a mensagem contém ainda um timestamp que permite analisar o momento de criação do pacote e monitorar o seu tempo de envio e recebimento.

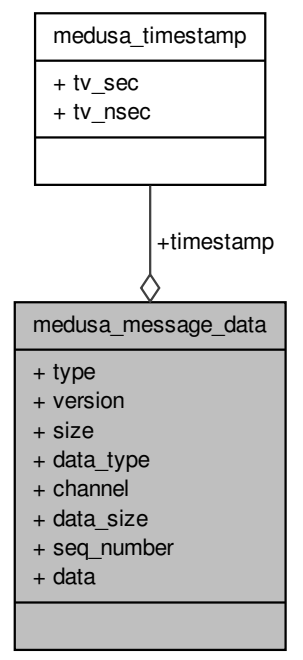

(a) Mensagem de Dados

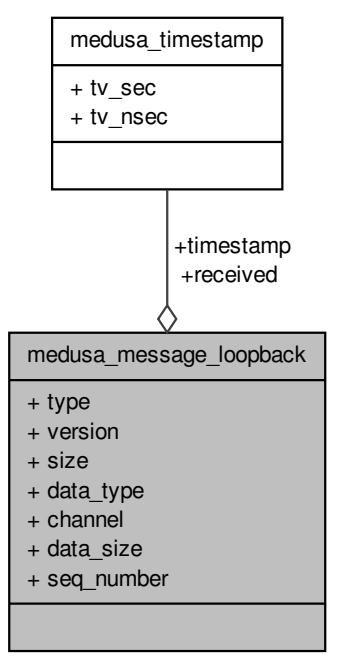

(b) Mensagem de Loopback

\begin{tabular}{|l|}
\hline $\begin{array}{l}\text { medusa_message_audio } \\
\text { _config }\end{array}$ \\
\hline + type \\
+ version \\
+ size \\
+ bit_depth \\
+ endianness \\
+ CODEC \\
+ pad \\
+ channels \\
+ block_size \\
+ sample_rate \\
\hline
\end{tabular}

(c) Mensagem de Conf. de Áudio

Figura 4.21: Mensagens Utilizadas pelo medusa_sender e medusa_receiver para Envio de Dados, Medições de Rede e Configuração de Áudio

Há ainda a definição de mensagens para aplicação, como a mensagem de chat, apresentada na Figura 4.22 .

\subsubsection{Testes}

Teste de Unidade foram desenvolvidos para validar as implementações da libmedusa. Aos testes de Unidade foram adicionados também testes de rede do ambiente que permitem verificar as conexões de rede e o envio e recebimento de mensagens. Tais testes ajudaram no desenvolvimento por tornarem simples a validação do retorno das funções mais críticas do ambiente.

Entre os testes implementados estão: 


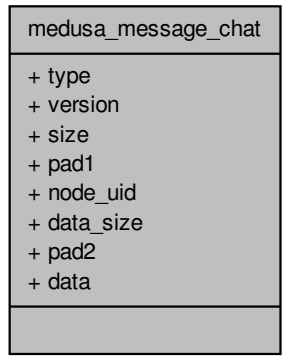

(a) Mensagem de Chat

Figura 4.22: Mensagens Utilizadas por Aplicações

- Testes da camada de rede com o envio, recebimento e loopback com todos os protocolos de transporte e modos de endereçamento.

- Testes da camada de controle quanto à consistência na serialização e desserialização das mensagens do ambiente.

- Teste do medusa_control com adição e remoção e conexão de diversos senders e receivers de áudio e MIDI.

- Testes de sender e receiver com envio e recebimento de áudio e MIDI sem conectores de som.

As aplicações de testes foram executadas com a ferramenta valgrind ${ }^{3}$ utilizando para isto os scripts apresentados no Código 4.3.

$1 \%$ valgrind - tool=memcheck - -leak - check=yes ./ aplicacao

$2 \%$ valgrind $-\mathrm{v}$./ aplicacao

Código 4.3: Scripts de Testes com o Valgrind

Esta ferramenta permitiu verificar a alocação e desalocação de memória da ferramenta e o gerenciamento de threads.

\subsection{Camada de Aplicação}

A camada de aplicação da Medusa inclui os conectores de som e as interfaces de usuário. Estes componentes são combinados para a criação de aplicações que se comunicam com o ambiente, monitorando-o ou alterando seu estado. A seguir apresentaremos o desenvolvimento destes componentes e os protótipos de aplicações desenvolvidos que utilizam a libmedusa, a biblioteca de componentes de componentes gráficos e textuais e os conectores de som.

\subsubsection{Interface de Usuário}

Para auxiliar o desenvolvimento de aplicações foi desenvolvida uma biblioteca de componentes gráficos e textuais que permitem a representação das entidades do sistema para o usuário. Estas entidades dividem-se em entidades locais, como Control, Sender e Receiver, e entidades remotas, como Nó, Recurso de áudio e Recurso MIDI. A Figura 4.23 mostra a representação de um recurso de áudio do ambiente utilizando os componentes de interfaces de usuário.

Além de representar o ambiente, estes componentes permitem também interagir com o ambiente, por exemplo, por meio do envio de mensagens de Chat, conforme apresentado na Figura 4.24.

\footnotetext{
${ }^{3}$ http://valgrind.org/ Acessada em 01/12/2013.
} 


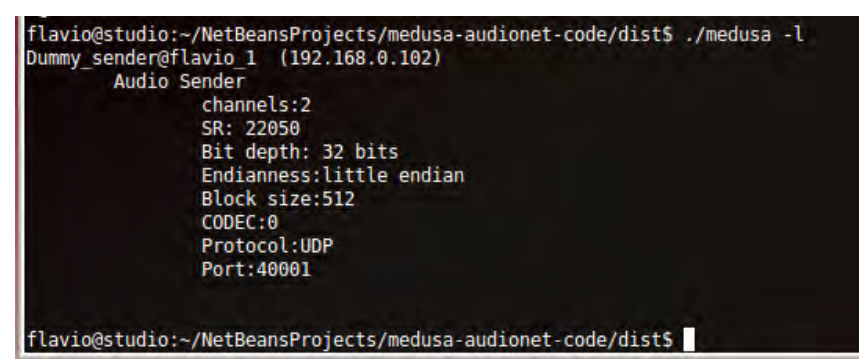

(a) Interface Texto para Recurso de Áudio

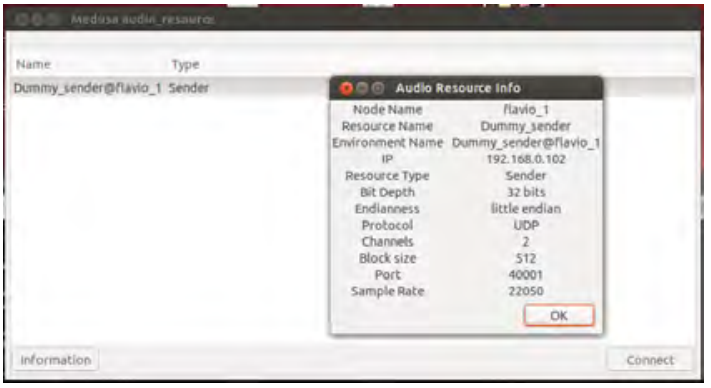

(b) Interface Gráfica para Recurso de Áudio

Figura 4.23: Representação das Entidades do Ambiente

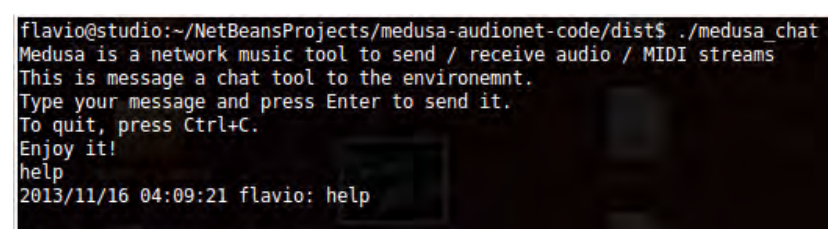

(a) Interface Texto para Chat

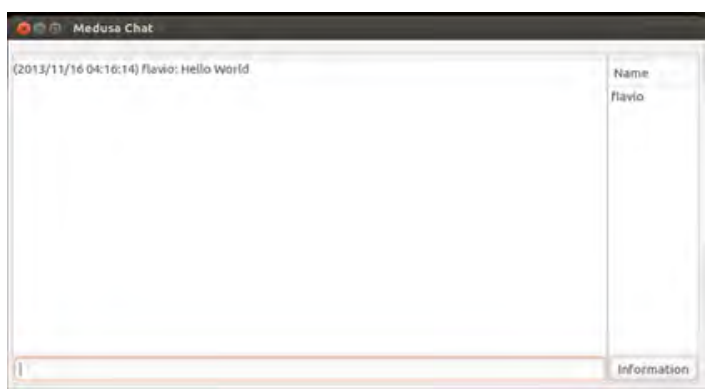

(b) Interface Gráfica para Chat

Figura 4.24: Ferramentas para Chat

Os componentes textuais permitem a configuração de um novo recurso por meio da passagem de parâmetros para a aplicação. Já os componentes gráficos permitem esta configuração expondo os parâmetros ao usuário, conforme apresentado na Figura 4.25.

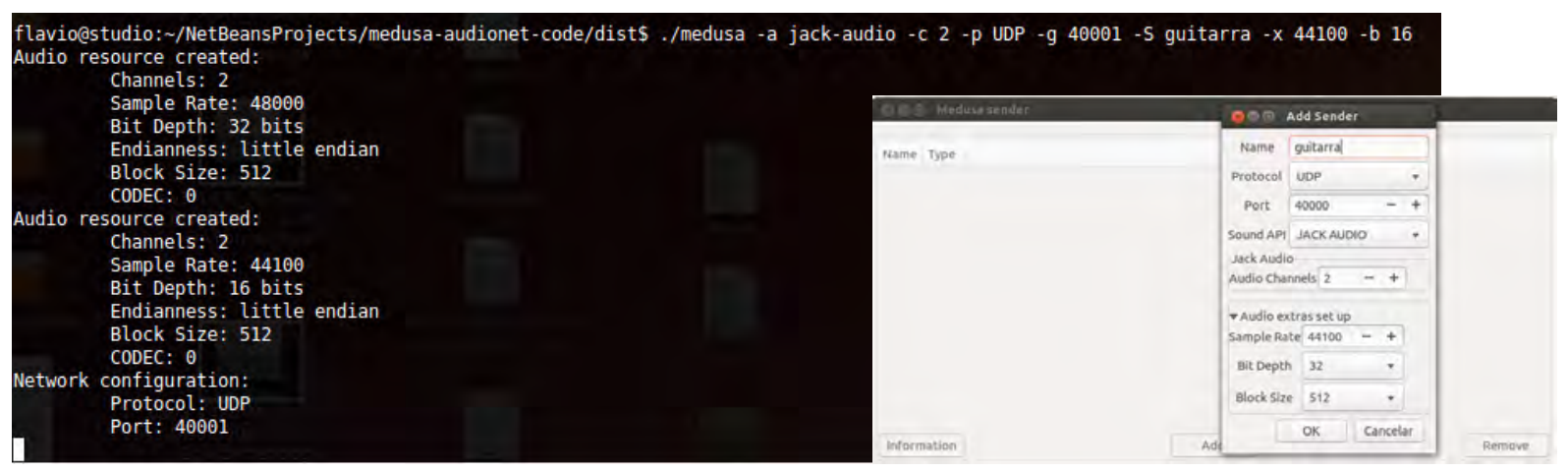

(a) Adicionando Sender com Interface Texto

(b) Adicionando Sender com Interface Gráfica

Figura 4.25: Adição de Sender ao Ambiente

Utilizando as funções callback definidas no ambiente, é possível definir componentes gráficos independentes que trocam informações entre si por meio da libmedusa. Este baixo acoplamento dos componentes gráficos permite que diferentes aplicações sejam desenvolvidas utilizando esta biblioteca.

\subsubsection{Conectores de Som}

Os conectores de som do ambiente possuem a tarefa de integrar a Medusa com APIs de áudio e MIDI para o envio e recebimento. Foram desenvolvidos conectores de som para a Medusa utilizando 
ALSA audio, ALSA MIDI, PortAudio, PortMIDI, JACK Audio, JACK Midi, LADSPA, LV2 e externals para o Pure Data. A Figura 4.26 traz uma visão dos conectores de som escolhidos para a implementação dos protótipos. Além destes conectores, foi desenvolvido um conector de áudio que envia ruído branco e um conector MIDI que envia uma mensagem MIDI fixa para permitir os testes do ambiente sem a utilização de APIs de som.

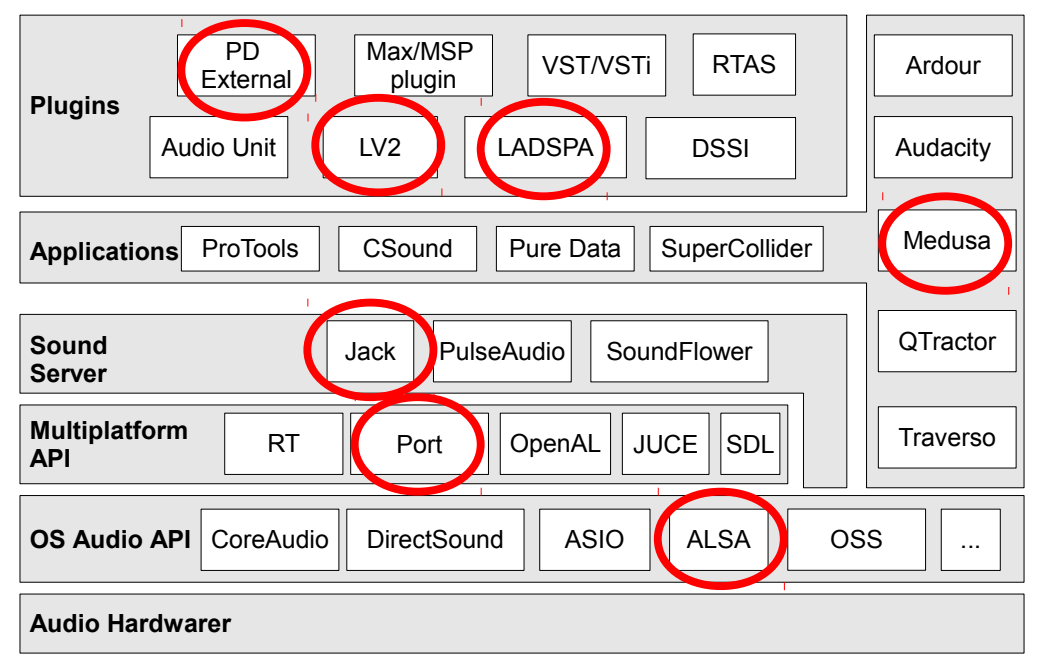

Figura 4.26: APIs Utilizadas para a Implementações da Medusa

As APIs das camadas inferiores desta arquitetura (JACK áudio, JACK MIDI, ALSA áudio, ALSA MIDI, Portaudio e PortMIDI) não possuem em sua definição interfaces para o usuário. Tais conectores foram implementados na forma de uma biblioteca, chamada libmedusa-modules, para permitir a integração dos conectores com as bibliotecas de interface na criação de aplicações.

Além de integrar a Medusa com as APIs de som, os conectores possuem também a tarefa de resolver diferenças entre a quantidade de canais no recebimento e a quantidade de canais disponíveis localmente para a reprodução. Isto pode ocorrer de duas maneiras: a) a quantidade de canais recebido é maior que a quantidade de canais disponíveis no conector, b) a quantidade de canais recebido é menor que a quantidade de canais disponíveis localmente.

Para a primeira situação, é possível tomar duas decisões: escolher quais canais tocar localmente ou mixar os canais recebidos nos canais disponíveis. Na segunda situação, onde recebemos menos canais que os disponíveis localmente, temos duas possíveis soluções. A primeira solução é tocar apenas a quantidade de canais recebidos, o que ocasionaria silêncio nos demais canais, e a segunda solução é copiar sequencialmente os canais recebidos de forma circular, reutilizando os fluxos até ocupar todos os canais de recebimento.

As implementações dos conectores de som da ferramenta utilizaram abordagens distintas para solucionar esta heterogeneidade. As APIs que permitem a criação de canais virtuais, como ALSA MIDI, JACK áudio, JACK MIDI e Pure Data, não possuem limitações na quantidades de canais recebidos e permitem que todos os canais recebidos sejam apresentados ao usuário. Já as APIs que possuem limitações, como ALSA Áudio, PortAudio, Portmidi, LV2 e LADSPA, requereram decisões para este problema. Para estas APIs decidiu-se mixar os canais recebidos, caso sejam recebidos mais canais do que os disponíveis, e completar com silêncio os canais excedentes, no caso de recebermos menos canais do que os disponíveis.

Independentemente da API, os conectores desenvolvidos seguem uma sequência de passos apresentada na Figura 4.27 para disponibilizar um recurso ao ambiente.

Após instanciada a aplicação, cabe ao conector de som produzir fluxos de conteúdo musical e enviá-los para a rede, no caso do medusa_sender, ou consumir fluxos de conteúdo musical recebidos da rede, no caso do medusa_receiver. Tais tarefas são feitas por meio das funções de escrita do buffer circular do sender e de leitura do buffer circular do receiver. No caso do sender, após escrever dados em seus buffers é necessário ainda que a aplicação avise o sender que a escrita encerrou e que os dados estão prontos para o envio. 


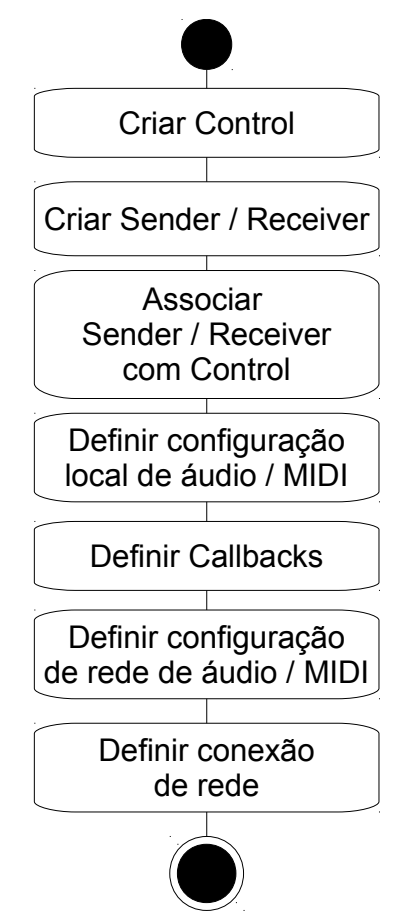

Figura 4.27: Diagrama de Atividades - Criar Aplicação

$\mathrm{Na}$ instanciação de um receiver, os passos para definir a configuração do recurso de rede e a configuração de rede podem ser feitos de maneira transparente utilizando para isto o nome de um recurso no ambiente. Os nomes de recursos no ambiente utilizam a sintaxe recurso@nó. Assim, podemos nos conectar ao recurso "guitarra@flavio", por exemplo, informando apenas este nome.

\subsubsection{Protótipos Desenvolvidos}

Foram desenvolvidos protótipos da Medusa com os conectores de som apresentados anteriormente e também ferramentas de monitoração do ambiente.

\section{Ferramentas para Envio de Conteúdo Musical}

As APIs que dependem de desenvolvimento de interface (JACK Audio, JACK MIDI, ALSA Áudio, ALSA MIDI, PortAudio e PortMIDI) foram unidas em uma única aplicação textual que permite ao usuário escolher qual API utilizar. O Código 4.4 apresenta os parâmetros de configuração desta aplicação.

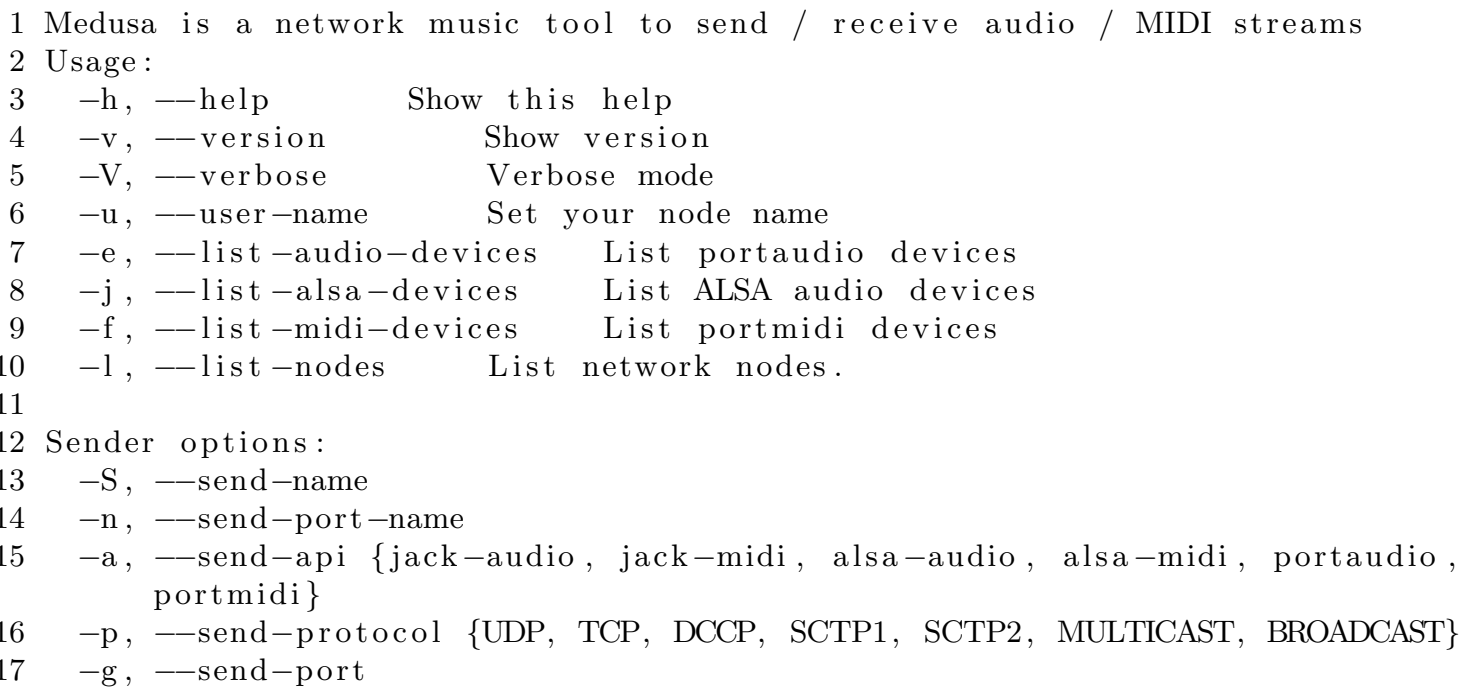




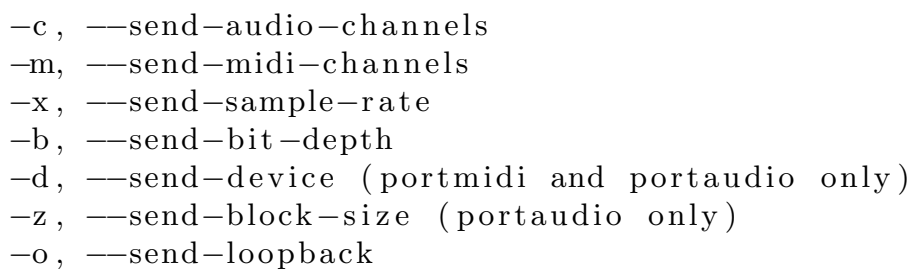

Receiver options:

-r, -receive-from Creates a receiver connected to a sender

$-\mathrm{R},-$ receive - name

$-\mathrm{N},-$ receive-port-name

-A, -receive-api \{jack-audio, jack-midi, alsa-audio, alsa-midi, portaudio, portmidi\}

-P, --receive-protocol \{NONE, UDP, TCP, DCCP, SCTP1, SCTP2, MULTICAST, BROADCAST

$-\mathrm{I},-$ receive -ip

$-\mathrm{G},-$ receive-port

$-\mathrm{C},-$ receive-audio-channels

$-\mathrm{M},-$-receive-midi-channels

$-\mathrm{D},-$-receive-device (portmidi and portaudio only)

$-\mathrm{O},-$-receive - loopback

9 Examples:

0 List nodes:

$41 . /$ medusa $-\mathrm{l}-\mathrm{u}$ Test

42 ./ medusa - - list - nodes $=10$ \#to wait ten seconds for network messages

43 Jack Audio:

$44 . /$ medusa - a jack-audio $-\mathrm{c} \quad 2-\mathrm{x} \quad 44100$-b 16

45 ./medusa -A jack-audio - I 127.0.0.1 - G 40001 -C 2

46 Jack Midi :

$47 \quad$. / medusa - a jack-midi $-\mathrm{m} 2$

48 ./medusa -A jack-midi - I 127.0.0.1 -G 40001 -M 2

49 ./medusa $-\mathrm{A}$ jack - midi $-\mathrm{M} 2-\mathrm{r}$ resource@node

50 ALSA:

$51 \quad . /$ medusa $-\mathrm{j}$

$52 . /$ medusa - a alsa -audio

$53 . /$ medusa -A alsa-audio - I 127.0.0.1 - G 40001

54 ./medusa $-\mathrm{A}$ alsa-audio $-\mathrm{r}$ resource@node

55 ALSA MIDI:

56 ./medusa - a alsa - midi $-\mathrm{m} 2$

57 ./medusa -A alsa-midi - I 127.0.0.1 - G 40001 -M 2

58 ./medusa $-\mathrm{A}$ alsa - midi $-\mathrm{M} 2-\mathrm{r}$ resource@node

59 Portaudio:

60 ./ medusa - - list -audio-devices

$61 . /$ medusa - a portaudio $-\mathrm{d} 2$

$62 . /$ medusa -A portaudio - I 127.0.0.1 - G 40001 -D 6

$63 . /$ medusa -A portaudio -D 6 -r resource@node

64 Portmidi:

$65 . /$ medusa - - list - midi-devices

66 ./medusa - a portmidi -d DEVICE_ID

67 ./medusa -A portmidi - I 127.0.0.1 -G 40001 -D DEVICE_ID

68 Dummy audio: Sends 2 white noise channels

69 ./ medusa - a dummy-audio

70 ./medusa - A dummy-audio - r resource@node

71 Dummy midi: Sends Note on in loop

72 ./ medusa - a dummy-midi

73 ./medusa - A dummy-midi - r resource@node

74 It is possible to define senders and receivers together:

75 ./medusa - a alsa-midi -m 2 -S MEDUSA - p TCP - I 127.0.0.1 - G 40001 -A alsa-midi $-\mathrm{M} 2-\mathrm{P}$ TCP

76 ./medusa - a alsa $-\mathrm{A}$ alsa $-\mathrm{I} \quad 127.0 .0 .1$-G 40001

77 Enjoy it! 
Uma aplicação baseada em interface gráfica, apresentada na Figura 4.28 foi desenvolvida para as APIs que dependem de desenvolvimento de interface deixando novamente para o usuário a possibilidade da escolha entre qual API utilizar.

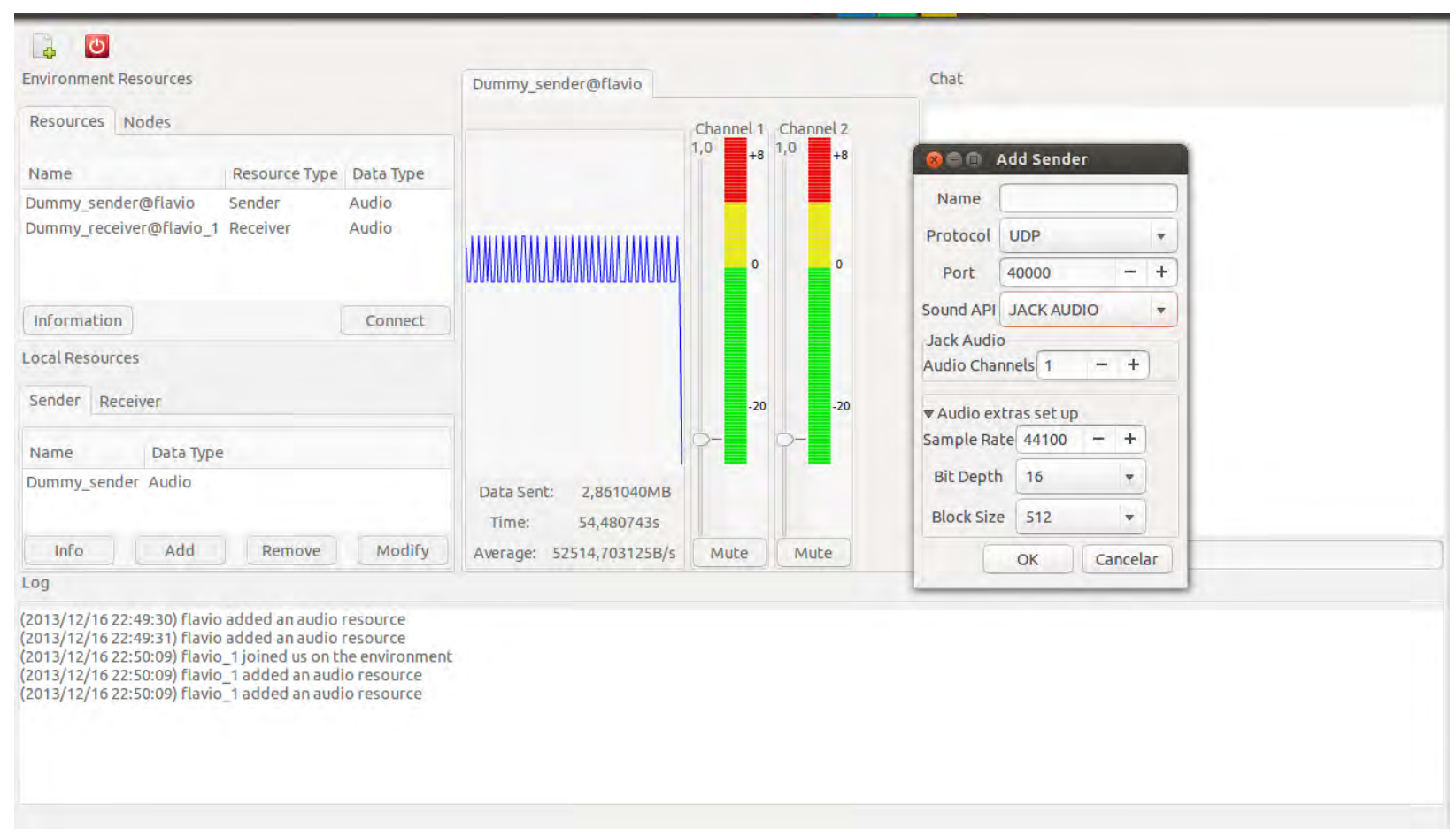

Figura 4.28: Implementação da Medusa em GTK

A Figura 4.29 apresenta os protótipos desenvolvidos com APIs de plugin LV2 e LADSPA da Medusa na ferramenta Ardour e no ambiente Pure Data.

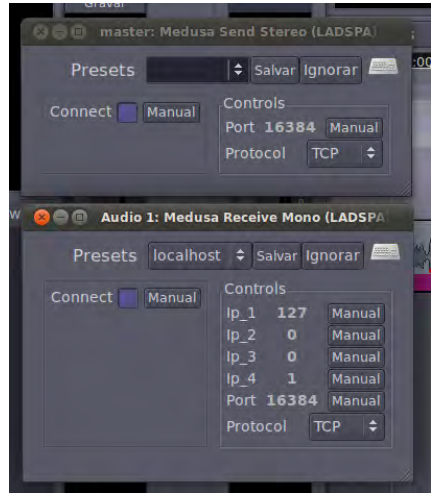

(a) Implementação LADSPA

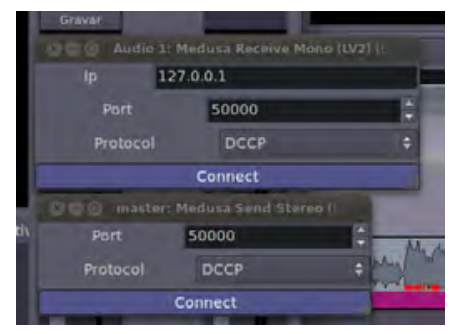

(b) Implementação LV2

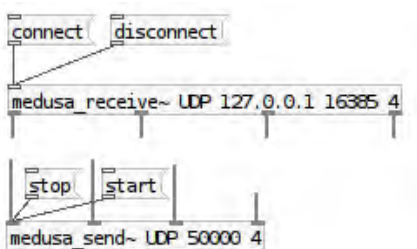

(c) Implementação para o Pure Data

Figura 4.29: Integração da Medusa com o Pure Data e com o Ardour

\section{Ferramentas de Replicação}

A replicação de um recurso pode aumentar a sua disponibilidade na rede por permitir mais de um caminho para um mesmo fluxo de informação. Além disto, utilizar um nó na rede que replica todos os dados do ambiente permite configurar o ambiente em uma topologia estrela, conforme apresentado na Figura 4.30. 


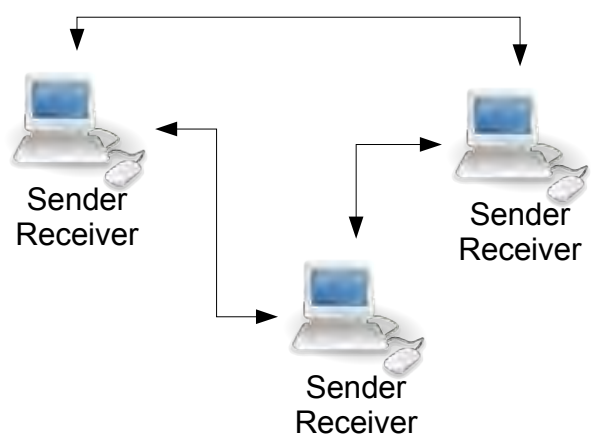

(a) Conexão Peer-to-peer

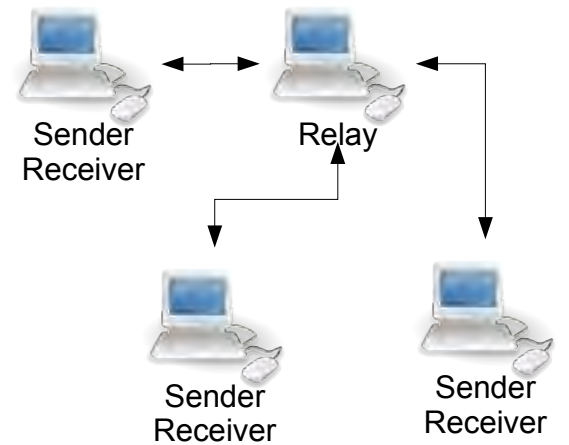

(b) Conexão com Relay

Figura 4.30: Possibilidades de Conexão

Foi desenvolvido um protótipo de servidor de relay que permite a utilização de um nó central na rede. Tal protótipo monitora o ambiente e se conecta automaticamente a todos os recursos disponibilizados no ambiente, replicando-os localmente. Isto permite, por exemplo, que computadores com menor capacidade de processamento, e que poderiam ter dificuldades no gerenciamento de vários clientes, utilizem um replicador para distribuir seus recursos.

Este protótipo funciona tanto replicando os recursos individualmente, quanto mixando todos os recursos recebidos em um único recurso. Com esta segunda possibilidade, este replicador pode ser utilizado também para diminuir o tráfego de rede, diminuindo a quantidade de conexões necessárias para distribuir este conteúdo a todos os nós do ambiente.

Este protótipo foi desenvolvido apenas com interface texto.

\section{Ferramentas de Monitoramento}

Além das ferramentas para o envio de áudio e MIDI, foram desenvolvidas ferramentas para o monitoramento do ambiente, como as ferramentas de Chat, apresentadas anteriormente na Figura 4.24 e ferramentas de $\log$ de mensagens do ambiente, apresentadas na Figura 4.31.

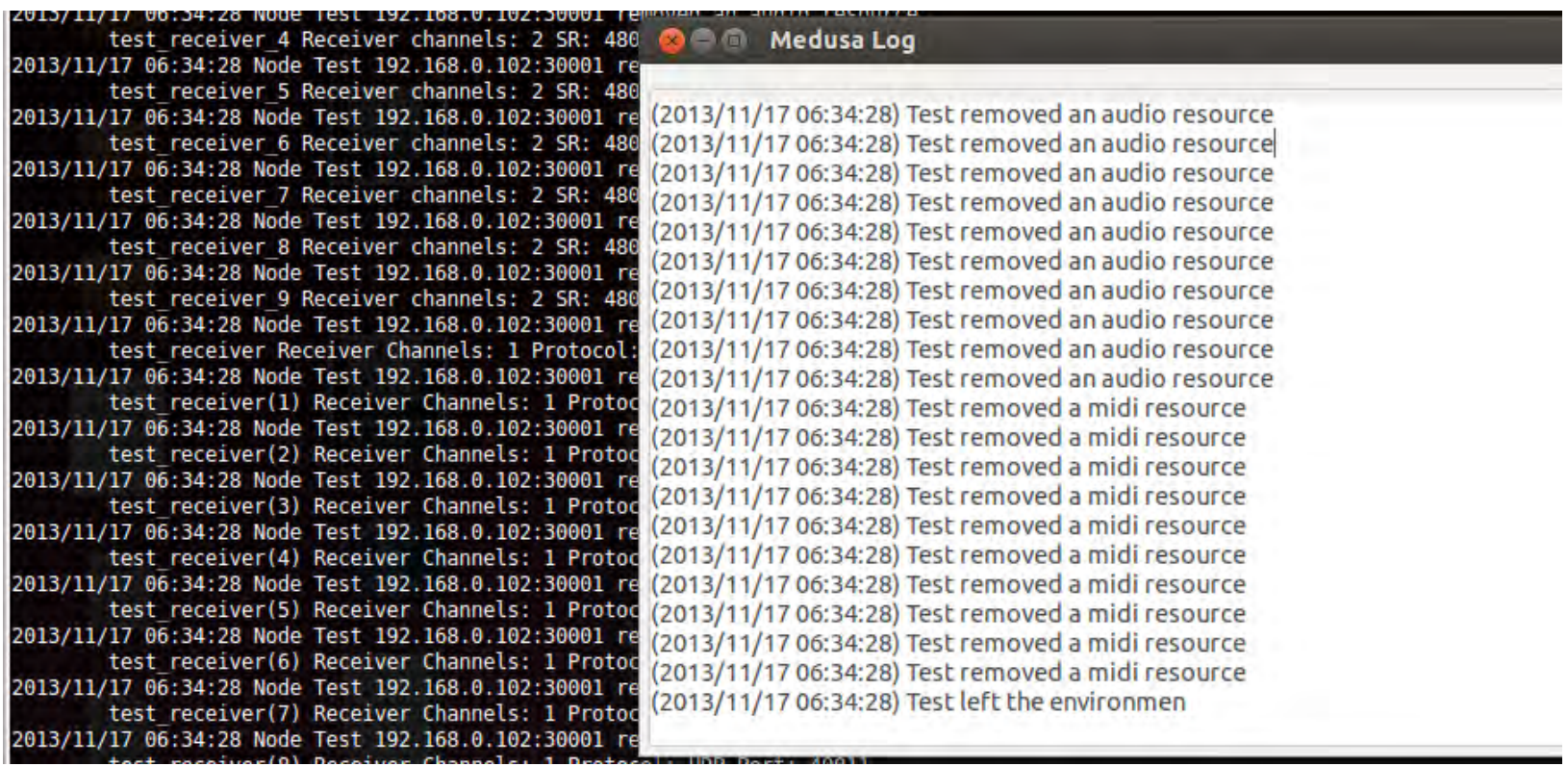

Figura 4.31: Ferramentas de Log com Interface Texto e Gráfica

O próximo Capítulo apresenta avaliações experimentais de alguns aspectos da ferramenta e dos conectores implementados. 


\section{Capítulo 5}

\section{Avaliação e Resultados}

Esta Seção traz resultados e considerações sobre a implementação da Medusa. A implementação das aplicações da Medusa serviram como prova de conceito para a biblioteca e ajudaram a mitigar possíveis falhas no desenvolvimento das ferramentas.

Além de testes e avaliação dos protótipos das aplicações foram realizadas também avaliações quanto aos protocolos de transporte implementados na camada de rede da biblioteca. Tais testes e avaliações ajudaram na escolha das implementações que serão disponibilizadas na versão final da ferramenta.

Este Capítulo traz também os resultados do desenvolvimento da ferramenta Medusa e uma comparação destes com os objetivos do trabalho e o mapeamento inicial de requisitos.

\subsection{Avaliação de Protocolos de Transporte}

A opção por implementar a camada de rede da Medusa sobre vários protocolos de transporte apoiava-se na intenção de compará-los para apresentar ao usuário as possibilidades e limitações de cada protocolo em relação a diversos cenários potenciais de aplicação. Como dito anteriormente, os protocolos implementados e comparados nesta Seção são o UDP, TCP, DCCP e duas formas do SCTP, usando sockets um-para-um e um-para-muitos, aqui indicados por SCTP 1 e SCTP 2.

Para isto, uma aplicação multicanal utilizando a API JACK como conector de áudio foi desenvolvida. Esta aplicação não possui API de áudio e não olha o conteúdo de áudio dos pacotes, limitando-se a enviar (através de um medusa_sender) pacotes de dados para uma outra máquina na rede, e recebê-los de volta para obter estatísticas da transmissão.

Os meta-dados do pacote de dados da Medusa foram utilizados para medir os valores de latência (utilizando o timestamp), perda de pacotes (utilizando o número sequencial) e a quantidade de dados transmitida (utilizando o data size). O cálculo de latência por pacote foi simplificado por estarmos usando apenas o relógio da máquina onde o sender foi instanciado; devido a esta configuração, todos os resultados aqui apresentados são calculados entre envio e recebimento (RTT - Round Trip Time). Além destas métricas, valores de jitter também foram obtidos indiretamente, a partir das medidas de latência.

\subsubsection{Ambiente de Medição}

Para os testes foram utilizados um HP Notebook Pavilion DV6 ${ }^{1}$ (Computador A) para envio e recebimento de dados e um netbook ASUS Eee PC Seashell Series ${ }^{2}$ (Computador B) como a máquina para loopback, ambos com o sistema operacional Ubuntu Linux 12.04. As máquinas foram configuradas com prioridade de tempo real com os parâmetros rtpio $=99$ e nice $=-19^{3}$.

\footnotetext{
${ }^{1}$ Intel(R) Core(TM)2 Duo CPU T6600 2.20 GHz, 4 GB Mem RAM

${ }^{2}$ AMD Athlon(tm) II Neo K125 Processor 1.7 GHz, 2 GB Mem RAM

${ }^{3}$ Configurados no arquivo/etc/security/limits.d/audio.conf
} 
O desempenho foi medido em diferentes conexões físicas, tais como rede local (localhost), cabo crossover, switch, wireless direta e wireless por meio de um access point (AP). Em todas as configurações, com exceção da conexão localhost, o computador A estava enviando, recebendo e calculando o resultado enquanto o computador B meramente funcionava como loopback. No cenário localhost o teste foi realizado em ambas as máquinas.

Em todos os testes o JACK foi configurado com taxa de amostragem de $48 \mathrm{kHz}$, amostras de 32 bits e janelas de 512 amostras. Para o envio o áudio foi reamostrado com qualidade de CD (44.1 kHz, 16 bits). Isto representa uma largura de banda de $\sim 689 \mathrm{Kbps}$ de dados para cada canal transmitido e um pacote com 940 Bytes por bloco processado por canal. Os testes foram executados com 10000 blocos de áudio por canal ou 106.6 segundos.

A latência foi calculada como a média dos valores de RTT de todos os pacotes (1) e o jitter como o desvio absoluto médio dos valores de latência (2):

$$
\begin{aligned}
& \text { Latency }(\Delta t)=\frac{1}{n} \sum_{i=1}^{n} t(i) ; \\
& \text { jitter }=\frac{1}{n} \sum_{i=1}^{n}|t(i)-\Delta t| .
\end{aligned}
$$

Apresentaremos os resultados das medições, seguidos de uma análise dos dados e uma discussão sobre os resultados alcançados.

\subsubsection{Testes de Desempenho}

Como já mencionado, os testes de desempenho foram feitos em 5 conexões físicas diferentes (localhost, cabo crossover, switch, Wi-Fi direta e Wi-Fi com access point), e serão detalhados a seguir.

\section{Localhost}

O primeiro teste foi realizado utilizando uma conexão em localhost, que é uma interface de rede virtual, apresentada pelo endereço especial de IP 127.0.0.1 e utilizada para gerenciamento do sistema. O teste preliminar utilizando localhost apresenta a latência do sistema independentemente do atraso da rede. Isto representa o tempo que o sistema utiliza para empacotar o dado de áudio, fragmentá-lo, copiar para o espaço do kernel, copiar de volta para o espaço de usuário e finalmente desempacotar o dado.

O tempo de copiar o dado a partir da API de áudio (neste teste, o JACK) e de reamostrar o áudio foi ignorado nestas medições, considerando-se que este tempo seria tomado não pela ferramenta de transmissão mas pelo próprio processamento do bloco de amostras no JACK.

A Tabela 5.1 apresenta as medições realizadas em localhost. Todos os tempos estão em milissegundos. Não houve perda de pacotes com nenhum protocolo nesta conexão.

\section{Cabo Crossover}

O crossover é um cabo de rede especial com uma inversão nos fios de transmissão e recepção, para a conexão direta entre dois computadores sem a intervenção de outros dispositivos de rede como hubs, roteadores ou switches, sendo portanto uma maneira bastante eficiente de conectar diretamente dois computadores.

A Tabela 5.2 apresenta as medições (em milissegundos) nesta conexão. Como em localhost, nenhum pacote foi perdido nesta configuração. 
Tabela 5.1: Tempos (em ms) para a Conexão Localhost

\begin{tabular}{|c|c|c|c|c|}
\hline & \multicolumn{2}{|c|}{1 canal } & \multicolumn{2}{|c|}{2 canais } \\
\hline Protocolo & Latência & Jitter & Latência & Jitter \\
\hline \multicolumn{5}{|c|}{ Computador A } \\
\hline UDP & 0.13 & 0.08 & 0.20 & 0.09 \\
\hline TCP & 0.15 & 0.09 & 0.22 & 0.10 \\
\hline DCCP & 0.19 & 0.14 & 0.23 & 0.13 \\
\hline SCTP 1 & 0.19 & 0.09 & 0.31 & 0.10 \\
\hline SCTP 2 & 0.21 & 0.09 & 0.35 & 0.13 \\
\hline \multicolumn{5}{|c|}{ Computador B } \\
\hline UDP & 0.30 & 0.19 & 0.50 & 0.20 \\
\hline TCP & 0.31 & 0.14 & 0.54 & 0.23 \\
\hline DCCP & 0.31 & 0.14 & 0.53 & 0.17 \\
\hline SCTP 1 & 0.40 & 0.20 & 0.60 & 0.13 \\
\hline SCTP 2 & 0.38 & 0.11 & 0.69 & 0.21 \\
\hline
\end{tabular}

Tabela 5.2: Tempos (em ms) para a Conexão Crossover

\begin{tabular}{l|cc|cc}
\hline & \multicolumn{2}{|c|}{ 1 canal } & \multicolumn{2}{c}{2 canais } \\
\hline Protocolo & Latência & Jitter & Latência & Jitter \\
\hline UDP & 0.54 & 0.13 & 0.62 & 0.15 \\
TCP & 0.58 & 0.14 & 0.69 & 0.15 \\
DCCP & 0.58 & 0.14 & 0.67 & 0.18 \\
SCTP 1 & 0.65 & 0.17 & 0.77 & 0.20 \\
SCTP 2 & 0.66 & 0.17 & 0.78 & 0.21 \\
\hline
\end{tabular}

\section{Switch}

Neste cenário de conexão, um switch D-Link DIR-615 e cabos padrão CAT.5e foram utilizados para conectar os computadores. Os resultados para esta conexão estão apresentados na Tabela 5.3. Novamente, nenhum pacote foi perdido.

Tabela 5.3: Tempos (em ms) para a Conexão Switch

\begin{tabular}{l|cc|cc}
\hline & \multicolumn{2}{|c|}{ 1 canal } & \multicolumn{2}{c}{2 canais } \\
\hline Protocolo & Latência & Jitter & Latência & Jitter \\
\hline UDP & 0.72 & 0.13 & 0.81 & 0.15 \\
TCP & 0.73 & 0.15 & 0.93 & 0.16 \\
DCCP & 0.75 & 0.13 & 0.85 & 0.17 \\
SCTP 1 & 0.82 & 0.15 & 0.94 & 0.17 \\
SCTP 2 & 0.82 & 0.14 & 0.98 & 0.20 \\
\hline
\end{tabular}

\section{Wireless Direto}

Para a conexão Wireless direta, foi criada uma rede sem fio padrão 802.11 G no computador A e o computador B foi conectado diretamente a esta rede, sem qualquer outro dispositivo de rede para intermediar esta conexão. O padrão $802.11 \mathrm{G}$ tem um limite de transmissão teórico de 54 Mbps. O resultado destas medições são apresentados na Tabela 5.4. A perda de pacotes é apresentada em números absolutos (de pacotes) e percentuais em relação ao total de pacotes transmitidos (10000 com 1 canal e 20000 com 2 canais). 
Tabela 5.4: Tempos (em ms) e Perda de Pacotes para a Conexão Wireless Direta

\begin{tabular}{l|ccc}
\hline Protocolo & Latência & Jitter & Perda de pacotes \\
\hline \multicolumn{4}{|c}{ canal } \\
\hline UDP & 16.76 & 27.30 & $17(0.17 \%)$ \\
TCP & 20.12 & 33.41 & $1(0.01 \%)$ \\
DCCP & 3.41 & 1.90 & 0 \\
SCTP 1 & 21.00 & 34.85 & 0 \\
SCTP 2 & 20.94 & 35.11 & 0 \\
\hline \multicolumn{4}{|c}{ 2 canais } \\
\hline UDP & 20.10 & 32.08 & $30(0.15 \%)$ \\
TCP & 31.21 & 51.29 & $1(0.005 \%)$ \\
DCCP & 5.02 & 3.16 & $140(0.7 \%)$ \\
SCTP 1 & 27.09 & 44.40 & 0 \\
SCTP 2 & 26.22 & 42.40 & 0 \\
\hline
\end{tabular}

\section{Wireless com Access Point}

O último cenário testado é uma conexão Wi-Fi doméstica, onde um roteador D-Link DSL 2640T foi utilizado como Access Point para os dois computadores. O resultado está apresentado na Tabela 5.5 .

Tabela 5.5: Tempos (em ms) e Perda de Pacotes para a Conexão Wireless com Access Point

\begin{tabular}{lcrc}
\hline Protocolo & Latência & Jitter & Perda de pacotes \\
\hline \multicolumn{3}{c}{ 1 canal } \\
\hline UDP & 14.73 & 17.67 & $137(1.37 \%)$ \\
TCP & 16.76 & 20.52 & 0 \\
DCCP & 15.65 & 18.58 & $552(5.52 \%)$ \\
SCTP 1 & 26.39 & 35.64 & 0 \\
SCTP 2 & 26.56 & 37.33 & 0 \\
\hline \multicolumn{4}{c}{ 2 canais } \\
\hline UDP & 19.99 & 24.48 & $324(1.62 \%)$ \\
TCP & 19.88 & 22.48 & $31(0.155 \%)$ \\
DCCP & 14.70 & 13.26 & $1413(7.065 \%)$ \\
SCTP 1 & 67.49 & 106.79 & 0 \\
SCTP 2 & 72.06 & 166.49 & 0 \\
\hline
\end{tabular}

\subsubsection{Análise Preliminar dos Dados}

Os dados apresentados podem ser organizados em dois diagramas para termos uma visão mais clara do desempenho de cada protocolo. A Figura 5.1 apresenta a latência e a Figura 5.2 apresenta a perda de pacotes para cada protocolo utilizando 2 canais de áudio.

Considerando todas as conexões (incluindo localhost), na Figura 5.1 podemos notar que o protocolo UDP apresenta a menor latência em 4 das 6 conexões, tendo o protocolo DCCP apresentado a menor latência em conexões Wi-Fi. A latência do TCP variou entre a maior em Wi-Fi direto e a segunda menor quando foi utilizado um Access Point. Ambas as implementações do SCTP apresentaram as maiores latências em 5 das 6 conexões.

O mecanismo de controle de congestionamento presente no DCCP parece ser mais compatível com as regras do protocolo 802.11 e isto permitiu ao DCCP obter o melhor desempenho neste cenário. Quando o canal está ocupado, o DCCP descarta o pacote no envio, falhando na entrega e causando uma perda de pacote; este descarte de dados pode ser visualizado na Figura 5.2. Ao 


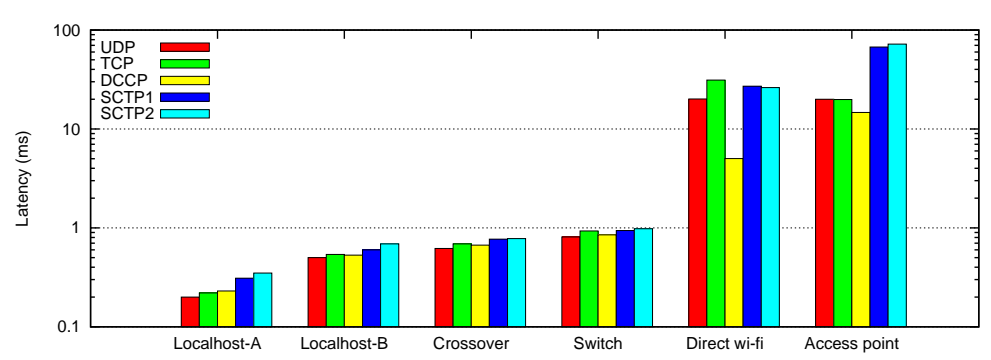

Figura 5.1: Resumo das Medições de Latência - 2 Canais.

descartar mais pacotes, o DCCP conseguiu ser mais rápido que o UDP no envio em Wi-Fi, evitando ao mesmo tempo o congestionamento da rede.

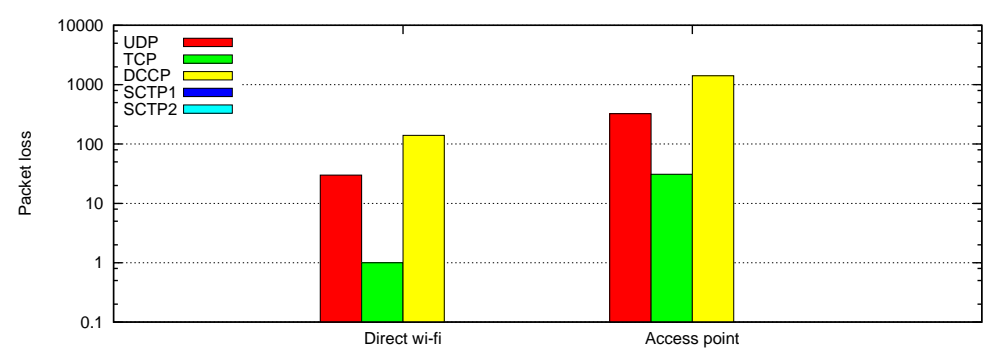

Figura 5.2: Resumo das Medições de Perda de Pacotes - 2 Canais.

Analisando a perda de pacotes apresentada na Figura 5.2, pode-se observar que o SCTP não perdeu pacotes em nenhuma conexão, ao passo que o DCCP, como dito anteriormente, perdeu vários pacotes nas conexões em que ele foi o mais rápido.

Observamos que o TCP também perdeu alguns pacotes na transmissão sem fio. A perda de pacotes no TCP, um protocolo confiável, se dá pelo tempo limite da flag timeout configurada para este protocolo; nestes casos, o dado foi descartado antes do envio.

Um sumário da análise de dados pode ser feito ao dividirmos os protocolos em grupos: UDP e DCCP sendo mais rápidos e menos confiáveis, TCP em um meio termo e o SCTP sendo mais lento e mais confiável. Agrupando-os desta maneira nós obtemos uma avaliação dos protocolos que permite ao usuário escolher entre protocolos mais rápidos ou mais confiáveis de acordo com o cenário de aplicação específico.

\subsubsection{Discussão}

Além das considerações anteriores obtidas diretamente por inspeção dos resultados numéricos, os testes feitos permitem outras observações relacionadas à medição de desempenho na transmissão de fluxos de áudio.

Uma primeira observação derivada de nossos dados pode ser feita em relação à latência em conexão localhost, que pode ser interpretada como a latência intrínseca a uma única máquina. Como o computador B possui menos recursos computacionais devido à sua configuração física (hardware), seus resultados são inferiores aos do computador A, confirmando o fato (esperado) de que a configuração da máquina influencia diretamente no desempenho da transmissão de fluxos de áudio em rede. Como uma comunicação em rede é afetada pela latência intrínseca em ambos os nós, pode-se esperar que em nenhum cenário envolvendo os computadores $\mathrm{A}$ e $\mathrm{B}$ os resultados de latência sejam melhores que os obtidos no computador B em conexão localhost.

Uma segunda observação pode ser feita em relação à comparação entre a conexão com cabo crossover e a conexão através de um switch, que indica claramente o impacto causado pela adição de um dispositivo de rede no caminho de uma conexão. Adicionar outros dispositivos de rede à conexão significa adicionar um conjunto de buffers de envio e recebimento, e significa também introduzir um novo conjunto de políticas de roteamento de pacotes. No caso dos equipamentos utilizados, 
estes buffers e políticas aumentaram a latência em cerca de $0.16 \mathrm{~ms}$ quando comparamos a conexão switch com a conexão com cabo crossover.

Apesar da escolha de protocolo de transporte influenciar no desempenho da comunicação, nossos dados mostram que a camada física é também um fator importante a ser considerado em uma conexão de música em rede. Para todos os protocolos, a latência com Wi-Fi utilizando um AP foi no mínimo 20 vezes maior do que a latência da conexão com cabo crossover, considerando o mesmo protocolo de transporte. Esta diferença enorme de desempenho é explicada na conexão física: enquanto cabos de rede possuem pares de fios diferentes para enviar e receber dados, uma conexão Wi-Fi utiliza o mesmo canal para enviar e receber os dados. Além disto o canal de comunicação é um recurso compartilhado e existem algumas race conditions no acesso a ele. Por esta razão, o protocolo Wi-Fi possui algumas soluções para evitar o congelamento do sistema, incluídas no protocolo da camada física (família 802.11). Isto inclui um mecanismo de controle de congestionamento que evita a sobrecarga do canal por um único remetente, resultando em um ambiente melhor compartilhado.

Como o UDP e o DCCP não possuem mensagens ACK ou recuperação de pacotes perdidos, estes protocolos possuem menos custo (overhead) de comunicação, que corresponde neste caso a uma comunicação com taxas de transferência mais altas porém com mais perdas de pacotes.

Outra observação que estas medições nos permitem fazer se refere às duas implementações do protocolo SCTP. Apesar de suas diferenças conceituais (por exemplo, uma é orientada a mensagens e a outra é orientada a conexão), houve pouca diferença de desempenho entre elas. Por esta análise, concluímos que manter ambas as implementações na versão final da ferramenta torna sua configuração mais complexa e não agrega melhorias significativas ao resultado final. Optamos por preservar as duas versões de implementação na libmedusa, mantendo contudo a implementação SCTP2 apenas no código (e não presente nas interfaces para os usuários).

\subsection{Avaliação dos Conectores MIDI}

Apesar de tratarmos o envio de mensagens MIDI como um fluxo, as mensagens MIDI são esporádicas e orientadas a eventos que são disparados por um usuário ou dispositivo, sendo assim intrinsecamente diferentes das mensagens de áudio, reguladas a partir de uma determinada taxa de amostragem, que implica em uma regularidade temporal na produção dos blocos de áudio.

Pela especificação do protocolo MIDI, um evento deve ser entregue imediatamente, e por esta razão o protocolo MIDI não possui a noção de tempo como dado ou meta-dado a ser transmitido, mas apenas como um suporte para o fluxo MIDI [MID08]. Por outro lado, as APIs MIDI utilizadas na implementação da Medusa possuem informações complementares ao protocolo MIDI, para permitir a sincronização de aplicações distintas. Por esta razão realizamos uma série de testes nos conectores MIDI para verificar o quanto a escolha da API pode influenciar na latência e jitter de eventos MIDI.

Além de uma comparação experimental, apresentaremos uma comparação teórica que pode auxiliar na escolha do conector em função do cenário de aplicação.

\subsubsection{Comparação Teórica Entre APIs MIDI}

Apresentamos a seguir as principais APIs MIDI utilizadas em aplicações musicais profissionais em Linux: ALSA MIDI, PortMidi e JACK MIDI.

\section{ALSA MIDI}

A API ALSA fornece dois tipos de eventos MIDI para o desenvolvimento de uma aplicação: raw e seq. O ALSA raw opera diretamente sobre o driver MIDI, sem o conceito de tempo associado aos eventos. O ALSA seq (sequencer) adiciona às mensagens MIDI o conceito de tempo e também monitora aplicações que estejam em modo de espera (bypass). A implementação da Medusa foi feita utilizando o ALSA seq. 
O ALSA MIDI fornece suporte a dispositivos MIDI USB e PCI. Neste conector, todas as aplicações MIDI são mapeadas como dispositivos virtuais e não há diferenças significativas entre um dispositivo virtual ou físico. Uma vez que a aplicação criou um dispositivo virtual, qualquer dado em suas portas pode ser roteado para outros dispositivos por meio da conexão de portas. Algumas aplicações podem ser utilizadas para gerenciar estas conexões MIDI no ALSA como, por exemplo, o qjackctl ${ }^{4}$.

No ALSA seq, o timestamping de cada evento utiliza um valor inteiro associado a uma unidade denominada tick (uma medida de tempo discreto relacionado com o tempo específico da trilha MIDI). Outra noção de tempo no ALSA seq é a duração absoluta da nota ou evento, medida em segundos e nanossegundos.

\section{PortMidi}

A API PortMidi permite listar os dispositivos MIDI, tanto físicos quanto virtuais, existentes no computador, e apresentar suas portas de entrada e saída. No PortMIDI, um evento MIDI possui uma informação temporal relacionada ao relógio interno do PortMidi.

No Linux, o PortMidi é implementado sobre o ALSA, mas diferentemente do ALSA ele cria um fluxo de dados conectado diretamente à porta de um dispositivo MIDI, sendo que a conexão desta porta não pode ser alterada ou roteada de outra maneira durante a execução da aplicação. Devido à sua implementação sobre o ALSA MIDI, o PortMidi possui acesso apenas a dispositivos MIDI USB e PCI.

\section{JACK MIDI}

Como o ALSA MIDI, o JACK MIDI pode ser utilizado para interconectar aplicações e permitir o redirecionamento de fluxos entre elas. Entretanto, o JACK MIDI não acessa os periféricos gerenciados pelo ALSA, permitindo o uso apenas de hardware com conexões firewire por meio do driver FFADO.

Algumas aplicações, como o a2jmidi / j2amidi ${ }^{5}$, podem servir de ponte entre o JACK MIDI e o ALSA MIDI. Com a ajuda destas aplicações é possível conectar hardware ALSA em aplicações MIDI escritas sobre o JACK.

Quanto à sincronização, virtualmente não há jitter no JACK MIDI pois os eventos MIDI possuem a precisão das amostras de áudio; um evento no JACK MIDI é alinhado com os blocos de áudio e sincronizado com uma determinada amostra dentro deste bloco. Já a latência é fixa e corresponde à diferença do tempo lógico do JACK em relação ao tempo real, que é a duração de um bloco de áudio. Por esta razão, é possível ajustar a latência do sistema ajustando o tamanho do bloco de áudio (em amostras) e a taxa de amostragem do sinal.

\section{Resumo da Comparação Teórica de APIs MIDI}

Apesar do fato das APIs expostas terem abordagens e características diferentes, agrupamos algumas destas características para uma comparação teórica, apresentada resumidamente na Tabela 5.6 .

Indo além da comparação teórica, comparamos o desempenho das implementações da Medusa utilizando estes conectores de som. Com isto, foi possível verificar experimentalmente como a escolha da API pode influenciar na latência final do sistema.

\subsubsection{Ambiente de Medição}

Para medir a latência do sistema um sequenciador MIDI foi utilizado para produzir comandos note-on e note-off. Nós escolhemos a aplicação Qmidiarp ${ }^{6}$ para estes testes, pois este sequenciador

\footnotetext{
${ }^{4}$ http://qjackctl.sourceforge.net/ Acessada em 01/12/2013.

${ }^{5}$ http://home.gna.org/a2jmidid/ Acessada em 01/12/2013.

${ }^{6}$ http://qmidiarp.sourceforge.net/ Acessada em 01/12/2013.
} 
Tabela 5.6: Comparação Teórica das APIs MIDI

\begin{tabular}{lccc}
\hline Característica & ALSA MIDI & PortMidi & JACK \\
\hline Multi-portas & Sim & Não & Sim \\
Multi-plataforma & Não & Sim & Sim \\
Dispositivos virtuais & Sim & Sim & Sim \\
Múltiplos dispositivos & Sim & Não & Sim \\
Múltiplas conexões & Sim & Não & Sim \\
Dispositivos de hardware & PCI / USB & PCI / USB & Firewire \\
\hline
\end{tabular}

MIDI opera sobre ALSA MIDI e JACK MIDI. Assim, não foi necessário adicionar outro software para interfacear entre as APIs distintas.

Foi configurado um laço de teste para $120 \mathrm{bpm}$ tocando duas semínimas por compasso, o que significa um note-on e um note-off por segundo. A duração das notas foi configurada como zero, o que deveria resultar em um evento note-on seguido imediatamente de um evento note-off. $\mathrm{O}$ teste foi feito executando o laço 1300 vezes, com uma duração aproximada de 11 minutos.

As duas instâncias da ferramenta envolvidas nos testes foram executadas na mesma máquina, e conectadas pelo endereço localhost, permitindo assim o uso do mesmo relógio para as comparações temporais. A primeira instância da Medusa estava enviando eventos MIDI gerados pelo Qmidiarp e recebendo de volta da segunda instância pelo canal loopback.

Teoricamente, toda mensagem note-on deveria ser tocada um segundo após a próxima mensagem. O mesmo deveria ocorrer com as mensagens note-off. Nós chamamos este tempo teórico "expected_t(i)" e o instante onde o evento realmente ocorreu de "t(i)". Consideramos todas as medições relativas ao primeiro evento, que por convenção ocorre no instante 0. Como o primeiro evento também sofreu uma latência indeterminada, calculamos a diferença mínima entre o tempo de ocorrência e o tempo teórico correspondente a cada evento, conforme apresentado na Equação 5.3.

$$
\min \_t=\left|\min \left(t(n)-\operatorname{expected} \_t(n)\right)\right|
$$

Calculamos a latência como a média das diferenças entre o tempo relativo tempo esperado do evento, adicionando a latência mínima a todos os valores (Equação 5.4).

$$
\text { latency }(\Delta t)=\frac{1}{n} \sum_{i=1}^{n}\left(t(i)-\text { expected } \_t(i)+\min \_t\right)
$$

O jitter foi calculado como o desvio absoluto médio dos valores de latência (Eqn. 5.5).

$$
\text { jitter }=\frac{1}{n} \sum_{i=1}^{n}|\operatorname{rt}(i)-\Delta t|
$$

Também foi calculado o tempo do evento note-off baseado na diferença média entre o tempo do evento note-on e o do evento note-off (5.6).

$$
\Delta \text { Note_off }=\frac{1}{n} \sum_{i=1}^{n}(\text { note_off }(i)-\operatorname{note} \text { _on }(i))
$$

\subsubsection{Testes de Desempenho}

Nós calculamos a latência do sistema em quatro estágios diferentes:

1. o tempo de transmissão do sender,

2. tempo do receiver adquirir o dado,

3. tempo do receiver consumir o dado e 
4. tempo do sender receber a mensagem loopback,

cujos resultados são apresentados na Tabela 5.7.

Tabela 5.7: Medição de Latência (Tempos em ms)

\begin{tabular}{lcccc}
\hline API & Tempo 1 & Tempo 2 & Tempo 3 & Tempo 4 \\
\hline ALSA MIDI & 0.268 & 0.370 & 0.745 & 3.045 \\
PortMidi & 2.380 & 2.574 & 2.907 & 5.196 \\
JACK MIDI & 3.923 & 4.033 & 14.374 & 14.590 \\
\hline
\end{tabular}

Como a latência variou durante os testes, também calculamos o jitter, apresentado na Tabela 5.8.

Tabela 5.8: Medições de Jitter (Tempos em ms)

\begin{tabular}{lcccc}
\hline API & Tempo 1 & Tempo 2 & Tempo 3 & Tempo 4 \\
\hline ALSA MIDI & 0.284 & 0.295 & 0.674 & 1.939 \\
PortMidi & 0.609 & 0.936 & 0.937 & 2.016 \\
JACK MIDI & 2.749 & 3.950 & 2.748 & 2.759 \\
\hline
\end{tabular}

As médias das diferenças entre note-on e note-off são apresentadas na Tabela 5.9. Esta Tabela também apresenta o jitter e a porcentagem de eventos note-off que ocorreram ao mesmo tempo que o evento note-on.

Tabela 5.9: Tempos de Note-off e Jitter (Tempos em ms)

\begin{tabular}{lccc}
\hline API & note-off & jitter & \% of same time \\
\hline ALSA MIDI & 0.008 & 0.009 & $56 \%$ \\
PortMidi & 0.033 & 0.046 & $49.5 \%$ \\
JACK MIDI & 0.002 & 0.003 & $86 \%$ \\
\hline
\end{tabular}

\subsubsection{Análise dos Dados}

As colunas "Tempo 1" nas Tabelas 5.7 e 5.8 apresentam a latência e o jitter no envio de dados MIDI. Estes dados representam quão precisamente as APIs tocam as notas localmente, e confirmam que o JACK possui a maior latência, porém não confirmam a característica teórica desta API quanto à não existência de jitter. Analisando o código-fonte da ferramenta utilizada, observou-se que o Qmidiarp não utiliza o alinhamento de eventos MIDI com amostras do bloco de áudio, conforme especificado pelo JACK. Repetimos os experimentos com outras ferramentas MIDI que possuem suporte para esta API, como j2a, j2amidi_bridge e Hydrogen, e observamos o mesmo comportamento, devido ao fato de estas ferramentas também não implementarem o alinhamento de eventos com o bloco de áudio.

Outras ferramentas implementadas com o JACK utilizam este servidor apenas para fluxos de áudio, utilizando outras APIs para as conexões MIDI; exemplos destas ferramentas são Pure Data, QTractor, RoseGarden e LMMS. Mesmo que utilizássemos uma destas ferramentas para obter um evento MIDI mais preciso, esta precisão seria perdida na aplicação ponte entre o ALSA MIDI e o JACK MIDI. A única implementação / configuração que apresentou o alinhamento de eventos MIDI corretamente implementado com o JACK foi o driver FFADO com uma interface de som firewire. 

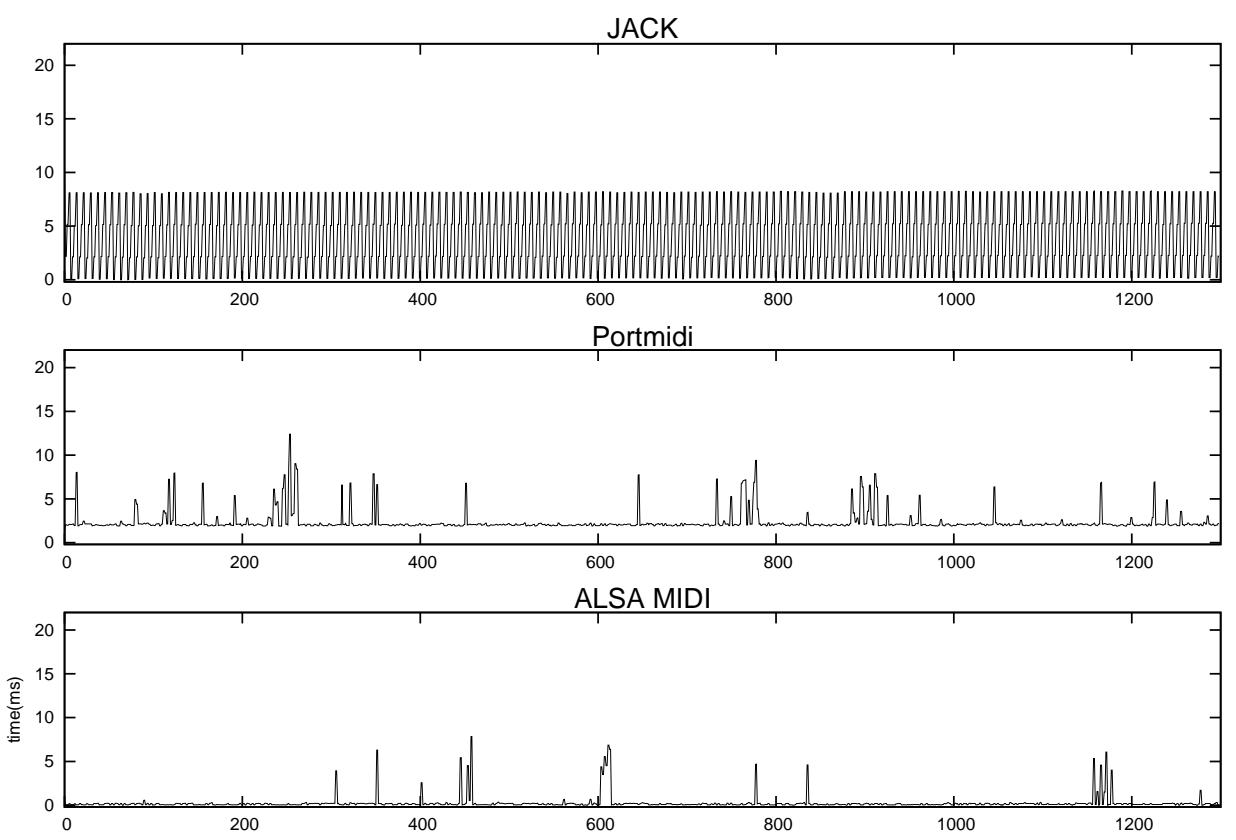

Figura 5.3: Latência de Entrada MIDI (Tempo 1)

O resultado da medição de entrada é apresentado na Figura 5.3. Em nossos experimentos notamos que todos os eventos MIDI no JACK foram alinhados com a primeira amostra do bloco, o que explica a forma de onda dente-de-serra dos valores da latência para esta API. Na Figura 5.3 o pior valor de latência para um evento MIDI foi $7.851 \mathrm{~ms}$ com ALSA MIDI, $10.140 \mathrm{~ms}$ com JACK e 12.390 ms com PortMidi.

Como o PortMidi é implementado em Linux por meio do ALSA MIDI, é previsto que ele não obterá resultados melhores que os obtidos com a API ALSA MIDI. Apesar do ALSA ter obtido os melhores resultados, é válido lembrar que esta implementação não é portável e não está disponível para outros sistemas operacionais.

A segunda coluna, "Tempo 2", apresenta o tempo que a Medusa gastou para enviar o evento do sender para o receiver. Subtraindo o Tempo 1 do Tempo 2, a latência da Medusa está entre $0.1 \mathrm{~ms}$ e $0.2 \mathrm{~ms}$ para todas as APIs. Como os testes foram executados em localhost, este tempo pode ser entendido como o tempo gasto pelo sistema para empacotar o dado MIDI, copiar o dado para o espaço do kernel, copiá-lo de volta para o espaço de usuário e finalmente desempacotá-lo.

A terceira latência medida é o tempo do dado ser tocado no receiver ("Tempo 3"), apresentado na Figura 5.4. Novamente, o desempenho do JACK pode ser entendido como uma implementação simplista desta API. Os eventos MIDI no JACK são sincronizados com a primeira amostra de cada bloco de áudio onde o evento deverá ocorrer, e por esta razão a configuração do tamanho do bloco do JACK influencia na latência dos eventos MIDI. Em nossos testes o JACK foi configurado com taxa de amostragem de $48 \mathrm{kHz}$ e blocos de 512 amostras. Isto significa que cada bloco do JACK possui um tempo de 10.67 ms de duração. Como a Medusa não é implementada como um cliente interno do JACK, o dado recebido deve aguardar o próximo bloco para ser executado, e por esta razão o tempo de duração do bloco é adicionado à latência do sistema. Neste estágio as latências do ALSA MIDI e do PortMidi foram bastante próximas.

A última latência medida, "Tempo 4", é o tempo de loopback. Cada pacote foi enviado com apenas um evento MIDI. O pacote de Loopback remove este dado e adiciona mais 2 timestamps de 64 bits cada. Como o pacote Loopback da Medusa é maior que o pacote de dado, seu tempo de recebimento também é maior. Estes dados mostram que a medição do tempo em RTT para o envio do pacote de dados e o recebimento do pacote loopback não é duas vezes maior que o tempo de envio do pacote de dados.

O tempo de note-off, apresentado na Tabela 5.9, pode ser interpretado como o tempo que a API 


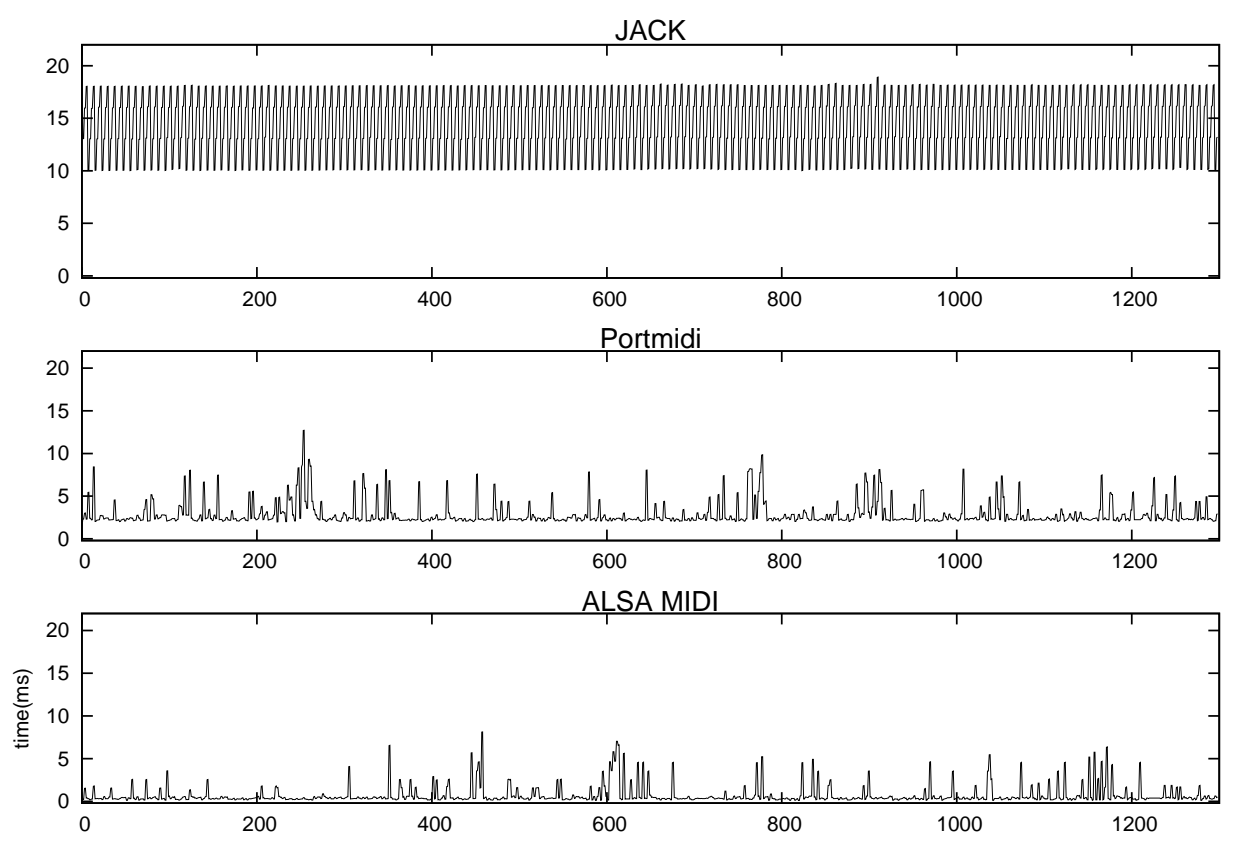

Figura 5.4: Latência da Saída MIDI

leva para responder a dois eventos MIDI que ocorreram ao mesmo tempo. Sabendo que a aplicação foi programada para enviar o note-on e o note-off ao mesmo tempo, a maneira como a aplicação lê estes eventos mostra a precisão na sincronização destes eventos. Como o JACK alinha ambos os eventos com a mesma amostra, ele sempre será mais preciso que as alternativas, no caso de eventos que ocorrem simultaneamente (por exemplo, acordes).

\subsubsection{Discussão}

A possibilidade de criação de portas virtuais e conexão entre estas portas nos conectores JACK MIDI e ALSA MIDI tornam estas APIs mais flexíveis para usuários experientes e menos intuitivas para usuários leigos. A possibilidade de listar os dispositivos presentes no computador e realizar uma conexão direta com o dispositivo físico torna o PortMidi uma solução mais simples para usuários leigos.

Apesar de teoricamente o JACK MIDI possuir uma melhor sincronização, em nossas medições constatamos que muitas aplicações que utilizam esta API não implementam corretamente a sincronização de eventos no interior de um bloco de áudio. Em nossos testes apenas interfaces firewire com driver FFADO apresentaram este nível de sincronização. Entretanto, muitas interfaces MIDI utilizam conexões USB e estão disponíveis no Linux apenas através do driver ALSA.

Em nossos testes de latência, o ALSA MIDI apresentou o melhor desempenho. Este conector é a API mais utilizada para o desenvolvimento de aplicações MIDI em Linux. Independentemente do resultado ter sido mais satisfatório, este conector existe exclusivamente no Linux e sua implementação não pode ser portada para outros sistemas operacionais. Por esta razão, esta API não atende aos critérios de portabilidade requerido para aplicações Medusa sendo o Portimidi uma solução de portabilidade para este tipo de dado.

\subsection{Avaliação dos Conectores de Áudio}

A avaliação dos conectores de áudio não pode ser feita nos mesmos moldes da avaliação dos conectores MIDI ou dos protocolos de rede, devido à dependência da latência em relação à frequência de amostragem e ao tamanho do bloco de amostras, correspondentes ao processo de enjanelamento 
do sinal. Desta maneira, é possível configurar a latência do sinal de áudio nos conectores escolhendo diferentes taxas de amostragem ou diferentes tamanhos de janelas.

Por esta razão, a avaliação dos conectores de áudio será feita a partir dos requisitos para o desenvolvimento da ferramenta, mapeados a partir das características desejáveis expostas no Capítulo 2.

\section{LADSPA}

A API LADSPA é definida por um arquivo cabeçalho (ladspa.h) e é bastante simples. Por razão desta simplicidade, os parâmetros de configuração de um plugin LADSPA permitem como parâmetros apenas valores numéricos representados em ponto flutuante de 32 bits. No caso da Medusa, isto tornou-se um empecilho para a representação de endereços IP, exigindo o uso de quatro controles separados para este fim, conforme apresentado na Figura 5.5.

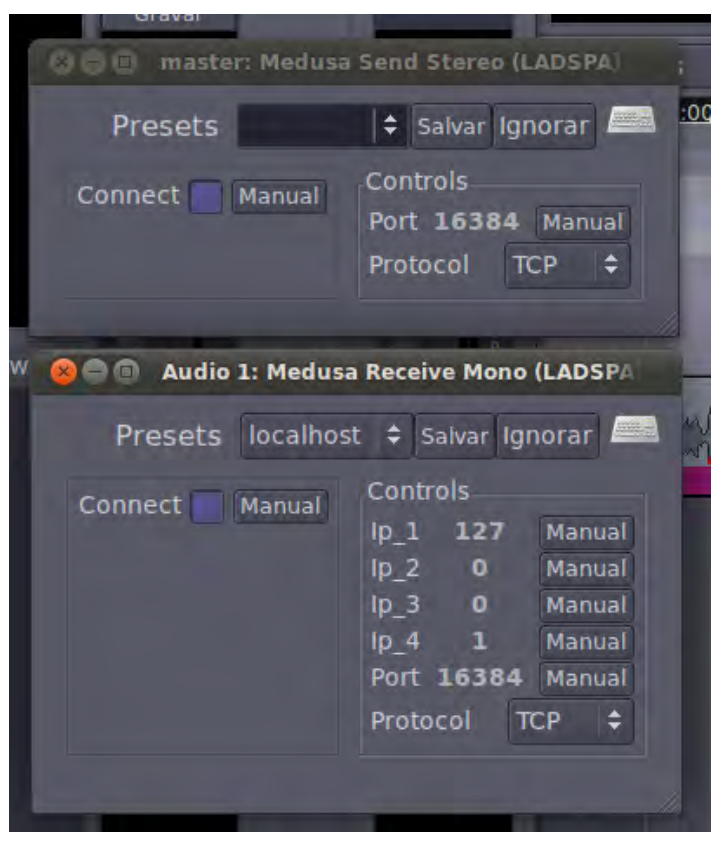

Figura 5.5: Implementação da Medusa em LADSPA.

Além desta limitação dos parâmetros de configuração do plugin, esta API não permite o desenvolvimento de interfaces gráficas. A definição da GUI de um plugin LADSPA é feita por meio de um arquivo XML no formato RDF, sendo que este arquivo traz apenas dicas para que o hospedeiro do plugin construa sua GUI. O uso deste arquivo RDF impede que a GUI seja alterada em tempo de execução, o que dificulta a utilização de nomes significativos na conexão dos recursos.

Além disto, não é possível bloquear os componentes de interface para impedir, por exemplo, que o usuário altere o endereço IP após a conexão ter sido estabelecida.

\section{LV2}

A API LV2, sucessora do LADSPA, possui também um descritor RDF em Turtle, porém, esta API permite que seja definida uma GUI em Qt ou GTK, trazendo melhores soluções de transparência no uso do LV2. As mudanças da GUI em tempo de execução permitem a conexão utilizando nomes significativos ao invés de endereços IP e números de porta. A dependência das bibliotecas GTK ou Qt não se configuram um empecilho para a utilização desta API de plugin, dada a popularidade e disponibilidade destas bibliotecas em várias plataformas. 


\section{Pure Data External}

O Pure Data [Puc96] (conhecido como PD) é um ambiente de programação gráfica em tempo real amplamente utilizado para o processamento de áudio e vídeo, que pode ser estendido por meio de externals escritos em $\mathrm{C} / \mathrm{C}++$. $\mathrm{O}$ PD possui alguns objetos que permitem a comunicação em rede, mas nenhum destes permite o uso de todos os protocolos de comunicação existentes na Medusa. Além disto, as técnicas de adaptação de um sinal heterogêneo aqui listadas também não são contempladas nas implementações dos externals para PD disponíveis para a transmissão de áudio.

Além de externals para o envio e recebimento de áudio, foi implementado no PD um external para o monitoramento do ambiente Medusa e para o envio e recebimento de mensagens de chat. Apesar de o PD não possuir um tipo de mensagem MIDI definida, ele possui interação com controladores MIDI e pode ser utilizado para integrar também este tipo de dados.

\section{JACK}

Esta API apresentou-se como uma alternativa multiplataforma para o envio de mensagens de áudio e MIDI com possibilidades ainda maiores de integração pela definição de mensagens de controle.

Como uma aplicação para o JACK não prevê qualquer tipo de UI, o desenvolvimento para esta API de som inclui o desenvolvimento de interfaces gráficas. Esta UI pode ser integrada com o monitoramento do ambiente e simplificar a transparência de configuração de conexões.

\section{ALSA Áudio}

Apesar dos bons resultados alcançados com a API ALSA MIDI para conexões MIDI, a API ALSA áudio se mostrou o conector mais limitado para o desenvolvimento da Medusa. Uma aplicação ALSA se conecta diretamente a um dispositivo de som do computador e depende da implementação do driver deste dispositivo. Por esta razão, a capacidade de cada dispositivo limita a configuração de aplicações sobre ele.

Ao instanciar a aplicação é necessário verificar a taxa de amostragem máxima que o dispositivo suporta, tamanho máximo de bloco, formato das amostras e se o dispositivo suporta ou não áudio não-entrelaçado. Além disto, a quantidade de canais é limitada pelas entradas e saídas físicas do dispositivo.

Por isto, não é possível trabalhar com um formato de áudio padrão, como o formato do JACK em 32 bits float, sem que a conversão entre formatos seja implementada dentro da aplicação.

Outra limitação desta API é o fato da mesma não ser multiplataforma, o que torna impossível portar uma aplicação construída sobre este conector para outro sistema operacional.

\section{PortAudio}

O PortAudio, como o PortMidi, permite que aplicações se conectem diretamente com dispositivos físicos da máquina. Além disto, o PortAudio também lista dispositivos virtuais do JACK e permite que estes dispositivos virtuais sejam utilizados na conexão.

Apesar desta API ser implementada sobre a API nativa do sistema operacional, ela oferece uma camada de abstração que permite a configuração de recursos de acordo com a necessidade da aplicação. Por isto, diferentemente do que ocorre com o ALSA áudio, é possível utilizar sempre áudio 32 bits em canais não-entrelaçados.

Como o ALSA, a quantidade de canais é limitada pela capacidade disponível no dispositivo físico, não sendo possível utilizar canais virtuais. Como o JACK e o ALSA, este conector não define interfaces para o usuário; interfaces podem ser construídas integrando o controle do ambiente. 


\section{Comparação Teórica dos Conectores de Áudio}

As APIs de áudio escolhidas até o momento para as implementações da Medusa não são facilmente comparáveis entre si, pois operam em diferentes camadas da arquitetura de som do computador. Algumas características comparáveis são apresentadas na Tabela 5.10.

Tabela 5.10: Comparação Teórica dos Conectores de Áudio

\begin{tabular}{lcccc}
\hline Conector & Canais & UI & Configuração do áudio & Multiplataforma \\
\hline LADSPA & 1 ou 2 & Depende do host & Depende do host & Não \\
LV2 & 1 ou 2 & GTL ou Qt & Depende do host & Não \\
PD & Configurável & Tcl / Tk & Configurável & Sim \\
JACK & Configurável & Não definida & Configurável & Sim \\
PortAudio & Depende do hw & Não definida & Configurável & Sim \\
ALSA áudio & Depende do hw & Não definida & Depende do hw & Não \\
\hline
\end{tabular}

Os plugins LADSPA e LV2 podem ser implementados e instanciados no modo Mono ou Estéreo. Já o PD e o JACK não possuem limitações quanto à quantidade de canais, pois utilizam canais virtuais internos à ferramenta que podem ser conectados a outros canais virtuais. Já as APIs PortAudio e ALSA áudio dependem da quantidade de canais do dispositivo utilizado no recebimento / envio.

A não existência de UI no plugin LADSPA dificulta a configuração de recebimento por meio do nome do recurso no ambiente. Já os demais conectores podem ser adequados a GUIs ou UIs de maneira simples.

A configuração de áudio nos plugins LADSPA e LV2 dependem da configuração do host e não da configuração do plugin. Como vários hosts permitem alterar a configuração de áudio, tal dependência não compromete a flexibilidade destas implementações; já as aplicações para JACK dependem da configuração do JACK, que é flexível. O Portaudio fornece um encapsulamento do dispositivo de som que permite ao programador definir configurações de áudio além daquelas que o dispositivo físico suporta. Já o ALSA depende diretamente do dispositivo e tem por padrão uma configuração de amostras de 16 bits em canais entrelaçados.

\subsubsection{Discussão}

A opção de implementar protótipos da Medusa com diferentes conectores de som veio da intenção de integrar este ambiente a diferentes ferramentas computacionais. Cada tipo de ferramenta de computação e música pode ser associado, ainda que indiretamente, a um perfil de usuário que utiliza computadores em diferentes processos musicais.

Os plugins LADSPA e LV2, por exemplo, são comumente associados a gravações, mixagem e masterização, utilizando ferramentas multicanais como hospedeiros. Estas APIs são compatíveis com ferramentas como Audacity, Ardour e QTractor. Neste cenário de utilização, o envio para a rede pode ser utilizado no monitoramento de uma gravação, para captação de fluxos distribuídos ou para o processamento remoto de efeitos, por exemplo. Apesar de mais ferramentas hospedeiras serem compatíveis com o plugin LADSPA, a configuração deste plugin não atendeu os requisitos necessários de usabilidade e configuração que buscamos na Medusa. Esta dificuldade para configuração sugere que seja disponibilizado no ambiente uma maneira de configurar sender e receiver de maneira remota, como, por exemplo a abordagem utilizada em [Lag04] para configurações complexas desta mesma API de plugins.

Já o ambiente Pure Data é muito utilizado em composição, espacialização, apresentações de música ao vivo, sound design e outros tipos de processamentos sonoros. Tal ferramenta vai de encontro ao cenário de performance e exploração de novas possibilidades musicais utilizando redes, pois já possui nativamente implementações para comunicação de mensagens de controle em rede. 
A implementação do conector de som com o servidor JACK é mais flexível, pois este servidor pode ser utilizado tanto por ferramentas de gravação quanto para performances musicais. No entanto, como a configuração deste servidor pode não ser simples para usuários leigos, esta implementação da Medusa busca atender usuários mais experientes, familiarizados com este servidor.

Já usuários que não utilizam ferramentas de gravações e plugins, não são usuários de Pure Data e não utilizam o servidor JACK, podem utilizar a Medusa diretamente com o dispositivo de áudio. Tal possibilidade é oferecida através da implementação do conector de som com o Portaudio. Esta implementação limita-se ao envio da entrada de microfone e o recebimento de dados da rede na saída de som do computador, um contexto de aplicação bastante limitado mas que pode satisfazer usuários menos experientes em busca, por exemplo, de uma ferramenta para ensaios musicais distribuídos. 


\section{Capítulo 6}

\section{Conclusão}

O desenvolvimento de uma ferramenta para música em rede se mostrou um campo de trabalho complexo, por envolver conhecimento de áreas distintas da computação, tais como computação musical, redes de computadores, engenharia de software, processamento de sinais e sistemas distribuídos, que são aplicados em um contexto artístico-musical que nem sempre permite uma avaliação objetiva dos resultados alcançados. O público alvo de tal ferramenta constitui-se de músicos, engenheiros de som e compositores, usuários estes que possuem necessidades específicas para seus cenários de aplicação, e que veem na computação a possibilidade de soluções que atendam a estas necessidades.

Durante o período de desenvolvimento deste trabalho tivemos a oportunidade de desenvolver colaborações com artistas e músicos interessados em adotar ferramentas de rede em suas obras. A proximidade com estes músicos ajudou a entender o processo de criação artístico-musical, a testar ferramentas existentes e participar ativamente deste processo, nos permitindo propor soluções para problemas específicos e analisar as dificuldades e benefícios encontrados na utilização de rede em música. Esta interação com músicos serviu de base para a pesquisa e análise das ferramentas relacionadas a este trabalho.

Esta exploração mostrou que várias soluções anteriores foram implementadas com o intuito de permitir conexões musicais em rede em cenários específicos onde estas ferramentas foram idealizadas, cenários estes que serviram de motivação para o desenvolvimento, mas que também explicam as limitações existentes em cada ferramenta e as soluções encontradas por seus autores para problemas recorrentes em cada cenário específico.

Indo além das soluções encontradas nas ferramentas relacionadas, nossa pesquisa envolvendo o desenvolvimento de aplicações musicais para redes mostrou soluções alternativas, que podem ser empregadas neste domínio específico, utilizando para isto características de diferentes protocolos de rede e diferentes modos de endereçamento, como confirmações de recebimento de pacotes e controle de congestionamento, que se traduzem em características de interesse musical direto, tais como latência, jitter e perda de pacotes. Tais características foram mensuradas na Seção de avaliação e podem servir de guia para o usuário ao configurar a ferramenta aqui desenvolvida para suas necessidades específicas em função do cenário de aplicação desejado.

Nossa pesquisa sobre o desenvolvimento de aplicações musicais incluiu uma classificação dos conectores de som em uma arquitetura em camadas, sugerindo a utilização de conectores distintos para a integração de ferramentas às aplicações existentes. Este estudo, que permitiu a implementação da Medusa utilizando estas APIs, proporcionou também a criação de um manual ${ }^{1}$ para o desenvolvimento de externals para Pure Data, bem como o desenvolvimento de uma ferramenta para geração automática de códigos de externals Pd a partir de uma especificação flexível ${ }^{2}$. Também foi desenvolvido um gerador de códigos para plugins LADSPA ${ }^{3}$ que ajudou no desenvolvimento de

\footnotetext{
${ }^{1}$ Disponível em: https://github.com/flschiavoni/pd-external-tutorial. Acessada em 01/12/2013.

${ }^{2}$ Disponível em: http://www.ime.usp.br/ fls/PDExternal-generator/PDExternal_generator.html. Acessada em $01 / 12 / 2013$.

${ }^{3}$ Disponível em: http://www.ime.usp.br/ fls/LADSPA-generator/LADSPA_generator.html. Acessada em $01 / 12 / 2013$.
} 
uma biblioteca de plugins para processamento de efeitos de áudio ${ }^{4}$ em colaboração com colegas do grupo de pesquisa em computação musical do IME-USP ${ }^{5}$.

O mapeamento de cenários distintos de uso das ferramentas de música em rede inspirou a proposição de um conjunto de características desejáveis em uma ferramenta que atenda às necessidades específicas de usuários em contextos musicais diferentes. O mapeamento destes cenários e necessidades ajuda a esclarecer as possibilidades de uso para a música em rede, e teve grande importância no desenvolvimento deste trabalho.

Após o mapeamento das características desejáveis, este trabalho apresentou uma proposta arquitetural para o desenvolvimento da ferramenta, utilizando para isto conceitos de engenharia de software, como a arquitetura em camadas, e de sistemas distribuídos, como a publicação de serviços e recursos. A proposta arquitetural expandiu a solução trivial para a comunicação de fluxos de áudio apresentada na introdução deste trabalho, dissecando cada uma de suas partes e propondo soluções para problemas conhecidos.

Findadas as discussões arquiteturais, as implementações da ferramenta foram abordadas. Nestas implementações, as camadas propostas na visão arquitetural foram abordadas e dentro de cada camada, os componentes necessários foram explicitados. As implementações apresentam resultados para alguns objetivos propostos, como a utilização de vários conectores de som para uma integração mais abrangente das ferramentas desenvolvidas com aplicações já existentes. O estágio atual de desenvolvimento permite expandir ainda mais este conjunto de APIs sem que seja necessário alterar a ferramenta, já que a arquitetura em camadas foi implementada por meio da biblioteca libmedusa, que permite o uso das camadas de controle e rede por qualquer conector de som desejado, de maneira simples e transparente para o programador/desenvolvedor.

As aplicações desenvolvidas sobre a libmedusa foram utilizadas como prova de conceito e permitiram a avaliação das soluções encontradas. Tais avaliações apresentaram os limites de latência na utilização da ferramenta em diferentes conexões de rede e trazem resultados que podem auxiliar o usuário na configuração de seu ambiente.

A usabilidade, um dos objetivos iniciais do desenvolvimento deste trabalho, guiou a simplificação da utilização da ferramenta em diversos sentidos, como a transparência de localização e de configuração através da publicação de recursos, a visão do ambiente como um todo através de interfaces de monitoramento, e a utilização da ferramenta dentro de aplicações existentes (através de plugins e externals).

Finalmente, este trabalho trouxe como resultado não apenas um conjunto de ferramentas interoperáveis para música em rede e uma biblioteca para o desenvolvimento de novas ferramentas, mas também parcerias em peças musicais baseadas em música em rede e a difusão do conhecimento adquirido através da publicação de artigos, participação em conferências e realizações de oficinas para práticas de músicas em rede.

Entre as peças musicais baseadas em rede em que pudemos participar estão as parcerias e colaboração com o Duo N-1 ${ }^{6}$ nas peças "Marulho trans-oceânico", "Metaremix", e "Surfing on turntables". A primeira peça utiliza uma conexão transoceânica entre artistas localizados no Brasil e na Alemanha, sendo que o seu processo de desenvolvimento e resultado foi publicado em [OFS13]. As duas outras peças utilizam conexões em rede local.

Com o artista Giuliano Obici ${ }^{7}$ colaboramos nas peças "Concerto pra lanhouse", "Laptop choral" e "Simulacrum chamber orquestra", todas utilizando redes locais.

Com o artista André Damião Bandeira ${ }^{8}$, colaboramos na configuração de uma instalação de vídeo mapping chamada "Tirando de Letra", com quatro computadores conectados em rede local. A parceria com este artista rendeu outros trabalhos através do desenvolvimento de externals para Pure Data.

\footnotetext{
${ }^{4}$ Disponível em: http://sourceforge.net/projects/jaimeffects/. Acessada em 01/12/2013.

${ }^{5}$ http://compmus.ime.usp.br/ Acessada em 01/12/2013.

${ }^{6}$ http://n-1.art.br/ Acessada em 01/12/2013.

${ }^{7}$ http://giulianobici.com/site/inicio.html Acessada em 01/12/2013.

${ }^{8}$ http://andredamiao.hotglue.me/ Acessada em 01/12/2013.
} 
Com o artista russo-canadense Egor Sanin, colaboramos na criação de uma instalação chamada "Echos". Esta instalação utiliza a rede de uma maneira bastante diferente e baseia-se em uma aplicação chamada "Honky Conky"9 que utiliza cabeçalhos de pacotes de rede como interface musical.

Quanto à difusão do conhecimento, foram publicados ao todo 10 artigos, sendo 6 deles em encontros internacionais e 4 deles em encontros nacionais. São eles "Medusa - A Distributed Sound Environment" [SQI11], "Concerto para Lanhouse" [OS11a], "Heterogeneidade e Transparência em Network Music" [Sch11], "Lanhouse Concert" [OS11b], "Network distribution in music applications with Medusa" [SQ12], "Ferramentas livres para distribuição de áudio em rede" [SQB12], "APIs para o desenvolvimento de aplicações de áudio" [SGQ12], "Alternatives In Network Transport Protocols For Audio Streaming Applications" [SQW13a], "Network Music With Medusa: A Comparison Of Tempo Alignment In Existing MIDI Apis" [SQW13b], "Marulho TransOceânico: performance musical entre dois continentes" [OFS13].

Além da publicação de artigos, fizemos parte da organização do simpósio internacional multisítios "Net-Music 2013: The Internet as Creative Resource in Music" ${ }^{10}$. O evento contou com a participação de várias universidades e centros de pesquisa e tinha caráter telemático e distribuído, com apresentações em vários locais.

Duas oficinas de difusão científico-cultural foram realizadas no âmbito do tema desta tese. Em 29 de Abril de 2013 foi realizado juntamente com o artista Pedro Henrique de Faria um workshop sobre a utilização de redes em performances musicais, no laboratório IDML do Departamento de música e tecnologia da Universidade McGill (Montreal - Canadá). Focando o desenvolvimento de práticas musicais distribuídas, este workshop reuniu cerca de 12 alunos deste e de outros laboratórios que compõem o departamento de música e tecnologia da Mcgill. Outra oficina foi realizada em 24 de Junho de 2013 no Departamento de Música da Escola de Comunicação e Artes da Universidade de São Paulo, focando o mesmo tipo de desenvolvimento. Este evento contou com a participação de cerca de 10 alunos e professores que fazem parte do grupo de pesquisa em Sonologia da USP.

\subsection{Trabalhos Futuros}

A ferramenta em seu estágio atual possui algumas limitações, tais como:

- A utilização da ferramenta desenvolvida em uma rede doméstica ADSL ainda depende da configuração de portas NAT no roteador, conforme explicado no Capítulo 2 deste documento.

- Apesar da preocupação com o uso de APIs multiplataforma, não foram feitos testes de compilação do código-fonte atual em outros sistemas operacionais além do Linux.

A limitação sobre a utilização da Medusa em conexões domésticas pode ser resolvida com a utilização da técnica de hole punching, apresentada no Capítulo 2 deste trabalho. Um protótipo deste modelo de comunicação foi desenvolvido ${ }^{11}$ para o envio de mensagens do Pure Data e alguns testes iniciais foram realizados. A integração desta técnica na Medusa eliminará esta limitação.

Outros protocolos de rede foram propostos durante a implementação deste trabalho, trazendo novas possibilidades de comunicação em rede. Um exemplo deste protocolo é uma variação do TCP, chamado MPTCP [FRHB13], que funciona de maneira similar ao SCTP e permite endereçamentos múltiplos de pacotes. Pretendemos testar e avaliar a implementação da comunicação da Medusa sobre este protocolo.

As mensagens da Medusa foram empacotadas em um formato de rede de maneira a utilizar o menor cabeçalho possível, mantendo o alinhamento (em bytes) das estruturas e a compatibilidade das mensagens para plataformas distintas. A possibilidade de empacotarmos mensagens utilizando o formato OSC pode ampliar a integração da Medusa com outras ferramentas existentes. Como

\footnotetext{
${ }^{9}$ Disponível em http://sourceforge.net/projects/honkyconky/. Acessada em 01/12/2013.

${ }^{10}$ http://netmusic2013.wordpress.com/ Acessada em 01/12/2013.

${ }^{11}$ Disponível em: http://sourceforge.net/projects/pdholepunch/. Acessada em 01/12/2013.
} 
o empacotamento de mensagens no formato OSC pode ser significativamente maior que o implementado atualmente, existe a possibilidade de mantermos os dois formatos e deixar ao usuário a escolha sobre a configuração do formato das mensagens.

$\mathrm{Na}$ arquitetura proposta foram apresentadas possibilidades de mensagens da camada de aplicação que permitiriam uma integração maior do ambiente com os conectores de som. Tais mensagens ainda não implementadas no ambiente e a integração destas mensagens também é parte dos trabalhos futuros.

As ferramentas desenvolvidas permitem que o ambiente integre diferentes conectores de som devido à padronização das mensagens e tipos de dados do ambiente. Esta padronização existente na implementação deverá ser documentada através da especificação de um protocolo de aplicação Medusa. Tal especificação de protocolo será fundamental para guiar o desenvolvimento de outras aplicações, em outras linguagens de programação, mas compatíveis com a ferramenta atual. 


\section{Referências Bibliográficas}

[Ana09] Ilias Anagnostopoulos. The otherside web-based collaborative multimedia system. Em LAC, editor, Proceedings of the Linux Audio Conference, páginas 131-137, 2009. 5,8

[ATIQ13] Julian Jaramillo Arango, Marcio Tomiyoshi, Fernando Iazzetta e Marcelo Queiroz. Brazilian challenges on network music. Em Proceedings of the Sound and Music Computing Conference 2013, páginas 453-460, Stockholm, Sweden, 2013. 1, 32

[BE07] Horia Vlad Balan e Lars Eggert. An experimental evaluation of voice quality over the datagram congestion control protocol. Em Proc. IEEE INFOCOM 200\%, páginas 6-12, 2007. 23

[BG96] Jean-Chrysostome Bolot e Andrés Vega García. Control mechanisms for packet audio in the internet. Em INFOCOM '96. Fifteenth Annual Joint Conference of the IEEE Computer Societies. Networking the Next Generation. Proceedings IEEE, páginas 232 - 239 vol.1, 1996. 28,34

$\left[\mathrm{BUB}^{+} 08\right]$ Saleem Bhatti, Fife Ky Sx Uk, Martin Bateman, Fife Ky Sx Uk e Dimitris Miras. A comparative performance evaluation of dccp. Em In Proc. Int. Sym. on Performance Evaluation of Computer and Telecommunication Systems (SPECTS2008), 2008. 24

[CC09a] Juan-Pablo Cáceres e Chris Chafe. Jacktrip: Under the hood of an engine for network audio. Em Proceedings of International Computer Music Conference, página 509-512, San Francisco, California: International Computer Music Association, 2009. 5

[CC09b] "Juan-Pablo Cáceres"e "Chris Chafe". Jacktrip/Soundwire meets server farm. Em In Proceedings of the SMC 2009 - 6th Sound and Music Computing Conference, páginas 95-98, Porto, Portugal, 2009. 5

[CGLT04] Chris Chafe, Michael Gurevich, Grace Leslie e Sean Tyan. Effect of time delay on ensemble accuracy. Em In Proceedings of the International Symposium on Musical Acoustics, 2004. 30

[Cha11] Chris Chafe. Living with net lag. Em Proceedings of AES 43RD INTERNATIONAL CONFERENCE, Pohang, Korea, 2011. 1, 5

[CHW09] A. Carôt, T. Hohn e C. Werner. Netjack-remote music collaboration with electronic sequencers on the internet. Em Proceedings of the Linux Audio Conference, páginas 118 - 122, Parma, Italy, 2009. 6

[CKS06] A. Carôt, U. Kramer e G. Schuller. Network music performance (NMP) in narrow band networks. Em Proceedings of the 120th AES Convention, Paris, France, 2006. $1,10,30$

[Com00] Douglas E. Comer. Internetworking with TCP/IP Vol.1: Principles, Protocols, and Architecture (4th Edition). Prentice Hall, 2000. 19, 20 
[CRV06] Alexander Carôt, Alain Renaud e Bruno Verbrugghe. Network Music Performance (NMP) with Soundjack. Em In Proceedings of NIME 2006 Network Performance Workshop, 2006. 1, 10

[CRW08] Alexander Carôt, Alain B. Renaud e Christian Werner. Audible icmp echo responses for monitoring ultra low delayed audio streams. Em AES 124th Convention, Amsterdam, The Netherlands, 5 2008. 10

[CVM10] M. Cotton, L. Vegoda e D. Meyer. IANA Guidelines for IPv4 Multicast Address Assignments. RFC 5771 (Best Current Practice), Março 2010. 26

[CW08] Alexander Carôt e Christian Werner. Distributed network music workshop with soundjack. Em In proceedings of the Tonmeistertagung, Leipzig, Germany, 2008. 10

[CW09] Alexander Carôt e Christian Werner. External latency-optimized soundcard synchronization for applications in wide-area networks. Em AES 14th Regional Convention, Tokio, Japan, 7 2009. 10

$\left[\mathrm{CWL}^{+} 00\right]$ Chris Chafe, Scott Wilson, Al Leistikow, Dave Chisholm e Gary Scavone. A simplified approach to high quality music and sound over IP. Em In Proceedings of the COST G-6 Conference on Digital Audio Effects (DAFX-00, páginas 159-164, 2000. 30, 34

[DC09] Michael J. Donahoo e Kenneth L. Calvert. TCP/IP Sockets in C Bundle: TCP/IP Sockets in C, Second Edition: Practical Guide for Programmers (Morgan Kaufmann Practical Guides). Morgan Kaufmann, 2009. 20, 38

[DJCdMB11] Elias P. Duarte Jr., Kleber V. Cardoso, Micael O. M. C. de Mello e Joao G. G. Borges. Transparent communications for applications behind nat/firewall over any transport protocol. Em Proceedings of the 2011 IEEE 17th International Conference on Parallel and Distributed Systems, ICPADS '11, páginas 935-940, Washington, DC, USA, 2011. IEEE Computer Society. 27

[EF94] K. Egevang e P. Francis. The IP Network Address Translator (NAT). RFC 1631 (Informational), Maio 1994. Obsoleted by RFC 3022. 26

[FRHB13] A. Ford, C. Raiciu, M. Handley e O. Bonaventure. TCP Extensions for Multipath Operation with Multiple Addresses. RFC 6824 (Experimental), Janeiro 2013. 91

[FSK05] Bryan Ford, Pyda Srisuresh e Dan Kegel. Peer-to-peer communication across network address translators. Em Proceedings of the annual conference on USENIX Annual Technical Conference, ATEC '05, páginas 13-13, Berkeley, CA, USA, 2005. USENIX Association. 27, 28

[GS96] Audio-Video Transport Working Group e H. Schulzrinne. RTP Profile for Audio and Video Conferences with Minimal Control. RFC 1890 (Proposed Standard), Janeiro 1996. Obsoleted by RFC 3551. 24

[Haj03] Georg Hajdu. Quintet.net - a quintet on the internet. Em Proceedings of International Computer Music Conference, página 315-318, Singapore, 2003. 5

[HD06] R. Hinden e S. Deering. IP Version 6 Addressing Architecture. RFC 4291 (Draft Standard), Fevereiro 2006. Updated by RFCs 5952, 6052. 26

[HP08] Hewlett-Packard. SCTP Programmer's Guide. Hewlett-Packard Development Company, 2008. ix, 22

[HS01] M. Holdrege e P. Srisuresh. Protocol Complications with the IP Network Address Translator. RFC 3027 (Informational), Janeiro 2001. 27, 28 
[Iaz10] Fernando Iazzetta. Música e mediação tecnológica. Perspectiva, São Paulo - Brazil, 2010. 1

[KHF03] "Eddie Kohler, Mark Handley"e Sally Floyd. Designing dccp: Congestion control without reliability, 2003. ix, 23, 24

[KHF06] E. Kohler, M. Handley e S. Floyd. Datagram Congestion Control Protocol (DCCP). RFC 4340 (Proposed Standard), Março 2006. Updated by RFCs 5595, 5596, 6335, 6773. 23

[KI98] Fabio Kon e Fernando Iazzetta. Internet music: Dream or (virtual) reality? Em In Proceedings of the 5th Brazilian Symposium on Computer Music, páginas 69-81, 1998. 29

[KR00] James F. Kurose e Keith W. Ross. Computer Networking: A Top-Down Approach Featuring the Internet. Addison Wesley Publishing Company, 2000. ix, 19, 20, 21, 22

[Lag04] Nelson Posse Lago. Processamento distribuído de áudio em tempo real. Dissertação (mestrado em ciência da computação), Instituto de Matemática e Estatística, Universidade de São Paulo, São Paulo - Brazil, 2004. 86

[LAM09] Stéphane Letz, Nedko Arnaudov e Romain Moret. What's new in JACK2? Em LAC, editor, Proceedings of the Linux Audio Conference, páginas 1-9, Parma, Italy, 2009. 1,6

[LK04] Nelson Posse Lago e Fabio Kon. The quest for low latency. Em Proceedings of the International COmputer Music Conference (ICMC2004), páginas 33-36, 2004. 29, 30

[LK05] Junwen Lai e Eddie Kohler. A congestion-controlled unreliable datagram api. http://www.icir.org/kohler/dccp/ nsdiabstract.pdf, 2005. 23

[Loy85] Gareth Loy. Musicians make a standard: The MIDI phenomenon. Computer Music Journal, 9(4):pp. 8-26, 1985. 16

[LW01] John Lazzaro e John Wawrzynek. A case for network musical performance. Em Proceedings of the 11th international workshop on Network and operating systems support for digital audio and video, NOSSDAV '01, páginas 157-166, New York, NY, USA, 2001. ACM. 30

[MID08] MIDI Manufacturers Association. White paper: Comparison of MIDI and OSC. http://www.midi.org/aboutmidi/midi-osc.php, Novembro 2008. 78

[Mog84] J.C. Mogul. Broadcasting Internet Datagrams. RFC 919 (INTERNET STANDARD), Outubro 1984. 26

[Moo90] F. Richard Moore. Elements of computer music. Prentice-Hall, Inc., Upper Saddle River, NJ, USA, 1990. 13

[MRKS01] K. Morneault, S. Rengasami, M. Kalla e G. Sidebottom. ISDN Q.921-User Adaptation Layer. RFC 3057 (Proposed Standard), Fevereiro 2001. Obsoleted by RFC 4233, updated by RFC 3807. 27

[MSW08] Joseph Malloch, Stephen Sinclair e Marcelo M. Wanderley. Computer music modeling and retrieval. sense of sounds. chapter A Network-Based Framework for Collaborative Development and Performance of Digital Musical Instruments, páginas 401-425. Springer-Verlag, Berlin, Heidelberg, 2008. 26 
[NT04] Mark Nelson e Belinda Thom. A survey of real-time MIDI performance. Em Proceedings of the 2004 conference on New interfaces for musical expression, NIME '04, páginas 35-38, Singapore, Singapore, 2004. National University of Singapore. 16

[OFS13] Giuliano Lambert Obici, Alexandre Fenerich e Flávio Luiz Schiavoni. Marulho transoceânico: performance musical entre dois continentes. Em SBCM 2013, Brasília DF - Brazil, aug-sep 2013. 32, 90, 91

[OS11a] Giuliano Lambert Obici e Flávio Luiz Schiavoni. Concerto para lanhouse. Em Proceedings of the Linux Audio Conference, páginas 170-174, Maynooth, Ireland, 2011. 32, 91

[OS11b] Giuliano Lambert Obici e Flávio Luiz Schiavoni. Lanhouse concert. Em Proceedings of Pure Data Conference, Weimar / Berlin, Germany, 2011. 32, 91

$\left[\mathrm{PBD}^{+} 06\right]$ Lydia Parziale, David T. Britt, Chuck Davis, Jason Forrester e Wei Liu. TCP/IP Tutorial and Technical Overview. Vervante, 2006. 19, 20, 23

[PD03] Larry L. Peterson e Bruce S. Davie. Computer Networks, Third Edition: A Systems Approach, 3rd Edition (The Morgan Kaufmann Series in Networking). Morgan Kaufmann, 2003. 20, 21, 22

[Puc96] Miller Puckette. Pure data: another integrated computer music environment. Em in Proceedings, International Computer Music Conference, páginas 37-41, 1996. 85

$\left[\mathrm{RMK}^{+}\right.$96] Y. Rekhter, B. Moskowitz, D. Karrenberg, G. J. de Groot e E. Lear. Address Allocation for Private Internets. RFC 1918 (Best Current Practice), Fevereiro 1996. Updated by RFC 6761.26

[RWHM03] J. Rosenberg, J. Weinberger, C. Huitema e R. Mahy. STUN - Simple Traversal of User Datagram Protocol (UDP) Through Network Address Translators (NATs). RFC 3489 (Proposed Standard), Março 2003. Obsoleted by RFC 5389. 27, 28

[Sch11] Flávio Luiz Schiavoni. Heterogeneidade e transparência em network music. Em SBCM 2011, Vitória - ES - Brazil, aug 2011. 24, 91

[SE01] P. Srisuresh e K. Egevang. Traditional IP Network Address Translator (Traditional NAT). RFC 3022 (Informational), Janeiro 2001. 27

[Sen02] D. Senie. Network Address Translator (NAT)-Friendly Application Design Guidelines. RFC 3235 (Informational), Janeiro 2002. 27

[SFK08] P. Srisuresh, B. Ford e D. Kegel. State of Peer-to-Peer (P2P) Communication across Network Address Translators (NATs). RFC 5128 (Informational), Março 2008. 28

[SFR03] W. Richard Stevens, Bill Fenner e Andrew M. Rudoff. Unix Network Programming, Volume 1: The Sockets Networking API (3rd Edition). Addison-Wesley Professional, 2003. $19,22,23$

[SFW10] Andrew Schmeder, Adrian Freed e David Wessel. Best practices for open sound control. Em Proceedings of the Linux Audio Conference, página 131, Utrecht, NL, 2010. 5,31

[SGQ12] Flávio Luiz Schiavoni, Antonio José Homsi Goulart e Marcelo Queiroz. APIs para o desenvolvimento de aplicações de áudio. Em Anais do IV Seminário Música Ciência Tecnologia, São Paulo, Brasil, 2012. 91

[SH99] P. Srisuresh e M. Holdrege. IP Network Address Translator (NAT) Terminology and Considerations. RFC 2663 (Informational), Agosto 1999. 27 
[SQ12] Flávio Luiz Schiavoni e Marcelo Queiroz. Network distribution in music applications with medusa. Em Proceedings of the Linux Audio Conference, páginas 9-14, Stanford, USA, 2012. 91

[SQB12] Flávio Luiz Schiavoni, Marcelo Queiroz e André Jucovsky Bianchi. Ferramentas livres para distribuição de áudio em rede. Em Anais do III Ubimus, São Paulo, Brasil, 2012. 18, 91

[SQI11] Flávio Luiz Schiavoni, Marcelo Queiroz e Fernando Iazzetta. Medusa - a distributed sound environment. Em Proceedings of the Linux Audio Conference, páginas 149156, Maynooth, Ireland, 2011. 91

[SQW13a] Flávio Luiz Schiavoni, Marcelo Queiroz e Marcelo Wanderley. Alternatives in network transport protocols for audio streaming applications. Em Proceedings of the International Computer Music Conference, Perth, Australia, 2013. 91

[SQW13b] Flávio Luiz Schiavoni, Marcelo Queiroz e Marcelo Wanderley. Network music with medusa: A comparison of tempo alignment in existing midi apis. Em Proceedings of the Sound and Music Computing Conference, Stockholm, Sweden, 2013. 91

[SRL98] H. Schulzrinne, A. Rao e R. Lanphier. Real Time Streaming Protocol (RTSP). RFC 2326 (Proposed Standard), Abril 1998. 24

[SS06] Asbjørn Sæbø e U. Peter Svensson. A low-latency full-duplex audio over IP streamer. Em Proceedings of the Linux Audio Conference, páginas 25-31, Karlsruhe, Germany, 2006. 5, 8, 30

[Ste94] W. Richard Stevens. TCP/IP Illustrated, Vol. 1: The Protocols (Addison-Wesley Professional Computing Series). Addison-Wesley Professional, 1994. ix, 19, 20, 21, 26

[Tan02] Andrew S. Tanenbaum. Computer Networks (4th Edition). Prentice Hall, 2002. 20, 22

[Tom13] Marcio Masaki Tomiyoshi. Performances musicais distribuídas através de internet residencial. Dissertação (mestrado em ciência da computação), Instituto de Matemática e Estatística, Universidade de São Paulo, São Paulo - Brazil, 2013. 6

[Win07] D. Wing. Symmetric RTP / RTP Control Protocol (RTCP). RFC 4961 (Best Current Practice), Julho 2007. 24

[Wri05] Matthew Wright. Open Sound Control: an enabling technology for musical networking. Organised Sound, 10:193-200, 2005. 5

[You01] John P. Young. Using the Web for live interactive music. Em Proceedings of International Computer Music Conference, páginas 302-305, Habana, Cuba, 2001. 34 